\title{
Country report for Cameroon
}

Christopher F. Tamasang (lead author), Cyril Effala (contributing author) \& Ivo T. Tassah (contributing author)

\section{Country information}

Often referred to as 'Africa in miniature' because of its geographical and cultural diversity, the Republic of Cameroon is one of the countries that make up the Central African Subregion, which is a political and economic unit.

\subsection{Geography and climatic conditions}

The Republic of Cameroon is geographically located within Central Africa. The country stretches from latitude $2^{\circ} \mathrm{N}$ to $13^{\circ} \mathrm{N}$ of the equator and $9^{\circ} \mathrm{E}$ and $16^{\circ} \mathrm{E}$ of the Greenwich Meridian. ${ }^{1}$ This location situates the country at the extreme north-eastern end of the Gulf of Guinea. It is bordered by the Federal Republic of Nigeria in the west, the Republic of Chad in the north, the Central African Republic in the east, and the Republic of Congo, Equatorial Guinea and Gabon in the south. ${ }^{2}$ Important boundary landmarks are Lake Chad in the north and the Atlantic Ocean in the south-west. Cameroon is strategically located in the Gulf of Guinea ${ }^{3}$ in the Central African Subregion and occupies a central position in the Economic and Monetary Community of Central African States (CEMAC). This geostrategic relevance of the country, coupled with the fact that it opens up to the Atlantic Ocean in the south-west, attracts many foreign investors for the exploitation of natural resources in particular, and trade in general. The country equally serves as a passageway for the landlocked countries of Chad, the Central African Republic and Congo Brazzaville for the importation and exportation of goods. As the meeting point of West and Central Africa at the heart of the Gulf of Guinea, Cameroon is the gateway to the economy of a part of Central Africa and a trade route between the economies of West and Central Africa. ${ }^{4}$ The region's only deepwater ports of Douala and Kribi play a decisive role in its economy.

Neba (1987: 2).

Yahmed et al. (2007: 18).

Ngoh (1996: 3).

Tajoche (2008: 12). 
Cameroon has a total surface area of $475,442 \mathrm{~km}^{2}$, which is divided into $472,710 \mathrm{~km}^{2}$ of total landmass and $2,730 \mathrm{~km}^{2}$ of water bodies. According to Neba, ${ }^{5}$ the country has the shape of a carelessly drawn triangle with a broad base measuring $888 \mathrm{~km}$ in the south and a narrow top in the north. ${ }^{6}$ The distance from the south to the north is about $1,221 \mathrm{~km}$.

Cameroon is located in the tropics where temperatures are generally high throughout the year for most parts of the country. ${ }^{7}$ Rainfall is heavy in the southern part of the country, especially around the coast of the Atlantic Ocean and the Western Highlands, and decreases from the south towards the northern part of the country. Two main seasons, namely the wet season and the dry season, are experienced in the country. Cameroon has two main climates: the equatorial climate and the tropical climate. ${ }^{8}$ The equatorial climatic type is experienced in the Equatorial Rainforest region in the southern part of the country between latitudes $2^{\circ}$ and $6^{\circ}$ north of the equator. It is felt mainly in the Coastal Lowland and the Southern Low Plateau which covers the Southwest, Littoral, Centre, South, and East Regions of the country. ${ }^{9}$ The equatorial climate is made up of two sub-types: the Cameroon type and the Guinean type. ${ }^{10}$ The Guinean type is experienced from the coast of Kribi to the Southern Low Plateau and is characterised by four seasons - two rainy seasons (in September and March-April) and two dry seasons (in December-January and July-August). ${ }^{11}$ The Cameroon type, induced by both maritime and relief, is experienced along the south-western coast around Mount Cameroon extending to the mouth of the River Sanaga and the limits of the Western Highlands. ${ }^{12}$ This sub-type has two main seasons - the rainy season and the dry season. ${ }^{13}$

The tropical climate is the second major type of climate in Cameroon and can be divided into two main sub-types: the humid tropical climate or the Sudan climate and the dry tropical climate or the Sahel climate. The humid tropical climate is common in the Western Highlands and Adamawa Plateau. The dry tropical climate is experienced in the Northern Lowlands which cover the North and Far North Regions of Cameroon. ${ }^{14}$

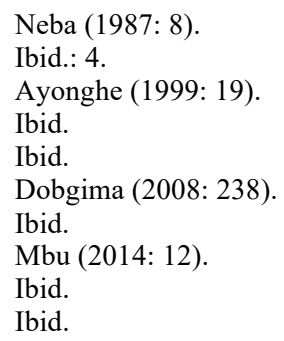




\subsection{Economy}

Cameroon is primarily an agro-based economy. Almost $70 \%$ of the population is engaged in agriculture and related activities. ${ }^{15}$ The economy is dominated by a primary sector involved in the exploitation of primary commodities destined for exportation with little or no processing. The industrial base that drives the secondary sector is highly limited. However, the service sector is increasing considerably especially in the face of rapid urbanisation in the country. It should be noted that the country's economy was one of the fastest growing economies in Africa for a quarter of the 20th century after Cameroon gained independence in $1961 .{ }^{16}$ However, a combination of factors such as a drop in the prices of export commodities such as petrol, coffee, cocoa and cotton alongside an overvalued currency and mismanagement led to an economic meltdown, giving rise to hardship and growing poverty. ${ }^{17}$ However, after the completion of the heavily indebted poor country initiative of the International Monetary Fund and based on the country's Growth and Employment Strategy Paper (GESP), there are hopes for the economy to bounce back onto a growth track, everything being equal. Cameroon's gross national product (GNP) for 2018 was estimated at US $\$ 36.37$ billion, a $10.66 \%$ increase from 2017. ${ }^{18}$ The country's GNP for 2017 was estimated at US $\$ 32.87$ billion, a $0.68 \%$ decline from $2016 .{ }^{19}$

Regarding its national debt over the first three months of 2019, Cameroon's public debt reached CFA F7,494 billion (i.e. franc of the African Financial Community ${ }^{20}$ ) (about $35 \%$ of gross domestic product (GDP)), according to MINFI. ${ }^{21}$ In 2018, outstanding debt was CFA F7,318 billion (34.4\% of GDP) against CFA F6,255 billion (30.8\% of GDP) in late $2017 .{ }^{22}$ However, the Autonomous Sinking Fund (Caisse Autonome d'Amortisement) - the organ in charge of public debt management in Cameroon - estimated the 2018 debt of Cameroon at CFA F6,527 billion. ${ }^{23}$ The debt increase is motivated by acceleration in big infrastructure projects. ${ }^{24}$

Foreign direct investments (FDI) inflow to Cameroon is usually low compared to the potential of its economy. FDI reached US\$672 million in 2017 and was stable compared to the previous year, according to the World Investment Report 2018 of the

\section{Tassah (2018: 3).}

16 Ngoh (2019: 2).

17 Mbu (2014: 21).

18 See macrotrends website on Cameroon GNP 1967-2019, at https://www.macrotrends.net/countries/CMR/cameroon/gnp-gross-national-product, accessed 3 October 2019.

19 Ibid.

20 Communauté Financière Africaine Franc.

21 See https://www.businessincameroon.com/finance/0705-9098-cameroon-public-debt-reachedxaf7-494bln-in-q1-2019-35-of-gdp, accessed 19 July 2019.

22 Ibid.

23 See Business in Cameroon website, at https://www.businessincameroon.com/economy/05078173-cameroon-s-debt-rose-to-cfa6-527-billion-by-may-31-2018, accessed 3 June 2019.

24 Ibid. 
United Nations Conference on Trade and Development. In 2018, FDI stocks were estimated to represent $21.9 \%$ of GDP (US\$6.4 billion; it was 19.8\% in 2016). Most of the FDI came from the European Union, particularly France and Germany, and targeted the mining industry, including oil extraction. However, China has become a major investor in the country, carrying on large infrastructure projects. China has been investing steadily in Cameroon (with the total Chinese direct and indirect investments amounting to US\$2.43 billion in 2016, according to the Cameroonian Ministry of Economy), allowing the construction of Kribi Port and Industrial Complex, Memve'ele Hydroelectric Dam, and new football stadiums. ${ }^{25}$

Cameroon's economy has the potential to become one of the most prosperous and best placed to receive FDI in Africa, ${ }^{26}$ which is why the country continues to seek foreign investment to improve its inadequate infrastructure, create jobs, and improve its economic footprint. However, its unfavourable business environment remains a significant deterrent to foreign investment. ${ }^{27}$ In addition to endemic corruption, lack of infrastructure, a risk of high political tension, and one of the highest tax burdens on the private sector in the world, Cameroon has a complicated business environment, as evidenced by its 163 rd place out of 190 in the Doing Business ranking of $2018 .^{28}$

\subsection{Society}

Available data on the total population of Cameroon and its distributions is contradictory. Different data are provided by different sources. According to one source, Cameroon has a total population of 24 million inhabitants with a population density of approximately 50.5 inhabitants per $\mathrm{km}^{2} .{ }^{29}$ According to another source, the population is unevenly distributed over a surface area of $475,442 \mathrm{~km}^{2}$, giving an average population density of 40.8 inhabitants per $\mathrm{km}^{2} .{ }^{30}$ This is, of course, not a depiction of the true distribution of the population in Cameroon, because some areas are densely populated, some are moderately populated, and some are sparsely populated, while other areas are uninhabited. The areas of high population density in Cameroon include the Western Highlands, part of the Coastal Lowland around Douala and the extensive plantation zone along the coast, the Mandara Mountain region in the north, and the western part of the Southern Low Plateau around Yaoundé. The average population density in these

25 See Banco Santander, S.A website, at https://en.portal.santandertrade.com/establish-overseas/cameroon/investing, accessed 23 May 2019.

26 Ibid.

27 See IndexMundi website, at https://www.indexmundi.com/Cameroon/economy_profile.html, accessed 28 January 2021.

28 See Banco Santander, S.A website, at https://bit.ly/3vOIXoW, accessed 23 May 2019.

29 National population census data, 2005.

$30 \operatorname{BUCREP}(2010: 19)$. 
areas ranges between 100 and 200 inhabitants per $\mathrm{km}^{2} .{ }^{31}$ The highest population concentrations are registered in the main urban centres of Douala, Bafoussam, Foumban, Bamenda, Limbe, Yaoundé and Mokolo in the Mandara Mountain region. The main factors responsible for the high population densities are the fertile volcanic soil in the Coastal Lowland and the Western Highlands, the gentle topography in the Coastal Lowland, the concentration of industries in the Coastal Lowland, and dense transport network. The level of education in Cameroon is more than average. ${ }^{32}$ In 2015, the adult literacy rate was $75 \% .{ }^{33}$ This adult literacy rate increased from $41.2 \%$ in 1976 to $75 \%$ in 2015, growing at an average annual rate of $18.84 \%{ }^{34}$ The current educational level of Cameroon is contained in the Strategy Paper of the Education and Training Sector, $2013-2020^{35}$ - the education plan of Cameroon, whose primary objective is the achievement of quality universal primary education. This objective aligns with the national strategy for growth and employment goal of providing the production system with human capital capable of supporting economic growth. From 2006, the enrolment growth has been strong at all levels except at the primary level where it has been more modest: Pre-school $+56 \%$; Primary $+14 \%$; Secondary General $+58 \%$; Technical Secondary $+75 \%$; and Superior $+85 \%$. $^{36}$

There is freedom of religion in Cameroon. The Preamble of the Constitution of Cameroon proclaims the freedom of religion, and the government respects this right by allowing for free practice of religion. Thus, the country is generally characterised by a high degree of religious tolerance. However, for a religious group (apart from African traditional religions) to be legally functional, it has to be registered as per Law No. 90/053 of 19 December 1990 on Freedom of Association. There are three predominant religions in Cameroon consisting of Christianity, Islam and traditionalist. Christian churches and Muslim centres of various denominations operate freely throughout the country, while the traditionalists operate in their shrines and temples. Although there is religious diversity and freedom in Cameroon, the most common religious belief is Christianity, which is adhered to by approximately two-thirds of the country's population. ${ }^{37}$ Islam is the second most practised religion in Cameroon by roughly onefifth of the population. A few others practise African Folk Religion and other religions, while some claim to have no religious belief. ${ }^{38}$

The Roman Catholic Church is the most dominant Christian faith group in Cameroon constituting about $39.2 \%$ of the total population, followed by the Protestants with

31 Ibid.: 1.

32 See https://bit.ly/3s9dtau, accessed 19 July 2019.

33 Ibid.

34 Ibid.

35 Republic of Cameroon (2013).

36 Ibid.: 28.

37 See Spain Exchange country guide website, at https://www.studycountry.com/guide/CM-religion.htm, accessed 19 July 2019.

Ibid. 
about $28.1 \%$ of the population; Islam constitutes about $19.5 \%$ of the population; about $4.3 \%$ of the population, mainly in rural areas, still retain their indigenous religious practices referred to as African Folk Religion involving practices such as rituals in the form of animal sacrifices, and ancestor and spirit worship. ${ }^{39}$ Other religious groups in the country include atheists and agnostics, estimated at $4.6 \%$, and Hinduism estimated at $2.1 \%{ }^{40}$ All these religious groups have an impact on the cultural and national life. For instance, most religious holidays are declared as national holidays, while the religions dictate and influence cultural practices such as food, dress, and moral conduct. ${ }^{41}$ An important objective of various religious groups is the quest for land to spread their confessional beliefs. In this regard, the Catholics and Protestants have acquired large expanses of land across the country, both in the rural areas and urban areas.

\subsection{Information on the organisational structure of Cameroon}

Cameroon has three main powers of the state, namely the Bicameral Legislative, the Judiciary, and the Executive. Although it is said that Cameroon operates as a democratic system of government, it has had a strong centralised system of government dominated by the President since 1972. Cameroon, which was once a federal system, is now a decentralised unitary state as per Article 1(2) of the Constitution. It is made up of a central government and 10 regions. ${ }^{42}$

\subsubsection{Legal system and legal tradition}

Cameroon is a bilingual and bi-jurial country with two systems of law operating side by side. The legal system, like most in Africa, is a relic of the colonial era. ${ }^{43}$ However, it is unique in that it consists of two distinct and often conflicting legal systems, the English common law and the French civil law, operating in some sort of tenuous coexistence ${ }^{44}$ However, it would be correct to say that Cameroon operates a mixed legal system of English common law, French civil law, and customary law. It must be noted

39 See Worldatlas website, at https://www.worldatlas.com/articles/religious-beliefs-in-cameroon.html, accessed 28 January 2021.

40 Ibid.

41 Ibid.

42 See Article 1(2) of the Constitution instituted by Law No. 96/06 of 18 January 1996 to amend the Constitution of 2 June 1972, amended and supplemented by Law No. 2008/001 of 14 April 2008.

43 See Hauser Global Law School program website, at https://www.nyulawglobal.org/globalex/Cameroon1.html\#_The_Cameroonian_Legal, accessed 23 May 2019. Ibid. 
that the country is fully engaged in the harmonisation of laws from the two legal systems representing two major world cultures - English and French.

\subsubsection{Competence of legislation}

In Cameroon, the initiative of elaboration of legal acts belongs to the legislative power and the executive power. ${ }^{45}$ The Cameroonian Constitution distinguishes between parliamentary power to legislate in Article 26 and the governmental power to issue rules and regulations in implementation of Parliamentary legislation in Article 27. Article 26 is the principal provision in the Constitution that specifies the scope of the Cameroon Parliament's legislative competence. This article, in broad terms, identifies the areas that fall within the reserved legislative domain. The parliamentary power to legislate is complemented by governmental power to issue regulations in implementation of such legislation. This is so because legislative texts are incomplete without their enabling instruments issued by the executive branch of the government, detailing and completing the legislative texts. Express governmental intervention in the legislative domain under the Cameroonian Constitution is provided for on two different occasions. The first is provided for by Article 27, which states that "matters not reserved to the legislative power shall come under the jurisdiction of the authority empowered to issue rules and regulations." This has the effect of giving the government the right to enact "laws" by way of "rules and regulations" in all matters not reserved for Parliament under Article 26. The President of the Republic (Article 8 (5)), the Prime Minister (Article 12 (3), and a host of other government officials share this general power to issue rules and regulations. The second instance of governmental intervention is provided for in Article 28 of the Constitution. According to this provision, Parliament may, on matters falling within its reserved legislative domain, "empower the President of the Republic to legislate by way of ordinance for a limited period and for given purposes." To be valid, such ordinances must be tabled before the bureau of the National Assembly and the Senate for purposes of ratification within the time limit laid down by the enabling law.

The legislative power deliberates and adopts bills, and the President of the Republic promulgates them into law. Regarding regulatory acts, the executive power and its down-the-line organs have exclusive authority to legislate. 


\subsubsection{Competence of law enforcement}

The enforcement of legal acts is incumbent on the Executive and the Judiciary, which act through law enforcement officials usually referred to as judicial police or judicial authorities. The national police and the gendarmerie have primary responsibility for law enforcement with the aid of other judicial police officers, such as the bailiffs and the military.

Law enforcement in Cameroon is weak and difficult to navigate owing to endemic corruption and significant delays in court procedures. Bribery, nepotism, and corruption are rife in almost all sectors of the Cameroonian Government and economy but is particularly prevalent in the judiciary and finance services. ${ }^{46}$ There is ample evidence of weak governance systems and lack of independence in the Judiciary.

The Executive arm of government is in charge of executing or implementing the law at the various levels of administration, be it central or decentralised, with the help of the agents of law enforcement. This involves, from a centralised perspective, government departments and, from a decentralised angle, regional entities, local councils and traditional authorities. This is covered respectively by the Constitution, ${ }^{47}$ the law creating regions, ${ }^{48}$ the local council law ${ }^{49}$ and the chieftaincy law. ${ }^{50}$

\subsubsection{The Constitution, statutory and customary law: Role of traditional entities}

Although the Constitution does not expressly articulate on the role of traditional entities with regard to customary law, Article 1(2) stipulates that the Republic of Cameroon recognises and protects traditional values that conform with democratic principles, human rights and the law. Traditional values here can be interpreted to mean customary law which is guarded and enforced by traditional entities. The role of traditional entities is also recognised in laws relating to Judicial Organization Ordinances of 2011 and the law on Traditional Chieftaincies of 1977.

46 See Business Anti-Corruption Portal website, Cameroon corruption report, at https://www.business-anti-corruption.com/country-profiles/cameroon/, accessed 23 May 2019.

47 Article 57(2).

48 Law No. 2004/019 of 22 July 2004 fixing the rules applicable to regions.

49 Law No. 2004/018 of 22 July 2004 fixing the rules applicable to councils.

50 Decree No. 77/245 of 15 July 1977 to organize Chiefdoms. See Articles 19, 20(1) and (2) and 21 . 


\subsection{The state of the environment}

The environment is the basis for the survival of many Cameroonians because of the extractive activities it provides for them. These activities are dominated by agriculture, grazing, timber and non-timber forest exploitation, mining, and fishing. Cameroon's diverse climatic conditions have fashioned an environment that is not uniform throughout the country. Generally, the state of environmental degradation in Cameroon remains relatively low though with significant variations in different parts of the country. Large-scale environmental degradation is most common in the northern Sahel zone and the Western Highlands of the country, owing to constant use of the land with inadequate or no fallow periods. ${ }^{51}$

\subsection{Different types of soil and their vulnerability in terms of degradation}

The soil types in Cameroon vary from place to place because of topography, amount of rainfall and natural occurrences. According to Ndzeidze, soils in Cameroon are classified into zonal and azonal soils found in different parts of the country. ${ }^{52}$ The zonal soils are made principally of ferralitic and ferruginous soils, while the azonal soils comprise alluvial and volcanic soils. There is also intrazonal soil. ${ }^{53}$

Zonal soils are formed under the influence of climate. The two main zonal soils found in Cameroon include ferralitic soil and ferruginous soil, collectively called Latosols. ${ }^{54}$

The ferralitic soil is a reddish or brownish soil found in the Equatorial Rainforest in the southern region of Cameroon between latitude $0^{\circ}$ to $5^{\circ}$ north of the equator. Its formation is influenced by the climate of the Equatorial Rainforest region characterised by heavy rainfall and high temperatures. ${ }^{55}$ There is intense chemical weathering in the region due to heavy rainfall and high temperatures. This results in the formation of deep soil profiles. Owing to heavy rainfall, soluble minerals like calcium and sodium are leached, leaving behind insoluble oxides of iron and aluminium near the surface to form the reddish or brownish soil found in the A-horizon. The B-horizon is made up of silica and base deposited in this layer. This gives the B-horizon a yellowish colour. The C-horizon is made up of small particles of clay regolith as a result of deep chemical weathering. ${ }^{56}$

\footnotetext{
51 Fogwe et al. (2001: 9).

52 Ndzeidze (2008: 6-7, 146).

53 Dobgima (2008: 323); Neba (1987: 74).

54 Dobgima (2008: 120-123, 323).

55 Nchangvi (2010: 46-47, 199).

56 Dobgima (2008: 134-136, 323).
} 
The ferralitic soil is also characterised by low nutrient content due to rapid decomposition. Litter supply is high in the region owing to the presence of a large biomass. The climate of the region, which is warm and humid with heavy rainfall and high temperatures, favours the presence of microorganisms and a high rate of decomposition. As such, the thick litter supply is easily decomposed to form humus, but the humus is quickly washed away by the heavy rainfall in the region through leaching and erosion. ${ }^{57}$ The ferralitic soil is not very good for farming, because the moment the land is cleared and exposed to rainfall, the soil minerals are easily washed away. However, the laterite which is a characteristic of this soil makes it good for road construction.

This is a hard and dry soil found mainly in the Adamawa Plateau and the Northern Lowlands where rainfall is low and temperatures are high. With the low rainfall and high temperatures, the movement of soil minerals is more upward. The soil minerals on top are baked by the sun to form a hard layer called hardpan. The ferruginous soil is reddish-brown in colour and has low organic matter and is skeletal in nature. The soil has low nutrients as a result of leaching, which does not support forest vegetation and is used mainly for the cultivation of grain crops such as groundnut, maize and millet. $^{58}$

In Cameroon, azonal soils are young soils without distinct horizons or layers; dark in colour and rich in minerals and are two main types: volcanic soil and alluvial soil. ${ }^{59}$ This type of soil is formed as a result of the breakdown of volcanic lava. In Cameroon, volcanic soil can be found around the foot of Mount Cameroon, especially around Buea, Muyuka and Idenau; and in the Western Highlands around Oku, Ijim Mountain region and Foumbot. ${ }^{60}$ Volcanic soils are very fertile and are good for farming, which is why there are many large farms and plantations around Mount Cameroon, where both food and cash crops are widely cultivated. The main food crops grown in the area are coco yam, yam, cassava, plantain and maize, while the main cash crops grown in the area are cocoa, oil palm, banana, rubber and tea. In addition, potato and vegetables such as carrot, cabbage and tomato are widely cultivated in the volcanic soils of the Western Highlands. ${ }^{61}$

This type of soil is made up of fine and loose materials broken down and deposited by rivers usually on lowland areas. Alluvial soil is a young soil without distinct horizons. In Cameroon, alluvial soils occur in the Coastal Lowlands and around flood plains. In the Coastal Lowlands, alluvial soil can be found in the Tiko-Douala plain, the Mungo region and the Douala-Kribi plain. Alluvial soils also occur in the flood plains of the Logone valley and Benue plain in the north, the Ndop plain, and Noun valley in the Western Highlands. Alluvial soils are very fertile and good for farming.

61 See generally Neba (1987: 33-37, 74); Dobgima (2008: 140); and Ndzeidze (2008: 12-24). 
There are many large farms and plantations in the Coastal Lowlands. Rice farming is carried out in the Logone valley, Ndop plain and Noun valley because of the fertile alluvial soil. ${ }^{62}$

Intrazonal soils are developed under the influence of local conditions. The main type of intrazonal soil found in some areas in Cameroon is hydromorphic soil which occurs in waterlogged areas of the coastal swamps along the coast of the Atlantic Ocean, the wetlands around the country, and the Mbo plain. ${ }^{63}$

\subsection{Main drivers of soil degradation}

Cameroon has soil types of varying qualities. While some of these soils are naturally of poor quality, the degradation of some of the soils is attributed to anthropogenic drivers. Contextually, soil degradation is a change in the soil health status resulting in a diminished capacity of the ecosystem to provide goods and services for its beneficiaries. Degraded soils have a health status such that they do not provide the normal goods and services of the particular soil in its ecosystem. ${ }^{64}$ Soil degradation in Cameroon is linked to a combination of drivers discussed in the subsections that follow.

\subsubsection{Agriculture}

The economy of Cameroon is largely agrarian, employing over $80 \%$ of the country's population. Agriculture in the country is dominated by subsistence small-scale farming practices, which are unsustainable and are at the forefront of causing massive soil degradation. ${ }^{65}$ Some of the common practices include slash-and-burn (also called swidden); bush burning; and the ankara system, especially in the Western Highlands of Cameroon. The practice of slash-and-burn, or rotational farming, underpins food production and livelihoods in Cameroon and many other countries. Slash-and-burn farming includes several phases: (i) clearing of a portion of forest; (ii) burning of the plant debris; (iii) cultivation of the land, generally for a brief period; and (iv) leaving the land to fallow, generally for a long period of time. So, it is not a form of permanent farming. When returns from land diminish, farmers shift cultivation to another plot and allow the previous parcel to lie fallow for some years to regain fertility. About $80 \%$ of rural populations in Cameroon practice rotation. Slash-and-burn agricultural practice is detrimental for soils. This type of agriculture affects vegetation and soil

62 See generally Nchangvi (2010: 62-66, 199); Neba (1987: 30-38); Dobgima (2008: 145-148); and Ndzeidze (2008: 26-29, 146).

63 See Neba (1987: 28-29); Dobgima (2008: 146-148, 323).

64 FAO (2015: 71).

65 FAO (2009: 192). 
carbon stocks. Increasingly, agriculture, especially accompanied by burning, has been contributing to soil degradation and climate change, as clearing - which is being intensified to meet the food demand of the growing population - exerts pressure on vegetation and soil, leading to loss of carbon stored in vegetation and soil in the form of carbon dioxide $\left(\mathrm{CO}_{2}\right){ }^{66}$

On the other hand, ankara is a traditional farming method practised by farmers in the Western Highlands of Cameroon with the aim of improving soil fertility and increasing crop production. Here, dry plant waste is put in the middle of beds, then partly covered with soil and then burnt. Then, seeds are planted on the burnt portions. During burning, much smoke is emitted, which indicates emission of carbon into the atmosphere with all that this entails for climate change and also reduction of soil fertility in the long run. ${ }^{67}$ In these highlands of Cameroon, agriculture is characterised by extensification and a reduction, and in some cases elimination, of fallow periods, giving rise to continuous use of the soil without significant improvements. The rugged nature of these highlands also exposes the soils to the high-intensity rain drops which easily loosen the particles, giving rise to extensive soil erosion of all types (gully, sheet and rill). Extensive grazing in the region is also a major contributor to soil degradation. Livestock grazing in the region is done using the free-range technique over communally owned lands ${ }^{68}$ This technique of grazing, along with non-respect for carrying capacity, has given rise to overgrazing, soil compaction and soil degradation. This accounts for the persistent reduction in the quality of pastures over the years.

In the South Low Plateau, there is the common occurrence of bush fallowing and shifting of cultivation, especially in the East region of the country, characterised by vast expanses of abundant land and a relatively sparse population density. The northern part of the country, characterised by extensive lowlands, is dominated by mono-cropping such as onion, sorghum, millet and other cereal crops. Most often, owing to the growing demand for land as a result of the continuous growth in the human population, the cultivation does not give adequate time for the soil to reconstitute its natural fertility. Equally, the intense traditional grazing methods, such as transhumance and pastoral nomadism, have led to overgrazing and intense trampling that have exposed the soils to agents of erosion, especially wind erosion. The traditional farming methods and intense cattle-grazing have also exposed the soil to the direct rays of the sun. The Coastal Lowlands are characterised by large-scale plantations, such as the Cameroon Development Cooperation (CDC), Delmonté, PAMOL, Herakle Farms, and SOCAPALM. They use intense chemical fertilizers and pesticides that are not only harmful to the soil, but equally have detrimental effects on the underground water aquifers and the environment as a whole. The peasant subsistence small-scale farming

67 See Njoh et al. (2018: 24).

68 Fogwe et al. (2001: 10). 
practices carried out in this zone suffer considerably as a result of declining soil fertility and a drop in agricultural output. The small-scale farmers in this zone depend largely on the natural resource base for improving livelihood conditions. They have also resorted to extension of farming plots as a means of increasing farm output to meet the food needs of the population. The growing population and demand for food have significantly reduced or completely eradicated fallow periods, giving rise to overuse of soils and resultant degradation.

\subsubsection{Mining}

Given that Cameroon is richly endowed with mineral deposits, large-scale mining is being carried out in the country. Indeed, huge mining potential exists, as exploration studies have shown that the country is rich in sub-surface precious minerals. ${ }^{69}$ The major mining sites in the country include iron ore mining in Mballam and Betare-Oya, which are in the East Region, bauxite at Fongo-Tongo in the West Region around Dschang, and limestone mining around Fugil Hill in the north of Cameroon. ${ }^{70}$ Mining has an adverse effect on soil quality in that, during and after mining, toxic chemicals and acidic water are released, contaminating the environment, especially the soil. This changes the chemical composition of the soil and, since the chemicals are poisonous, they make the soil unsuitable for plants to grow. Furthermore, mining disturbance alters the flow of nitrogen through a stable soil-plant-microbial ecosystem. Furthermore, mining activities can result in erosion, sinkholes and the contamination of soils by the chemicals emitted from mining processes. The exploitation of these mineral deposits has generated much solid and liquid waste which has polluted vast expanses of the land. The mining companies in Cameroon exploit the mineral resources with impunity and do not take the protection of the environment into consideration. The environmental feedback in these areas has been reported to be negative with serious implications for soil degradation since the wastes generated are not treated before disposal. The current railway under construction, from Betare-Oya in the East region of Cameroon to the Kribi deep seaport, to ease the evacuation of mining products, has led to large expanses of forestland being cut down and has exposed the soils to agents of degradation in this part of the country. 


\subsubsection{Wildfires, farming, hunting, and cattle rearing}

Human-induced wildfires are another significant driver of soil degradation in Cameroon. Uncontrolled wildfires cause massive forest destruction, destroy topsoils and expose land to all forms of erosion, such as wind and rain erosion. Communities use fire for clearing for subsistence farming and hunting. Pastoral lands cover a considerable part of the national territory, but reliable figures on pasture expansion into forested areas are not available. Climate modelling predicts that the extent and severity of wildfires will increase under most climate change scenarios. ${ }^{71}$ Cameroon is a leading livestock-farming country with 6 million cattle and 7 million small ruminants on pastoral land covering more than $30 \%$ of the national territory and constituting more than 14 million hectares. ${ }^{72}$ Livestock farmers keep large livestock, triggering further burning to open up more land, especially in the mountainous forest regions, in order to allow regeneration of vegetation for their livestock, with direct implications for soil degradation.

\subsubsection{Industrial sites}

Generally, Cameroon is characterised by a very low level of industrialisation. As such, most of the raw materials extracted from the country undergo very little processing within the country. The main industrial sites in Cameroon are the coastal industrial region, with the Douala zone being the largest industrial concentration. There is also the central industrial region that cuts from Yaounde to Mbandjock and the BelaboMbalmayo zone. There is also the Western Highlands industrial zone, such as the Bamenda industrial zone that is yet to be developed; and the northern industrial region, where SODECOTON, a cotton-processing factory, and the cement factory that uses limestone at Fugil Hill are situated. Environmental management by a significant proportion of these manufacturing industries in Cameroon remains an issue that has been shrouded in politics with much lip service while actual implementation has remained a fallacy. Equally, the Chad-Cameroon multi-billion oil pipeline project has had some oil spillage. All these instances contribute significantly to degrading the soils and reducing their quality.

It is important to bring to the fore that a significant proportion of industries in Cameroon are not certified with international environmental management organisations, such as the International Standardized Organization (ISO 14001) series, which requires industries to internalise their externalities on the environment. ISO 14001 is a series of environmental management standards developed and published by the 
International Organization for Standardization (ISO) for organisations. The ISO 14001 standards provide a guideline or framework for organisations that need to systematise and improve their environmental management efforts. Simply put, ISO 14001 is an environmental management system (EMS) which ensures "a transparent, systematic process known corporate-wide, with the purpose of prescribing and implementing environmental goals, policies, and responsibilities, as well as regular auditing of its elements".

At present, there seems to be no evidence to show that companies in Cameroon are ISO 14001 certified. However, by 2015, the Cameroon sugar manufacturing company, SOSUCAM, was supposed to have been certified to ISO 14000. Most of these industries therefore generate a lot of air pollutants that cause acid rains that degrade the soils. Similarly, some of the solid and liquid wastes (chemical effluents) are not treated because of lack of certification to ISO 14000 and therefore no management policies to treat wastes or recycle. This greatly degrades the soils, water and the environment where these industries are concentrated..$^{73}$ Another soil degradation problem associated with industrialisation in Cameroon relates to oil and gas exploitation, especially refinery activities in the national refining company, SONARA, in Limbe, where the byproduct of refined oil, namely sludge, is dumped directly onto the land and into the ocean which contributes to marine and land pollution. ${ }^{74}$

\subsubsection{Urban sprawls}

Cameroon is a developing country that is experiencing a rapid increase in the population, bringing about urbanisation in the rural areas. The rural areas in Cameroon are rapidly urbanising with significant effects on vegetation cover. This has led to significant transformation of forestland into habitable spaces, as well as space for agriculture to meet the demand food production for urban and rural populations. The expansion of settlements and rapid deforestation are exposing the soil to various forms of erosion. This is visible from the large-scale extensification of subsistence farmlands around the peri-urban areas and the simultaneous use of poor farming methods and chemical fertilizers to grow crops rapidly. These practices have been noted for contaminating soils and reducing its productivity.

Furthermore, urban sprawl, due to the human population explosion and unsustainable socioeconomic development, has led to the degradation of wetlands. This has triggered a decline in the goods and services provided by these ecosystems. In fact, most wetland ecosystems are experiencing accelerated degradation in Cameroon. Reclamation and conversion of wetlands for agriculture, human settlement and industrial 
development constitute a considerable threat to the conservation of wetlands. ${ }^{75}$ Large areas of wetlands in Cameroon are being converted to agriculture, grazing, land reclamation or encroachment for development activities and housing, firewood and other construction materials. In recent times in most local communities, the majority of wetlands are being carved out and appropriated by community members because of the increasing value attached to land, generally, and to wetlands, in particular. In fact, pressure on wetlands continues to mount both in rural and urban areas, leading to largescale drainage and conversion for alternative uses without regard to their ecological and environmental values. As a result, a great number of wetlands in Cameroon are continually being degraded. They face severe and diverse threats with implications for soil degradation.

All these developments have taken place in the absence of an appropriate and comprehensive national legal framework that regulates the management, conservation and wise use ${ }^{76}$ of wetlands. This is compounded by the limited understanding of the population of their values and what the impacts of their modification and degradation may be. In fact, most wetlands are under threat owing to unsustainable use - which will continue in the absence of a suitable legal framework. Based on current trends, Cameroon is not doing well in responding to degradation of wetlands. Their management, conservation and wise use therefore deserve proper policy and legal attention. With regard to soil protection, wetlands provide supporting services such as nutrient cycling and soil formation, drought and flood control, soil erosion prevention, nutrient and toxic retention, prevention of saline water intrusion, etc. However, urban and rural encroachment on wetlands is affecting the role these ecosystems play in term of soil protection. Protecting wetlands from degradation can therefore enhance the protection of soils.

\subsubsection{Demographic growth rate}

Population growth and demographic explosion are a reality in Cameroon with the rural areas experiencing faster growth rates than urban areas. It should be recalled that the impact of the population policies that were initiated in the 1960-1980 period in order to expand the population have continued to date. In the aftermath of independence, Cameroon in its desire to consolidate its newly acquired sovereignty, took pride in having a large population, not only for reasons of national grandeur, but also and above all for the needs of economic development. Population growth was therefore

75 Kang (2013: 3); see also Kwame (2006: 10).

76 In Ramsar terms, wise use means the sustainable utilisation of wetlands for the benefit of mankind in a way compatible with the maintenance of the natural properties of the ecosystem. Thus, wise use of wetlands is the maintenance of the ecological character, achieved through the implementation of ecosystem approaches, within the context of sustainable development. 
encouraged, as there was insufficient market for products. Indeed, the general policy report of the Head of State on 25 September 1960 says: "Among the limitations to the incentive to invest, we must mention economic factors such as the low density of the local market, below the break-even point ...." ${ }^{77}$ The alarming growth in the size of the population today was long desired. Indeed, before 1980, the population as a factor of development and as a political asset was highly valued in terms of its contribution to socioeconomic development of the country and to slowing down the aging of the population. ${ }^{78}$ It would seem, therefore, that, according to the governmental authorities, the limited population size did not allow two objectives to be adequately met: firstly, to have an economic market sufficient to carry out profitable investments, and secondly, to take the country out of underdevelopment. The moderate figure of the population also did not allow the leaders of Cameroon to satisfy their desire for national greatness, as testified by President Ahmadou Ahidjo in his speech of 21 December 1964: ${ }^{79}$

Me too, I can dream that my country is as big as the United States of America and as big as Russia, but when I wake up, I see that my country is Cameroon with its four million inhabitants.

This explains why births and population expansion were encouraged. The increasing demographic growth experience, especially in the rural areas where agriculture is the main source of rural livelihood, has led to extensification as well as unsustainable grazing practices to satisfy the food needs of the growing population. The effects have been that vast expanses of forests and wetlands have been cut down for the growth of crops and for housing construction. The exposed environment, void of trees especially on hilly terrain, is thus characterised by intense mass movement processes such as landslides and soil erosion. Population growth is therefore associated with increased environmental degradation and declining productivity of soils. The Cameroonian Government's new position on demographic issues was made official at the World Population Conference in Mexico in August 1984, in the following words: ${ }^{80}$

Aware of the impact of the increase in population ..., we do not encourage the proliferation of large and needy families. We think of directing our population policy towards the improvement of the quality of the population (...).

2.3.7 Weather and climate factors: The symbiotic relationship between soil and climate change

Weather and climate are related. and they differ in some respects. The distinction between weather and climate lies in the fact that weather is the climatic conditions or patterns seen over a short period of time in a given location, while climate is the

78 Ibid.: 20.

79 Ibid.

80 Ibid.: 24. 
average weather patterns seen over decades. Climate change is caused by the emissions and concentration of greenhouse gases (GHGs), mainly carbon dioxide $\left(\mathrm{CO}_{2}\right)$ and methane $\left(\mathrm{CH}_{4}\right)$, in the atmosphere. There is a symbiotic relationship between climate change and soil. To better understand the symbiosis, it is appropriate to ask the following questions: What is the impact of climate change on soil? Can soil help combat climate change?

Climate change can affect soil functions directly and indirectly. The direct effects include soil process changes in organic carbon transformations and nutrient cycling through altered moisture in the soil or increased soil erosion rates due to an increased frequency of high-intensity rainfall events ${ }^{81}$ Varying climatic conditions in Cameroon have influenced soil degradation in various ways. In the northern Sudano-Sahelian zone where average temperatures are above $28^{\circ} \mathrm{C}$ and there is a longer drier season, the common occurrence of droughts has caused soil moisture deficit and a high rate of evapotranspiration, affecting the quality of the soils in this zone. The active hamattan winds in this zone contribute equally significantly to the rapid removal of the topsoil. The equatorial climatic zone of the south, where rainfall is high throughout the year, has increased constant leaching of silica, allowing ions and aluminium compounds to accumulate on the topsoil. This increases the acidic contents of the soils and reduces its productive value. In the Western Highlands, the high rainfall intensities where soils are exposed loosen the soil particles, giving rise to erosion and river siltation (as a result of huge quantities of topsoil being washed into rivers every year). The indirect effects of climate change on soil functions include those that are induced by climate change adaptation options. ${ }^{82}$ Since soils are intricately linked to the atmospheric-climate system through the carbon, nitrogen and hydrological cycles, altered climate will have an effect on soil processes and properties and, at the same time, the soils themselves will have an effect on climate. ${ }^{83}$ Global climate change is projected to have various important effects on soil processes and properties related to restoring soil fertility and productivity. ${ }^{84}$

On the other hand, soil is one of the carbon sinks and reservoirs whose protection and conservation is critical for climate change mitigation. Substantially more carbon is stored in the world's soils. It is estimated that the global soil carbon pool of onemetre deep, estimated at 2,500 $\mathrm{PgC}$, of which about 1,500 $\mathrm{PgC}$ is soil organic carbon, is about 3.2 times the size of the atmospheric pool and 4 times that of the biotic pool. ${ }^{85}$ The role of soil organic carbon in global carbon cycles is receiving increasing attention both as a potentially large source of carbon dioxide emissions and as a natural carbon

81 Hamidov et al. (2018).

82 Ibid.

83 Brevik (2012: 1).

84 Pareek (2017: 136).

85 Zomer et al. (2017: 1). 
sink capable of reducing the concentration of atmospheric GHGs. ${ }^{86}$ It is possible to influence atmospheric levels of carbon- and nitrogen-based gases through soil management. ${ }^{87}$ Thus, one of the means to limit temperature increase and fight climate change is avoiding soil degradation. Maintaining soil carbon is a natural and cost-effective way of mitigating climate change.

Where we have the ability to sequester and conserve carbon in the soil, management decisions can lead to the release of carbon from the soil, making it a net source of GHGs. ${ }^{88}$ Ploughing native soils for agricultural production, introducing more aggressive forms of tillage, and draining wetlands are examples of management practices that increase GHG emissions from soils. ${ }^{89}$ The danger of intensively cultivated areas in Africa has been emphasised..$^{90}$

\subsubsection{Topographic constraints}

The topography of Cameroon is highly diverse. Topographically, the country is made up of the Coastal Lowlands, the South Cameroon Low Plateau, the Western Highlands, the Adamawa Plateau and the Northern Lowlands. This diverse topographical configuration has given rise to changes in the quality and quantity of soils. In most of the highland areas, the soils are generally eroded. The physiographic configuration of the Western Highlands, characterised by volcanic mountain ranges with very steep slopes, has exposed the soils to natural hazards such as landslides, soil creep and rockfalls, which all reduce soil quality and quantity. ${ }^{91}$ Geomorphic agents such as water and wind are also very active in these areas which carry away the topsoils. On the contrary, the low-lying areas of Cameroon such as the Northern Lowlands and the Coastal Plains, as well as broad topographic depressions such as the Ndop, Mbaw and Santchou Plains, are endowed with fertile alluvial soils which are consistently washed away from the adjacent highlands into these plains by streams and rivers.

\subsubsection{Land-grabbing}

Land-grabbing is arguably defined as the large-scale land acquisitions or the buying or leasing of large expanses of land mostly in developing countries by domestic and

86 Ibid.

87 Brevik (2012: 2).

88 Ibid.: 4.

89 Ibid.

90 Zomer et al. (2017: 1).

91 Lambi (2000: 139). 
transnational companies, organisations, and individuals. ${ }^{92}$ Land-grabbing is also associated with soil degradation. Soil degradation can be incentivised by the grabbing, appropriation and use of lands by large agro-investors in collusion with the government. Although in most rural areas, most lands are still held under customary tenure systems and administered by traditional rulers, customary tenure no longer provides people with security over their land as vast lands are forcefully acquired by the government and its allies - powerful agro-industrial corporations, influential elites, and some traditional leaders. The large influx of investors in Cameroon and the acquisition of thousands of hectares of land for the establishment of plantations will put more pressure on soils through clearing, the use of toxic and hazardous chemicals and poor waste management. The increased value that these large expanses of land used mainly for agriculture and other economic activities have placed on land constitutes a potential driver of soil degradation.

\subsubsection{Other causes or drivers of soil degradation}

Soil degradation in Cameroon is also driven by a series of underlying drivers including deforestation, pollution, compaction, salinisation, soil erosion, the loss of soil organic matter and migration.

Deforestation is a threat to soils and exposes these to high temperatures which break down the organic matter, increase evaporation, and make soils vulnerable to erosion. Furthermore, soils around the coastal industrial zones have been contaminated by industrial pollutants involving effluents from industries. In the agro-industrial complexes, the use of chemicals and pesticides has equally given rise to soil degradation and environmental traumatisation in general. This is especially in the agro-industrial establishments in the Coastal Lowlands of the country, where fertilizers and agrochemicals are used in high-input agriculture, in mining, and for oil spills. The high rate of chemical and pesticide use in agro-industrial establishments has resulted in an increase in the acidic content of soils with enormous impact on the health of the soils. In their study on the biochemical indicators of marine pollution in the Douala Lagoon and Limbe Estuary in Cameroon, Etame and Oben ${ }^{93}$ posited that there is a great variety of pollutants produced by human activity, many of which reach the aquatic environment. These pollutants emanate from industrial, agro-industrial, to municipal sources, and others come from mining, silt, oil spillages and leakages, and oil from garages.

Soil compaction in Cameroon is common in the northern Sahel region where the activities of the Fulani cattle herders have caused large sections of the soils to become barren landscape through trampling. This is coupled with the prolonged drought 
conditions that are common characteristics in this zone. The higher temperatures of this zone have caused the soils to become scorched, so that they can hardly support the growth of some crops.

The low-lying nature of the Cameroon Coastal Lowlands between Douala and Tiko estuaries ensures that inundation remains a constant threat and is expected to get worse with accelerated rise of sea levels. A direct consequence is the continued loss of wetlands dominated in the Cameroon Coastal Lowlands by the mangrove forest vegetation. Salinisation of soils and groundwater is already a huge problem in the DoualaEdea-Kribi area to the east and the Douala-Tiko area to the west of the depositional sedimentary basin of the Cameroon Coastal Lowlands. The Cameroon Coastal Lowlands are floodtide dominated by mangroves that proliferate in the shoaling lagoons, creeks and tidal inlets. There is increasing intrusion of salt water into the shallow aquifers of this coastal area. The visible consequences include hazards such as saline soils and flooding. This is thus a fragile and unstable zone.

Soil erosion is the rapid loss of soil as a result of both natural causes and unprecedented human activities that exceed the rate of soil formation. Soil erosion caused by wind or water leads to the loss of surface soil layers which are rich in organic and mineral nutrient pools, resulting in complete or partial loss of soil horizons and possible exposure of growth-limiting subsoil. ${ }^{94}$ The process of soil erosion is accelerated by human activities, resulting in reduced soil stability and leading to soil creep and landslides. ${ }^{95}$ Erosion remains one of the principal threats to the soils in Cameroon. The hilly physiographic landscape of Cameroon, especially in the Western Highlands of the country dominated by savannah vegetation, has over the years been exposed to frequent soil erosion during the rainy season where fluvial activities are at their peak. These fluvial processes on the hilly landscapes have accelerated the rate of soil loss through erosion. Apart from the natural processes, anthropogenic activities have equally accelerated the process of soil erosion. The high population density in this part of the country, coupled with the fact that the population relies on natural resources for a livelihood, has led to vast expanses of the vegetation being cleared for agriculture and settlement. Similarly, the various land tenure practices and the decrease in the fallow periods have resulted in a situation where the land is exploited continuously without adequate time for soil restoration. This has accelerated the rate of soil loss through erosion and landslides. ${ }^{96}$

The loss of soil organic matter is common in Cameroon and has for a long time lowered the ability of the soil to maintain its production potential. There has been a loss of soil organic matter in some of the soils in Cameroon, especially in the Coastal Lowlands of the country that play host to large agro-industrial estates characterised by

95 Ibid.

96 Tassah (2019). 
the high use of chemical fertilizers and pesticides that most often kill the soil microbes. This has also been occurring in the Western Highlands of the country where land-use changes are common. Historically, land-use changes in the Western Highlands, where the highlands were reserved as ancestral sites for the gods during the 1960s, have been characterised by agriculture, grazing and settlement land uses. ${ }^{97}$ There has been a reduction in the use of manures and an increase in cultivation depth. These practices have resulted in the reduction of organic inputs and increased decomposition of existing soil organic matter. The topsoils are those most affected, as the topsoil is the main zone affected by land use.

Whether international or national, migration and land/soil degradation are closely interconnected processes, which are triggered by intervening social, economic, political, demographic, and environmental processes, occurring at scales from the local to the international. ${ }^{98}$ In developing regions, soil degradation is partly driven by those that are heavily dependent on basic ecosystem goods and services who often resort to migration to diversify their livelihood strategies and sources of income, or do so in response to the exigencies of socioeconomic and political unrest, and environmental conditions. ${ }^{99}$ With regard to fertility, migration mostly flows from areas of high degradation to those of less, with low yields often escalating migration flows. Tropical regions covered with forests and wetlands often attract migrants from other areas who seek to establish farmlands - this can further drive deforestation and land/soil degradation. Environmental changes, conditions and processes are negative precursors for migration, ${ }^{100}$ which is responsible for soil degradation.

In recent times, mass internal migration caused by social, economic and political factors in Cameroon is a threat to the soils. The case of internally displaced persons (IDPs) in Cameroon as a consequence of a sociopolitical crisis in the Northwest and Southwest, two English-speaking regions of the country, is escalating, with potential significant soil degradation impacts. There is a steady increase in the influx of IDPs from the two regions to other regions of the country, especially to the West, Littoral and Central Regions for resettlement purposes to satisfy their food and socioeconomic needs. The effect is the exposure of soils to serious degradation threats owing to increased encroachment and pressure on land (forests and wetlands), which are being cut down for housing construction and settlement and for agriculture involving the use of unsustainable practices. Migration is therefore associated with increased environmental and soil degradation.

Ibid.: 211.

98 McLeman (2017: 3); see also IOM \& UNCCD (2019: 1 and 6).

99 McLeman (2017).

100 Olimova \& Olimov (2012: 8). 
Soil degradation in Cameroon has been facilitated by several actors and therefore it becomes difficult to selectively hold a particular actor to be the main agent accountable for soil degradation. These actors range from foreign investors, to farmers and industrial operators.

The role of foreign investors as actors of soil degradation in Cameroon is deeply felt in the agricultural and mining sectors. The mining of huge mineral deposits in Cameroon have seen large quantities of earth materials excavated, leaving the mining sites bare of fertile land and rendering the landscape desolate. Therefore, foreign investors constitute some of the actors to be considered in the process of developing a model for land management in Cameroon.

Large- and small-scale farmers constitute the principal actors in soil degradation in Cameroon. The large-scale agro-industrial establishment in the Coastal Lowlands of Cameroon and the use of industrial chemicals and pesticides have had serious implications for the soil quality, while small-scale farmers who depend on the soil for basic livelihoods have been noted for degrading the soil as they employ unsustainable practices in the process of crop cultivation. This does not augur well for the health of the soil. The small-scale farmers remain the most implicated actors in soil degradation in Cameroon.

The activities of most of the industries in Cameroon have a deleterious effect on environmental protection and soil restoration. With the discharge of effluents and other waste, the health of the soils is not considered. This is basically due to weak enforcement of environmental laws, institutional lapses and corruption. The growing contamination of the soil and water in Cameroon is attributed to the poor urbanisation and industrialisation processes. ${ }^{101}$ Generally, these processes have preceded planning. In the case of Douala, which is the main industrial hub of the country, industries are located on an elevated terrain, while human populations are concentrated in lower-lying areas. As a result of poor planning, it has therefore been difficult to properly address the problems of liquid and solid waste pollution. ${ }^{102}$ Industries in Cameroon thus remain some of the actors of soil degradation.

\subsection{Conclusion}

It should be noted that not all drivers of soil degradation command equal importance, as the impacts of some drivers are greater than others. It would seem that the main drivers and causes are mining and industrial operations which lead to soil

101 Fogwe et al. (2001: 8).

102 Ibid. 
contamination; unsustainable agricultural practices by small-scale farmers; pesticide use by both small- and large-scale farmers; demographic growth rate or urbanisation, particularly on wetlands; weather and climate change; wildfires in the course of farming, hunting, and cattle rearing; topographic constraints; and land-grabbing. Apart from the main drivers, other causes or threats to soil degradation include deforestation; contamination by industrial chemicals and pesticides; soil compaction or soil sealing; salinisation; erosion; and loss of organic carbon and soil biodiversity. It should also be noted that foreign investors; small- and large-scale farmers; and industrial operators constitute the key actors in soil degradation in Cameroon.

As the basis of virtually all terrestrial life, without which human and many other forms of life on earth cannot exist, soil is both an inherent part of biodiversity and the major part of its foundation. ${ }^{103}$ The crucial ecological and socioeconomic functions of soil and the soil degradation challenges justify or warrant the need for the legal protection of soil. A sound legal and institutional framework for managing soils is critical. The legal framework relating to the protection and sustainable management of soils in Cameroon is not contained in a single legal instrument but is diverse and dispersed in numerous instruments having implications for soil protection. In this regard, the protection and sustainable management of soils in Cameroon is provided for in fundamental legislation as well as in different sectoral laws. At the national level, the legal architecture is organised in a hierarchical manner as follows: The Constitution; duly ratified treaties and international agreements; legislation or laws enacted by Parliament; ordinances of the President; Presidential Decrees; Prime Ministerial Decrees, Orders and Circulars; Ministerial Orders, Decisions and Circulars; Gubernatorial Orders and Circulars; Prefectorial Orders; and Municipal Orders.

Each category of such legal norms has addressed in its own way questions relating to the protection and management of soils. The same is true concerning the institutional framework for the protection and management of soils. In fact, a good number of public administrations have, within the framework of their missions, the protection and sustainable management of soils. However, the Ministry of Environment, Protection of Nature and Sustainable Development (MINEPDED) is the main public administration in charge of questions relating to the protection and sustainable management of soils. 
3.1 Policy frameworks, government strategies, action plans, etc.

Soil protection policy was elaborated upon by the Government of Cameroon within the perspective of protecting living beings and the environment in general and particularly zones with high potential for soil degradation. National policy frameworks, government strategies, action plans, etc., relevant to soil protection in Cameroon build on international policy instruments relevant to sustainable soil management. Thus, this section will consider both international and national policies relevant to soil protection in Cameroon.

\subsubsection{International policies relevant to soil protection}

\subsubsection{The land degradation neutrality initiative}

During its 12th Conference of the Parties (COP), the United Nations Convention to Combat Desertification (UNCCD) defined land degradation neutrality (LDN) as: ${ }^{104}$

a state whereby the amount and quality of land resources necessary to support ecosystem functions and services and enhance food security remain stable or increase within specified temporal and spatial scales and ecosystems.

The objective of LDN is to maintain and enhance the natural land and its associated ecosystem services. The UNCCD provides the international framework for the ongoing development and implementation of the LDN concept that partly seeks to protect the soil. ${ }^{105}$ In this regard, the Science-Policy Interface of the UNCCD led to the development of the so-called 'Scientific Conceptual Framework for Land Degradation Neutrality', which should provide a conceptualised scientific model approach for planning, implementing and monitoring the LDN initiative at national or regional level. ${ }^{106}$ Actions to achieve LDN include sustainable land management practices that prevent or mitigate degradation, and all efforts to reverse degradation through rehabilitation or restoration of degraded lands. According to Cowie et al., the response hierarchy of reverse land degradation articulates the priorities in planning LDN interventions. ${ }^{107}$ The implementation of LDN is done at the landscape level through integrated land-use planning. The pursuit of LDN requires effort to avoid further net loss of the land-based natural capital. ${ }^{108}$

104 Decision 3/COP.12, UNCCD, 2015.

105 See Cowie et al. (2017: 25).

106 Ibid.

107 Ibid.: 25.

108 See Orr et al. (2017: 3). 
3.1.1.2 The 2030 Agenda for Sustainable Development instituting the Sustainable Development Goals

Adopted by the United Nations General Assembly, the global 2030 Agenda for Sustainable Development contains 17 Sustainable Development Goals (SDGs) with 169 associated targets which are integrated and indivisible as commitments for both developing and developed countries. Among the 17 goals, the most relevant for soil protection is Goal 15. It sets out to protect, restore and promote sustainable use of terrestrial ecosystems, sustainably manage forests, combat desertification, and halt and reverse land degradation and halt biodiversity loss. More specifically, Target 15.3 urges states to strive to achieve a land degradation neutral world by 2030 , thereby constituting the most critical target for soil protection. Other related goals relevant for soil protection include Goal 12 which sets out to ensure sustainable consumption and production patterns; Goal 13 which encourages everyone to take urgent action to combat climate change and its impacts; and Goal 17 which sets out to strengthen the means of implementation and revitalise the Global Partnership for Sustainable Development. In line with Goal 13, soil is one of the carbon sinks and reservoirs whose protection and conservation is critical for climate change mitigation. Maintaining soil carbon is a natural and cost-effective way of limiting climate change. Thus, one of the means to limit temperature increase and fight climate change is avoiding soil degradation. The SDGs referred to above are therefore a panacea for achieving sustainable soil management.

\subsubsection{The African Union Vision 2063: The Africa We Want}

The African Union (AU) Vision 2063, commonly known as Agenda 2063: 'The Africa We Want', adopted in September 2015, is Africa's blueprint and master plan for transforming Africa into a global powerhouse of the future. ${ }^{109}$ It is the continent's strategic framework that aims to deliver on its goal for inclusive and sustainable development. It is a concrete manifestation of the pan-African drive for unity, self-determination, freedom, progress and collective prosperity pursued under Pan-Africanism and the African Renaissance. ${ }^{110}$ In fact, Agenda 2063 is the concrete manifestation of how the continent intends to achieve this vision within a 50-year period from 2013 to $2063 .{ }^{111}$ Among the seven Aspirations for 'The Africa We Want', the most relevant for soil protection is Aspiration 1 which sets out to achieve 'A prosperous Africa based on inclusive growth and sustainable development'. It however does not specifically mention soil. Paragraph 10 details that Africa will have the means and resources to drive

109 See African Union website, at https://au.int/en/agenda2063/overview, accessed 5 June 2019.

110 Ibid.

111 Ibid. 
its own development, with sustainable and long-term stewardship of its resources. Africa's unique natural endowments, its environment and ecosystems, including its wildlife and wild lands, will be healthy, valued and protected, with climate resilient economies and communities. According to Paragraph 72(b), the aspiration is to speed-up actions to ensure effective and territorial planning and land tenure, use and management systems. These are all relevant to soil protection.

\subsubsection{The Regional Implementation Plan for the African Soil Partnership}

Cameroon is a member of the Regional Implementation Plan for the African Soil Partnership (AfSP) adopted in 2016 that recognises the importance of land or soil as the main resource base for many people in sub-Saharan Africa. AfSP calls for the strong support of national governments, as well as national and regional entities involved in natural resource management to contribute to achieving the common goal of improved and sustainable soil management. The implementation of the AfSP in sub-Saharan Africa is structured on five main pillars which are all relevant to sustainable soil management.

Pillar 1 promotes sustainable management of soil resources for soil protection, conservation and sustainable production. Pillar 2 encourages investment, technical cooperation, policy, education, awareness and extension in soil. Pillar 3 promotes targeted soil research and development focusing on identified gaps, priorities, and synergies with related productive, environmental, and social development actions. Pillar 4 enhances the quantity and quality of soil data and information: data collection (generation), analysis, validation, reporting, monitoring and integration with other disciplines. Pillar 5 anchors on the harmonisation of methods, measurements and indicators for the sustainable management and protection of soil resources.

The implementation plan of AfSP also recognises several main areas of action as a priority in sub-Saharan Africa: Addressing soil degradation as a major factor in food insecurity and making country- and region-wide efforts to rehabilitate degraded lands and change them into productive assets through community participation (relates to Pillar 1); guiding and enabling the implementation of sound and sustainable soil management practices and the restoration of soil health at all levels to achieve food security (relates to Pillar 1); developing, updating and disseminating updated and harmonised national and regional soil resource information, addressing all user needs including soil fertility information and making the best use of available science to increase soil productivity (relates to Pillars 4 and 5); addressing climate change and developing resilience to climate change adaptation (relates to Pillars 1 and 3); developing and implementing training and capacity-building programmes in all soil applications for existing and new generations of experts in soil science and land management, taking into account the gender balance (relates to Pillar 2); and establishing linkages and networks 
with other national, regional and global initiatives that affect soil health (relates to Pillars 1 and 2).

\subsubsection{The Green Wall for the Sahara Initiative}

Furthermore, the Green Wall for the Sahara Initiative, a programme initiated by the African Union and developed by the African Union Commission in collaboration with the Food and Agricultural Organization (FAO), United Nations Environment Programme (UNEP), UNCCD, among others, was launched in December 2006. African heads of state and government in their summit in January 2007 adopted the Decision on the implementation of the initiative. The programme covers a wide group of countries, including Algeria, Tunisia, Libya, Egypt, Mauritania, Mali, Niger, Chad, Sudan, Eritrea, Ethiopia, Djibouti, Cameroon, Nigeria, Benin, Burkina Faso, Senegal, Gambia, and Western Sahara, and Cape Verde. The goals of the programme are to slow the advance of the Sahara Desert, enhance environmental sustainability, control land degradation, promote integrated natural resources management, conserve biological diversity, contribute to poverty reduction, and create jobs. ${ }^{112}$ The objectives of this initiative are relevant also to sustainable soil management.

\subsubsection{Other regional and sub-regional commitments of Cameroon relevant to} sustainable soil management

Cameroon subscribes to some sub-regional initiatives which are relevant to sustainable soil management notably within the Economic Community of Central African States (ECCAS), Central African Economic and Monetary Community (CEMAC) and the Congo Basin, all under the framework of the Central African Forests Commission (COMIFAC). ${ }^{113}$ In terms of sustainable management of soils, COMIFAC and the treaty ${ }^{114}$ establishing it commits state parties to undertake - within the scope of the conservation and sustainable management of forest ecosystems of Central Africa, among others - to include the conservation and sustainable management of forests and the management of the environment in national priorities; and to adopt measures aimed at putting forest conservation and sustainable management actions in line with

112 For information on the Green Wall for the Sahara Initiative Commission of the African Union, see https://www.unccd.int/actions/great-green-wall-initiative, accessed 31 January 2021.

113 COMIFAC is the Central African regional body in charge of forests and environmental policy, coordination and harmonisation, with the objective to promote the conservation and sustainable management of the Congo Basin's forest ecosystems.

114 Treaty on the Conservation and Sustainable Management of Forest Ecosystems in Central Africa, 2005. 
development programmes of other sectors, notably, agriculture. ${ }^{115}$ These have implications for soil protection.

Furthermore, in the framework of reforestation and management of ecosystems, COMIFAC adopted the Sub-regional Action Plan for Combating Land Degradation and Desertification, known by its French acronym PASR-LCD with implications for soil protection. In this respect, COMIFAC has a thematic working group on land degradation and desertification. Also, Cameroon like all other COMIFAC member states adheres to the Convergence Plan ${ }^{116}$ whose objectives are relevant for soil protection. In fact, the 2015 revised COMIFAC Convergence Plan contains relevant indicators for sustainable soil management. One of the six priority axes around which the 2015 revised Convergence Plan is structured is the conservation of biological diversity, which is relevant for soil. ${ }^{117}$ Another priority axis is combating the effect of climate change and desertification, which is equally relevant for soil protection. The Operation Plan of the Convergence Plan identifies its priorities for sustainable management of the Central African forests and is organised around the vision that COMIFAC members manage their forest resources in a sustainable and concerted manner for the welfare of their populations, and the conservation of biodiversity and the global environment. As part of the implementation of the COMIFAC Convergence Plan, Cameroon is involved in defining and implementing effective long-term strategies to combat land degradation in the sub-region. ${ }^{118}$

Through its subregional programme, the global mechanism established under the UNCCD is working with subregional institutions such as COMIFAC within the framework of ECCAS, to integrate the UNCCD into existing and emerging subregional development frameworks such as the COMIFAC Convergence Plan and to map the efforts to combat desertification, focusing on success stories in agriculture and natural resources management. ${ }^{119}$

Although some of these instruments do not specifically address soil, soil constitutes the most important element of land and natural resources, and reference to land, natural resources and ecosystems by these instruments provides an indirect means to protect soil. Furthermore, although these policies are not legally binding instruments, they can bring political pressure to bear on states to take appropriate domestic legal measures to achieve their objectives especially the reduction of soil degradation and ensuring its protection.

115 See generally Article 1 of the COMIFAC Treaty.

116 The Convergence Plan for the Conservation and Sustainable Management of Forest Ecosystems in Central Africa, February 2005, revised and adopted in July 2015.

117 Hannam \& Boer (2004: 1).

$118 \operatorname{GEF}(2007: 34)$.

119 UN Economic Commission for Africa (2007: 39). 


\subsubsection{National policies relevant to soil protection}

Policies, government strategies, action plans, etc., relevant to soil protection in Cameroon include:

\subsubsection{The National Environmental Management Plan}

The National Environmental Management Plan (NEMP) established in March 1996, forms part of the policy framework for environmental protection and its overall objective is to guide the development of strategies and actions for environmental protection and the rational management of resources to contribute to sustainable development. ${ }^{120}$ It is a general framework of reference for the various sectoral environmental management actions in Cameroon. Its five priority areas include participatory land-use management; sustainable management of natural resources; restoration of degraded land and improvement of soil fertility; capacity-building; and concerted management of shared resources at the subregional level. ${ }^{121}$ The NEMP has important implications for sustainable soil management and protection as it provides for the restoration of degraded land and improvement of soil fertility. The NEMP is only a policy instrument with no legal value because its implementation is not binding. Restoration is envisaged in response to natural or voluntary soil degradation. The restoration is done according to the type of degradation in question. If it is an excavation, for example, the degraded site can be transformed into a body of water. If it is deforestation, it can be restored through reforestation. When degradation results from natural causes, it is the responsibility of the state to ensure restoration, but if the degradation occurs after the completion of a project, it is the responsibility of the project promoter to ensure the restoration. It is necessary to distinguish whether it is an improvement of soils based on biological or organic elements (compost, for example) or chemical. Organic matter used to improve soil fertility does not greatly increase production, but it allows soil to retain its fertility. Improving the fertility of chemical-based soils increases soil yield, but these chemicals ultimately degrade the soils. The essence of restoration of degraded land and improvement of soil fertility is to reverse and reduce the environmental impacts caused by a project.

The NEMP has no standards to be achieved for restoration of degraded sites and this is probably a huge weakness because one can never ascertain if restoration has been effectively done in order to reduce soil degradation. It is perhaps important to

120 See the REDD Desk website at http://theredddesk.org/countries/plans/national-plan-environmental-management-cameroon, accessed 3 June 2018.

121 Ibid. 
mention that there is an urgent need to update the NEMP and one of the salient issues to rethink in that exercise will be setting standards for restoration of degraded lands.

\subsubsection{Intended nationally determined contributions of Cameroon}

In the lead up to the 2015 United Nations Framework Convention on Climate Change (UNFCCC) $)^{122}$ COP held in Paris in December 2015 during which the Paris Climate Change Agreement (PCCA) ${ }^{123}$ was adopted, parties were urged to submit their intended nationally determined contributions (INDCs) ${ }^{124}$ spelling out the actions they intended taking to address climate change - both in terms of adaptation and mitigation. Originally submitted as INDCs, these became binding nationally determined contributions (NDCs) when countries ratified the PCCA, unless they decided to submit new NDCs at the same time. The NDC became the first GHG targets under the UNFCCC for countries upon ratification of the PCCA. On 28 September 2015, Cameroon submitted its INDCs to the secretariat of the UNFCCC, in which it pledged a $32 \%$ reduction in carbon emissions by 2035 compared to its business-as-usual levels, taking 2010 as the reference year and conditional upon international support in the form of financing, capacity-building and transfer of technology. As a natural solution in fighting climate change, soils as natural carbon sinks enjoy a degree of protection in the NDC of Cameroon. Through its NDC, Cameroon intends to reduce the carbon footprint of its development without slowing its growth, identifying the soil as a critical component in meeting its carbon emission reduction pledge. Thus, the NDC provides for the promotion and adoption of better soil management practices in order to enhance soil productivity through, for instance, restoration. ${ }^{125}$

\subsubsection{The National Action Plan for the Fight Against Desertification}

The protection of living beings and the environment is partly done within the framework of the fight against desertification. In line with this, the National Action Plan for the Fight Against Desertification (NAP-FAD) was elaborated upon in 2007 by the government under the leadership of MINEPDED in collaboration with sister ministries, civil society, the private sector, and development partners. The action plan is

122 United Nations Framework Convention on Climate Change 11771 UNTS 107 (1992).

123 Adopted on 15 December 2015, signed in New York on 22 April 2016, entered into force on 4 November 2016.

124 INDCs is an expression used under the UNFCCC for reductions in greenhouse gas emissions that all countries that signed the UNFCCC were asked to publish in the lead up to the $2015 \mathrm{UN}$ Climate Change Conference held in Paris, France in December 2015.

125 See Republic of Cameroon (2015: 4, 5). 
considered as a government policy document within the framework of the fight against desertification, in general, and the protection of soils, in particular. In fact, upon ratifying the UNCCD in 1994, the government committed itself to working out a NAPFAD - a coherent framework for the control of desertification. ${ }^{126}$ The overall goal of the NAP-FAD is to reverse the desertification or degradation trends in order to fight against poverty and encourage sustainable development. ${ }^{127}$ The NAP-FAD identifies the Sudano-Sahelian zone of the country as the most affected zone in the desertification process. It is for this reason that the North and the Extreme North regions have been designated as zones for priority intervention. One of the major axes of the action plan is the restoration of degraded lands and the improvement of soil fertility. The objective of this axis is supposed to be achieved through the following results: the fertility of marginal soils is improved; degraded soils are restored; and techniques of soil restoration are mastered and used by the population.

In the present state of affairs, it is difficult to affirm that the foregoing results have been achieved. It is quite a vast project and the process is ongoing. The expected results are likely to be achieved over time. Furthermore, NAP-FAD identifies the level of degradation and the zones that are particularly sensitive to the phenomenon of desertification. This strategy provides a precise inventory of the causes and effects of the degradation of forestry landscapes, according to agro-ecological zones and some action corridors. NAP-FAD is aligned to the Decade Strategy (2008-2018) of the UNCCD and was elaborated upon to update the NAP-FAD of 2007.

Regarding efforts to implement the NAP-FAD in the two regions named above, the Ministry of Environment has, since 2008, executed the Operation Green-Sahel Project in the Extreme North region and the Project for the Development of Waterfalls in the Benoue in the North region of the country. There are a number of stakes to the degradation of soils. In the context of NAP-FAD, the process of desertification and degradation of soils appears complex and diversified. The problems and stakes associated with the phenomenon relate to reduction in the production of foodstuffs and livestock with the risk of famine, the scarcity phenomenon: exacerbated social cost. The manifestations of the phenomenon are more observable through degradation of soils; reduction in the surface area and productivity of useful agricultural soils; wood scarcity owing to reduction of forestry and natural resources training; sandy water plans and reduction in fisheries resources; disappearance of some animal and plant species and loss of biodiversity; and deterioration of living conditions and increasing precarious conditions of the poor rural populations. Considering demographic pressure and the resultant reduction in cultivable surface area, loss of soils in arid and semi-arid zones of Cameroon is estimated at about CFA F100 million, representing about one-third of the annual budget of the country. This must be taken seriously.

127 See Republic of Cameroon (2012: 43). 


\subsubsection{The National Biodiversity Strategy and Action Plan II}

As a policy tool, the National Biodiversity Strategy and Action Plan II (NBSAP II) provides an improved vision and a new orientation for interventions to reverse the trend of biodiversity loss. ${ }^{128}$ Given that soil is both an inherent part of biodiversity and the major part of its foundation, ${ }^{129}$ it can be concluded that the NBSAP II is relevant to soil protection.

\subsubsection{The Readiness Plan Idea Note and REDD+ Readiness Preparation Proposal of Cameroon}

The Readiness Plan Idea Note (R-PIN), 2008, and REDD+ Readiness Preparation Proposal (R-PP), 2013, of Cameroon were prepared in view of the national implementation of the REDD+ initiative. The REDD+ (reducing emissions from deforestation and forest degradation and the role of conservation, sustainable management of forests and enhancement of forest carbon stocks in developing countries) initiative has been conceptualised and operationalised as a scheme that results in the North-South flow of funds to incentivise the requisite sustainable forest management strategies in developing countries. It is a scheme through which developing countries are rewarded financially for any emissions reductions achieved associated with a decrease in the conversion of forests to alternative land uses. ${ }^{130}$ It was first negotiated under the UNFCCC in 2005 , with the objective of mitigating climate change through reducing net emissions of GHGs through enhanced forest management in developing countries. REDD+ negotiations during the various COPs of the UNFCCC have resulted in a plethora of Decisions that embody a comprehensive approach to mitigating climate change. In effect, REDD+ has the potential to contribute simultaneously to climate change mitigation and poverty alleviation, while also conserving biodiversity and sustaining vital ecosystem services. During the last two decades, various studies estimate that land-use change, including deforestation and forest degradation, accounts for about $12-29 \%$ of global GHG emissions. For this reason, reducing emissions from land-use change through the REDD+ mechanism is considered essential to achieve the objectives of the UNFCCC.

Although there is no direct reference to soil in the R-PIN, the document clearly identifies slash-and-burn agriculture in the context of fighting climate change as one of the main sources of deforestation and GHG emissions in Cameroon. The practice

128 See Republic of Cameroon (2012: 43).

129 Hannam \& Boer (2004: 1).

130 See the REDD Desk website at https://theredddesk.org/what-redd. 
of slash-and-burn is also one of the main drivers of soil degradation. ${ }^{131}$ In the same vein, Cameroon's REDD+ R-PP identifies slash-and-burn farming and extensive livestock breeding in the context of fighting climate change as one of the main sources of deforestation and GHG emissions in Cameroon. Slash-and-burn farming and extensive livestock breeding are also some of the drivers of soil degradation - they have as corollary the decrease in soil fertility and desertification. ${ }^{132}$ The R-PP further identifies bushfire as a source of soil degradation. The R-PIN and R-PP are therefore relevant for soil protection in Cameroon.

\subsubsection{Cameroon's National REDD+ Strategy}

Regarding soil protection, the National REDD+ Strategy clearly identifies the implementation of a programme on landscape restoration and management for climate change resilience in the Northern regions through the restoration of degraded soils by setting up private plantations for the production of wood energy; regaining soil fertility; and water catchment protection through agroforestry techniques. ${ }^{133}$ Within the framework of promoting sustainable agricultural systems, the National REDD+ Strategy makes recommendations for regaining soil fertility and water catchment protection through agroforestry techniques; promotion of food crops with low deforestation and forest degradation effects; promotion of agricultural systems that allow carbon conservation and sequestration (such as cocoa growing and coffee growing); promotion and propagation of improved seeds; promotion of certification of agricultural products; promotion of biofertilization through the recovery of agricultural residues; restoration and enhancement of village hedges around agricultural land; recovery of fallow land; and - for agro-sylvo-pastoral landscapes - support for pastoral landscape management (such as securing and improving pastures to reduce the incidence of bushfires).

\subsubsection{The 1995 Indicative Land Use Framework or Zoning Plan}

Soil constitutes a multiple-use resource requiring the harmonisation or coordination of users' interests, which are sometimes environmentally unsustainable and detrimental to soil quality. The indicative land-use framework or zoning plan - developed and adopted in 1995, aimed at the distribution of land use - makes provisions for

131 See Ministry of the Environment and Nature Protection \& FCPF (2008).

132 Forest Carbon Partnership Facility Cameroon (2013).

133 Cameroon's National Strategy for reducing emissions from deforestation and forest degradation, sustainable management of forests, conservation of forest and enhancement of carbon stocks, (national REDD+ Strategy), 2018. 
permanent forest estates. ${ }^{134}$ This is relevant for the protection of the soil covered by such areas. Permanent forest estates, as protected areas, are meant to remain forested. ${ }^{135}$ The zoning plan is believed to be inaccurate because of out-dated information and poor consultation with local communities. ${ }^{136}$ Although there have been attempts by government to institute a land-use policy, the efforts are not adequate, especially with regard to soil protection. A robust land-use plan needs to be put in place as a policy measure to respond to soil protection.

\subsubsection{Other relevant national policy instruments for soil protection in Cameroon}

Other important policy documents relevant for soil protection in Cameroon are the 1995 National Forest Action Programme, the 2035 Vision, the Poverty Reduction Strategy Papers (PRSPs) 2003-2010, and the GESP 2010-2020. ${ }^{137}$ As Cameroon presses towards becoming an emerging country by 2035 , the PRSPs and the GESP, both with a strong focus on ensuring that the rural sector becomes a key driver of the 2035 Vision, and the Rural Sector Development Strategy reinforce this ambition. To realise this, Cameroon intends to modernise its agricultural sector and focus on those value chains with huge potential to contribute to poverty alleviation and reduce ruralurban migration and unemployment in the rural areas. The realisation of these ambitions and objectives will put pressure on soil and are therefore potential soil degradation policy documents. In addition, there is the Cameroon's position paper for international discussions on climate change drawn up by the Ministry of Environment and Nature Protection in 2009, as it then was.

National policy frameworks, government strategies, action plans, etc., relevant to soil protection in Cameroon are anchored in the international policy instruments identified above, which all address the need for sustainable soil management. Regarding the LDN initiative, which is critical for soil protection, one notices that no legislation in Cameroon specifically captures it. Although Cameroon has no specific policy, plan of action or strategy on the implementation of the LDN concept, it is one of the

134 See Articles 1(2) and 6(2) of Decree No. 95/678/PM of 18 December 1995 to institute an indicative land use framework. In addition to Decree No 95/678, there are additional texts addressing zoning and land tenure, including: Decision No. 135/D/MINEF/CAB of 26 November 1999 establishing the procedures for the classification of the forests in the permanent forest areas of the Republic of Cameroon; Ordinances No. 74/2 and No. 74/1.

135 See the REDD desk Website, at http://theredddesk.org/countries/policies/indicative-land-useframework-cameroon, accessed 17 October 2017.

136 See Forest Legality Initiative website, at http://www.forestlegality.org/risk-tool/country/cameroon- 0 , accessed 31 January 2021.

137 GESP's first phase in the implementation of the long-term development 2030 vision, is a comprehensive and integrated strategic document, a springboard for all actions to be undertaken over the next ten years. It was prepared in a context marked by the increase in the cost of living at the national level, the financial crisis and the global food and energy crisis. 
countries that have been earmarked for the implementation of the LDN project. However, the NAP-FAD is comprehensive enough to address the objectives of the LDN. Thus, to an extent, Cameroon has explicitly and implicitly taken steps to establish policies, strategies, plans and programmes that accommodate the international policies.

\subsection{Relevant international law for the protection of soils}

National legislation and policies are in respect of international (global, regional and subregional) commitments subscribed to by Cameroon. At present, there is no specific international soil instrument despite an early proposal for a 'convention on sustainable use of soil' made in Tutzing, Germany, in 1998. ${ }^{138}$ However, existing international instruments contain provisions relevant to soil protection. Thus, international soil regulation is fragmented and dispersed, with no coherent and comprehensive approach to soil protection.

Regarding the transposition of international law into Cameroon's legal order, Article 45 of the Cameroonian Constitution as discussed in Chapter one above, is instructive. It stipulates that "duly approved or ratified treaties and international agreements shall, following their publication override national laws, provided the other party implements the said treaty or agreement". This constitutional provision seems to imply a direct reception and application of international law into the Cameroon's national legal system. Thus, as per Article 45 of the Cameroonian Constitution, the principle of 'direct applicability' otherwise known as 'direct effect', holds that international law is directly applicable as it is mainstreamed into the national legal order without the need of any national measures of transposition or reception. A corollary of the principle of direct applicability is the principle of 'primacy', according to which in case of any conflicting or contradictory provisions or incompatibility between international law and national law, the former prevails. This principle is well captured within the spirit of Article 45 of the Cameroonian Constitution.

Whether multilateral global or regional and subregional agreements, there is usually a distinction between international 'hard law'139 and 'soft law'140 instruments. Relevant international instruments for the protection of soil to which Cameroon is a signatory are presented under the following subsections.

138 See Boer et al. (2016: 56).

139 Hard law instruments consist of conventions, protocols, covenants, charters, pacts, constitutive instruments, final acts, etc. See Tamasang (2014: 29).

140 Numerous international initiatives have been taken in the area of environmental law and governance, leading to a body of soft law instruments consisting of declarations, resolutions, recommendations, Directives, statements, guidelines, stipulations, targets, decisions, plans, etc. See Tamasang (2014: 29). International environmental soft law or 'voluntary' standards have persuasive authority and may encourage States to act accordingly or may provide good legal basis for hard law instruments. 


\subsubsection{Relevant international soft law commitments}

Although not binding on state parties, soft law instruments have for the most part inspired most hard law instruments. Relevant international soft law instruments for the protection of soil to which Cameroon is a signatory are the following: The Stockholm Declaration, 16 June 1972; the Rio Declaration on Environment and Development and Agenda 21, 14 June 1992; The Future We Want - Outcome document of the United Nations Conference on Sustainable Development (Rio+20 Conference), 20-22 June 2012; the 2030 Agenda for Sustainable Development, instituting the Sustainable Development Goals (SDGs), 2015; and the Johannesburg Declaration on Sustainable Development, 2002.

\subsubsection{Relevant international hard law instruments}

Relevant international hard law instruments for the protection of soil to which Cameroon is a signatory are the following:

- The United Nations Convention to Combat Desertification, 1994;

- the Convention on Biological Diversity, 1992;

- the United Nations Framework Convention on Climate Change, 1992;

- the Kyoto Protocol to the United Nations Framework Convention on Climate Change, 1997;

- the Paris Climate Change Agreement, 2015;

- the Rotterdam Convention on Prior Informed Consent Procedure for Certain Hazardous Chemicals and Pesticides in International Trade, 1998 (as amended in 2004, 2008, 2011, 2013 and 2015);

- the Basel Convention on the Control of Transboundary Movement of Hazardous Wastes and Their Disposal, 1989;

- $\quad$ the Stockholm Convention on Persistent Organic Pollutants, 2001;

- the African Convention on the Conservation of Nature and Natural Resources, 1968 (revised by the Maputo Convention in 2003);

- the Bamako Convention on the Ban on the Import into Africa and the Control of Transboundary Movement and Management of Hazardous Wastes within Africa, 1991;

- the Convention for the Establishment of the African Centre for Fertilizer Development, 1985;

- the Phyto-Sanitary Convention for Africa, 1967;

- the Convention on the Prohibition of the Development, Production and Stockpiling of Bacteriological (Biological) and Toxin Weapons and on their Destruction. Opened for Signature at London, Moscow and Washington, 1972; 
- the Convention on the Prohibition of the Development, Production, Stockpiling and Use of Chemical Weapons and on their Destruction, Geneva, 1992;

- the Convention on the Prohibition of Military or Any Other Hostile Use of Environmental Modification Techniques, New York, 1976;

- the Convention on the Conservation of Migratory Species of Wild Animals, 1979;

- the Ramsar Convention on Wetlands of International Importance, especially as Waterfowl Habitat, 1971;

- the Cartagena Protocol on Biosafety to the Convention on Biological Diversity, Montreal, 2000;

- the Convention for Co-operation in the Protection and Development of the Marine and Coastal Environment of the West and Central African Region, 1981;

- the Protocol Concerning Co-operation in Combating Pollution in Cases of Emergency, 1981;

- the International Plant Protection Convention, 1951; and

- the African Charter on Human and Peoples' Rights, Banjul, 1981.

\subsection{Relevant national legal provisions for the protection of soil}

There is an absence of a comprehensive and coherent policy or legislation dealing with soil protection in Cameroon. In the absence of such comprehensive and coherent soil legislation, relevant legal provisions for the protection of soil are embedded within legal and policy instruments such as the Constitution; land tenure regulations; agriculture, environmental and natural resources policies; and laws, urban and spatial planning laws, laws relating to cross-cutting issues such as environmental and social impact assessment (ESIA), public participation, access to environmental information, rights to appeal administrative decisions and access to courts, etc. Thus, the Cameroonian legislative framework has a multitude of texts relating to soils. Although dispersed, such legislation prescribes mode of access to soils, manner of dispossession of land, and also use of land. These legislations contain relevant provisions for soil protection, but also incentivise soil degradation, demonstrating the strengths and weaknesses of such legislations in terms of sustainable soil management.

\subsubsection{The Constitution}

As the Grundnorm, the Constitution addresses important issues relating to national life in a concise manner and other laws then cover them in detail. But in the domain of soils, the drafters of the 1996 Constitution did not specifically envisage any provisions 
relating to soil protection. Thus, there is no direct or specific constitutional provision that deals with soil in Cameroon. However, when mentioning natural resources, ${ }^{141}$ we consider that this relates equally to soils. Such a conclusion is indeed plausible as allnatural resources have their springboard from the land or soils and so the exploitation of these resources has a bearing on soil protection. Incidentally, as indicated above, the Constitution does not address everything in detail, otherwise the legislative power would be rendered redundant or would have very little to do. Notwithstanding this observation, we should argue that soil, being a critically important cross-cutting subject, may require express articulation in the Constitution. In its Preamble, the Constitution provides that:

Every person shall have a right to a healthy environment. The protection of the environment shall be the duty of every citizen. The State shall ensure the protection and improvement of the environment.

These preambular provisions are a pointer to the fact that the Constitution expressly addresses environmental protection issues, particularly from a human rights perspective, and goes as far as to impose obligations on citizens and the state in connection with the enjoyment of such a so-called third-generational human right. Since the Preamble is now part and parcel of the Constitution, ${ }^{142}$ any violation of such a right is tantamount to a violation of the Constitution. An important question that begs for an answer at this juncture is whether the Preamble of the Cameroon's Constitution is binding or is merely aspirational. This question is answered by Article 65 of the Constitution which provides that the Preamble is part and parcel of the Constitution and thus is binding.

The legislative power does not have any specific express powers relating to the issue of environmental protection. However, the Constitution provides, among others, that legislation on natural resources is under the legislative power. ${ }^{143}$ Since natural resources form the basis of environmental resources, we can come to a safe conclusion that the Constitution envisages the legislative power's role with regard to environmental protection and by extension soil protection.

\subsubsection{Legislation on land tenure (landownership, access and users' rights) an} anchor point for soil protection

The right of ownership guaranteed by law enables the holder of the right to use and enjoy the proceeds or dispose of his property. No one is supposed to be deprived of

141 Paragraph 3 of the Preamble and Article 26(2)(d)(5) of Law No 96/06 of 20 January 1996 as amended.

142 Article 65 of Law No 96/06 of 20 January 1996 as amended.

143 Ibid.: Article 26(2)(d). 
this right unless on the grounds of public utility and on the basis that the owner is duly compensated in accordance with the modalities spelled out by law.

\subsubsection{Historical overview of landownership}

Landownership directly affects livelihoods and human development, both in urban and rural areas, making landownership a high-stake issue. Discussions here focus on landownership during pre-colonial, colonial and post-colonial periods in Cameroon.

Perhaps because of its low economic investment and commercial value, Belaunde et al. note that land in pre-colonial Cameroon was seldom the object of a scramble, and degradation - indeed, land during this period was owned communally by families or whole villages with traditional leaders acting as custodians for the benefit of all members of the village. ${ }^{144}$ These authors also emphasise that, under these conditions, land held significant religious value. As the burial place of generations of ancestors, land was a vital link to, and the primary means of communication with, the dead or ancestors. Within this context, land was handed down from generation to generation within the family and beneficial use rights were only granted to strangers temporarily if the family had no use for the land. ${ }^{145}$ The communal system of landownership was largely absorbed into a formalised landownership system with the coming of the colonial system.

Since 1884, following the German annexation of Cameroon until its Independence, Cameroon, like the rest of Africa, was under colonial rule, during which time the colonial masters' laws replaced many traditional or customary land tenure practices that were observed across the different fondoms and chiefdoms.

Under German rule for instance, the Crown Lands Act of 1896 granted state ownership over all lands, giving Germany the power to effectively occupy land and made native farmers wage labourers on German plantations. ${ }^{146}$ Thus, under German administration, only Germans could acquire land while the natives were deprived of such rights. ${ }^{147}$ The colonists confiscated most of the South West Region of Cameroon to establish industrial plantations. Traditional rulers resisted but the penalties for protesting were execution and deportation. ${ }^{148}$ However, the Crown Lands Act recognised customary ownership by excluding from the category of 'vacant land without owners', ${ }^{149}$

144 Belaunde et al. (2010: 18).

145 Ibid.

146 Ibid.

147 See Lemmens (2010).

148 Ibid.

149 Commonly referred to in Cameroon as terres vacantes et sans maître. 
land which 'private individuals or corporate bodies, chiefs or indigenous communities could show proof of ownership rights or other real rights over.' ${ }^{150}$

France, in contrast, used a system of land registration to formally establish the land rights of French citizens, while the natives retained the right only to occupy and exploit land in their native localities. Belaunde et al. state that, beginning with the French Decree of 1932, a process was established in which individuals could assert their claim over land usage. ${ }^{151}$ The land law of 17 June 1959 protected customary landownership stating $-{ }^{152}$

the customary rights exercised collectively or individually on all land are confirmed, apart from land which forms part of the public and private domains (...) and land which has been appropriated according to the regulation of the civil code or the registration system (...). No collective group or individual can be forced to cede their rights unless for a state-approved purpose and for which they receive fair compensation."

In urban areas natives were not allowed to live in the same areas as whites and were coerced to live in slums. ${ }^{153}$

During the British rule, British Cameroon was subdivided into two regions: British Northern Cameroon that applied regulations of Northern Nigeria, and British Southern Cameroon that applied regulations in use in Eastern Nigeria. Native Rights Decrees were enacted in 1927, enabling the Governor-General of Nigeria to confer statutory rights on non-natives and foreigners, and customary rights of occupancy to natives. In 1956, all lands became the property of customary authorities, except private land called 'freehold' and 'leasehold' lands. The rights of natives were protected by traditional rulers. The representative of the Crown, the 'Commissioner', was charged with ensuring the application of the law and protecting all native rights. The 'Public Land Acquisition Decree' enabled government to acquire land for public purposes. ${ }^{154}$

Thus, given its unique colonial history in Africa, Cameroon inherited a plethora of colonial land laws that have contributed to shaping the current legal regime governing landownership.

Soon after French Cameroon achieved independence in 1960 and the reunification of the French-speaking and English-speaking parts in 1961, two land tenure systems inherited from the colonial masters were established. The first attempt to harmonise the two inherited land tenure systems was on 9 January 1963, by decree, with the aim of laying down rules governing land tenure in Cameroon. The intention of the government was to replace the colonial concept of vacant land without owners with a national land law consisting of classical public and private land. Thus, the post-colonial era witnessed the establishment of modern statutory regulations in 1974 by the

150 Article 1.

151 Belaunde et al. (2010: 18).

152 Land Law of 1959, Article 3.

153 See Lemmens (2010).

154 Ibid. 
government of the newly formed state in an attempt to boost economic growth, enabling investors to buy and develop land. For this purpose, land was classified into three categories: private property, national land, and public land, guaranteeing free ownership and issuing of land to all naturalised persons and corporate bodies. Procedures and conditions for obtaining land certificates were put in place. The regulations also empowered the government to act as guardian of all land, thus allowing intervention to ensure the use of land. Regulations confiscated land under the control of native authorities. However, the 1974 land reform regulations appeared ineffective and inefficient, leading to a litany of subsequent legislation to facilitate the acquisition and development of land. ${ }^{155}$ While customary ownership rights were severely reduced under the 1974 land tenure ordinances, some use rights remained for the native populations. Specifically ${ }^{156}$

use rights are, in accordance with the relevant law, those which are recognised for resident populations to exploit all fauna and fish products in the forest, apart from protected species for their own personal use.

Thus, regarding struggles over land, key actors including 'traditional' authorities and natives (or their civil society representatives) continue to assert their claims based on customary law, which are, of course, recognised within the Cameroonian legal context. ${ }^{157}$ The multiplicity of legal instruments on land has implications regarding which forums are available to settle land disputes and also for the relative strength of claims over land. This current practice finds its roots in the pre-colonial and colonial eras. Pre-colonial rights over land were enforced by the traditional authorities that had decision-making authority over village affairs. The 1922 French Civil Code extended to Cameroon established a parallel system of adjudication under which 'natives' were governed by customary law and the modern French metropolitan administration applied to the assimilated Africans ${ }^{158}$ who had superior claims over natives. ${ }^{159}$ A similar practice exists today in Cameroon that tends to disfavour the poor and those without 'connections'. While Decree No. 77/249 of 15 July 1977 recognises the local customs of traditional chiefdoms, ${ }^{160}$ written law prevails over customary practice or claims in the event of any conflict. ${ }^{161}$ In brief, as noted by Belaunde et al., "legal pluralism in land law is well established in Cameroon, and the colonial legacy of land tenure reinforces power inequalities to the advantage of the State."162

155 Ibid.

156 Article 78 of the 1994 forestry law.

157 Belaunde et al. (2010: 19).

158 Commonly referred to in former French colonies in Africa as assimilés.

159 Belaunde et al. (2010: 19).

160 Article 6.

161 Supreme Court Decree 1962.

162 Belaunde et al. (2010: 20). 
The Government of Cameroon continues to maintain supremacy in landownership and uses, and defining, complex and expensive processes for private ownership. ${ }^{163}$ These costly and cumbersome procedures favour wealthy and well-connected individuals over marginalised people or those with little means. ${ }^{164}$ In effect, only those with enough resources or influence have been able to acquire land and enforce their land rights as competition for land increases. ${ }^{165}$ In Cameroon, statutory land tenure is thus considered superior to customary land tenure, although the latter was in existence long before the modern state. The conflict between customary and statutory land rights often culminates in the loss of land rights for the poorest and marginalised, with implications for land and soil degradation as they may use unsustainable methods to establish rights and claims to land.

\subsubsection{Modern landownership}

The Constitution of Cameroon guarantees in a general manner the right to ownership. This is affirmed in the declaration of general principles in the Constitution, through which ownership is defined as:

the right guaranteed every person by law, to use, enjoy and dispose of property. No person shall be deprived thereof, save for public purposes and subject to the payment of compensation under conditions determined by law.

Compensation is not, however, a pre-condition for imposition of environmental obligations, as the same Preamble imposes the responsibility on everyone to protect the environment without any condition. The enjoyment of this constitutional right to ownership in the domain of land is mitigated by the various legal texts relating to access to and use of lands or soils. Ownership of land is recognised for every physical or moral person through a certificate of ownership which in land matters is the land certificate. The conditions for obtaining such a document are not within the reach of the average citizen. The land certificate which is true evidence of landownership under Cameroonian land law is obtainable in three types of procedures depending on the origin of the land. This is well articulated below and is entitled "acquiring land under statutory law in Cameroon".

When it comes to landownership, access to and the use of land in Cameroon, public law on the subject is governed by the following ordinances: Ordinance No 74/2 of 6 July 1974 to establish the rules governing state lands; and Ordinance No 74/1 of 6 July 1974 to establish the rules governing land tenure. These are the texts governing land issues in Cameroon and they are complemented by several other enabling instruments

163 Ibid.: 18.

164 Ibid.

165 Ibid. 
such as Decree No. 76/166 of 27April 1976 to establish the terms and conditions for the management of national lands, and Circular No. 001/CAB/PM of 1 April 2014 relating to the provisions applicable to investors on access to land in Cameroon. These legal instruments may be read in conjunction mutatis mutandis with the following:

- Decree No. 2003/418/PM of 25 February 2003 to establish the rates for indemnities to landowners whose lands have farmlands and planted trees that have been destroyed on the grounds of public utility;

- Decree No. 87/1872 of 16 December 1987 to enable the application of law No. 85/009 of July 4, 1985 on expropriation on the grounds of public utility;

- Decree No. 214/32111 of 29 September 2014 to establish the minimum prices applicable to transactions on land that falls under the private property of the state;

- Decree No. 2014/3210/PM of 29 September 2014 to establish the conditions for the acquisition of BAUX and the modalities for payment of land taxes in economic areas;

- Decree No. 2014/3209/PM of 29 September 2014 to establish the minimum amounts for annual dues for the occupation of attachments to state lands;

- Decree No. 2015/3580/PM of 11 August 2015 to establish the modalities of registration and the regime of insurance and guarantees applicable to consensus and 'baux domaniaux';

- Decree No. 2016/3058/PM of 28 July 2016 to establish the rules for the use of land and construction;

- Arrête No. 00832/Y.15.1/MINUH/D000 of 20 November 1987 to establish the bases for calculating value of buildings that are expropriated on the grounds of public utility;

- Circular No. 001 of 22 March 1994 to establish the minimum amounts for the sale of national lands; and

- Law No. 85/09 of 4 July 1985 on expropriation for public utility purposes and the compensation regime.

To the above can be added Law No. 96/12 of 5 August 1996, a framework law on environmental management in Cameroon; and Law No. 94/01 of 20 January 1994 on forestry, wildlife, and fisheries regulations. The Cameroonian land-related legislative framework therefore constitutes multiple legal texts relating to soils.

Ordinance No. 74/1 of 6 July 1974, to establish the rules governing land tenure, throws more light on this distinction. After establishing the state as "guardian of all lands", to ensure the "rational use of land in the imperative interest of national defense or the economic policies of the nation" in Section 1(2), the ordinance divides land into three categories: Public lands, which consist of roads, rivers, the seaside and other lands for public use; private lands, which consist of privately held lands under title and private state lands ('domaine privé de l'Etat'). Private state lands include lands acquired by the state (e.g. to support public buildings), degazetted lands and rural lands 
left "unexploited or abandoned" by the owner or custodian as per Article 10 of Ordinance No. 74/2; and national lands, which is a residual category and consists of land that is neither private nor public, and is considered a land reserve. The law explicitly includes untitled lands occupied or used by rural communities as National Lands. This land is administered by the state "for the public good" and to "guarantee their use and effective exploitation" as per Article 14 of Ordinance No. 74/1. This distinction appears rather confusing to a foreigner who can hardly understand the gist of the distinction between public and private property of the state. One can imagine that this distinction is far from being logical in the sense that the state is a public structure and therefore the notion of private property of the state seems rather contradictory.

\subsubsection{Acquiring land under statutory law}

\subsection{Acquiring land from the national domain}

The acquisition of land in Cameroon occurs through a concession process, a procedure where the state authorises the acquisition by any person wishing to acquire land and who has a development project to undertake on an unoccupied portion of national domain. There are two phases, namely a provisional phase and a final phase. An application for a provisional concession is deposited at the Department of Lands. The divisional service head in writing informs the administrative authority of that division, the Senior Divisional Officer (SDO), who then convenes a consultative commission. This commission visits the locus in quo and subsequently forwards to the Minister of Land Affairs minutes with a reasoned opinion on the legal status of the land in question and feasibility of the project on such a piece of land. The applicant has five years to carry out developments on the land (the so-called mise en value) in accordance with a prescription of what is expected of the applicant (the so-called cahier de charge). The final concession is obtained only after the competent authorities are satisfied with the mise en value (effective use) of the portion of land previously under a provisional concession. In the event of non-respect of the obligations imposed on the concessionaire, he is divested of his rights on the piece of land and the concession comes to an end.

For obtaining a provisional concession, the procedure is as follows: Buying fiscal stamps; obtaining a certified copy of a national identity card; obtaining an Order to pay a fee for the opening of the file; paying the application fee for the file; depositing the application file for the concession; obtaining the Prefectoral Order for the visit to the locus; obtaining the Ministerial Arrête (Order) for the attribution of the provisional concession; and paying the land fee.

For obtaining the final concession, the procedure is as follows: Depositing the application of proof of mise en value; obtaining the convocation of the SDO for the establishment of proof of mise en value (effective use) of the piece of land; obtaining 
the Ministerial Arrête (Order) of the attribution of the final concession; obtaining an Order for the payment of the land fee; paying the land fee; depositing the application file for a land title/certificate; and collecting thereof.

\subsection{Acquiring private land of the state}

A private estate of the state can be attributed for use or for ownership to physical or moral persons. Sales documents for the private property of the state are valid only after the authorisation and visa of the minister in charge of state property and land affairs is obtained. Complete payments of the price after authorisation of the Minister gives the right to parcelling out or carving out or to transfering of the land title.

For obtaining ownership by way of sale by negotiation, the procedure is as follows: Buying fiscal stamps; obtaining a certified copy of a national identity card; obtaining an Order to pay a fee for the opening of the file; paying the application fee for the file; depositing the application file mutual consent; obtaining the Prefectoral Order for the visit to the locus; obtaining the Ministerial Authorisation for the sale of state land; obtaining an Order to pay the land fee; paying the land fee; depositing documents for the land title; and collecting thereof.

\subsection{Acquiring private land of an individual}

'Land title' is the official certification of landownership. Land transactions between private individuals can be done by way of transfer or by parcelling out. The transfer of land title is done after a complete cession, gratuitously or with obligations regarding the land. Still, the separation of the land following successive sales or division leads to parcelling out of the original title to the benefit of the acquirers.

Cameroonian land law prescribes that all land transactions be done through a notary officer. The notary officer is in charge of registration of documents of sale at the taxation office and of the transmission of application for land title to the Department of State Property and Land Affairs. In Cameroon a land certificate, which is the only proof of landownership, can be obtained by the signing of a land transfer agreement, a Deed of Conveyance, ${ }^{166}$ and eventually the issuance of a land certificate. Generally, an individual or a moral person desirous of owning land in Cameroon has a duty to consult a property attorney to conduct due diligence and investigate the title of the land at the property land registry so as to ensure that the land is free from all encumbrances

166 A deed of conveyance is a legal document prepared by a notary public to convey absolute rights over a piece of land to a purchaser as per Section 8(1) of Ordinance No 74/1 and Section 74 of Law No. 90/059 of 19th December 1990. 
like bank mortgages, court cases, double sales, etc. A notary public is statutorily commissioned to draft and sign all deeds of conveyance in Cameroon after conducting a survey site plan of the parcel of land to ascertain the square metre area of the land or documents evidencing initial sale. The Cameroon Penal Code sanctions any vendor who does not make full disclosure at the negotiation stage before selling the piece of land as per Section 318 of the Cameroon Penal Code.

The law regulating the granting of a land certificate in Cameroon is Decree No. 76/165 of 27 April 1976, which has been modified by Decree No. 2005/481 of 16 December 2005. Landowners mistakenly consider their notarised Deed of Conveyance to be a land certificate. The procedure to obtain a land certificate is strict and detailed. A summary of the procedure comprises an application with attached survey plan describing the land, payment of a processing fee, a visit to the locus for boundary demarcation and cadastral mapping, publication and the eventual issuance of a land certificate.

For obtaining a land title following a transfer, a technical file for transfer must be obtained which requires the following procedure: Buying of fiscal stamps; buying a form for the technical file; depositing the application for obtaining of the technical file for transfer; obtaining the state of cession of survey department; paying the survey fee; and collecting the technical file/dossier.

For the Preparation of the technical file of transfer, signature of Sales Act and collection of land title require the following: Applying for urban certificate; collecting of urban certificate; signing of sales acts at the notary office; obtaining a receipt of deposit of the application of land title; and collecting of the main land title clearly marked 'transfer'.

Obtaining a land title after a parcelling out process and /or obtaining the dossier techniques of parcelling out requires: Buying of fiscal stamps; buying of a form for the technical file; depositing of an application for obtaining the technical file for transfer; obtaining the state of cession of the survey department; paying the survey fee; and collecting the technical file/dossier.

Generally, land titling is fraught with stringent bureaucratic procedures and inefficiencies. The acquisition and establishment of a land certificate is a slow process because of stringent legal requirements, and a cumbersome and costly procedure. Cameroon's land tenure law creates a certain degree of uncertainty regarding tenure rights. Modern landownership under state control is unfair, being beneficial to the state, large corporations, the church, national elites and the rich. ${ }^{167}$ This can encourage

167 See Divisional Officer of Ndop v Yenkong, (1994) CAJ-CLC 56; C. Chekeba v Divisional Officer of Mezam. (1994) CAJ-CLC 18. (1994) CAJ-CLC 18; also see Martin Fobuzie v SDO Mezam BCA/2/78 unreported decision of the Bamenda Court of Appeal. Cited by Munge (2011: 209). 
unsustainable practices by occupiers of land who feel unsecured - which is not healthy for soil protection.

\subsubsection{Traditional law}

Traditional/customary law governs land tenure in Cameroon, as in the rest of Africa. The country has more than 250 ethnic groups, each with its own customs, ${ }^{168}$ making the country rich in traditional/customary law. In the area of land tenure, customs recognise customary ownership of land. Such customary tenure was recognised by Ordinance No. 74/1 up to 5 August 1974, but the same legislation stated that, after this date, all lands under customary ownership should be registered or cease to exist under customary tenure. ${ }^{169}$ Therefore, according to statutory law, there has been no customary ownership of land after 5 August 1974, and this has been one of the major sources of conflict over landownership in the country. In this regard, the majority of lands in Cameroon are classified as national and state-owned despite century-old claims by communities.

\subsubsection{Conflicts and means of conflict resolution}

In Cameroon, there is a variety of land tenure types including state-owned lands (public lands, private state lands and national lands), private lands and lands owned communally by communities, all of which fall under the two broad classifications of statutory and customary land tenure. These different tenure types constitute a source of conflict and unsustainable land and soil management. The majority of civil cases that come before Cameroonian courts today have their root causes in land and land-related conflicts. This means that land has been and continues to be the critical and core resource and deservedly may be referred to as the bedrock resource. In case of conflicting claims over land, ownership is ascribed to the person that can prove better title to the land. If there is no title document, it is sufficient for a claimant to show that they have been in possession of the land. Evidence of possession includes, but is not limited to, cultivation on the piece of land, erection of buildings or fences, and demarcation of the land with pegs or beacons. The purpose of a survey plan in a land case is to identify the land in dispute because a person who cannot identify a piece of land will hardly convince the court of being the rightful owner. Traditional evidence can also be

168 Ngwafor (1996).

169 Article 17(2) of the Land Tenure Ordinance, 1974 read in conjunction with Article 15 classifying land into two categories. 
adduced to prove 'ownership' of land, but the court must be convinced as to who founded the land, how the founder founded the land, and the names of intervening owners.

Resolution of disputes over land falls under the jurisdiction of ordinary law courts or courts of ordinary jurisdiction. The judicial organisation for Cameroon according to the 1972 Judicial Organisation Ordinance as amended in 2006 and 2011 is as follows: At the top, there is the Supreme Court, followed by the Court of Appeal in every region, the High Court in every division, the Court of First Instance in every sub-division and, finally, there are the Traditional or Customary Courts, where applicable. Every Cameroonian citizen who feels that his/her rights have been violated in a land transaction can solicit the appropriate court in their place of residence.

\subsubsection{Public environmental law}

Public environmental law in Cameroon refers to soil-specific legal acts, environmental law, nature conservation legal acts, subsidiary regulations on environmental thresholds, environmental quality standards, etc. and international law (bilateral and multilateral agreements) and their relevant provisions concerning soils.

\subsubsection{Soil-specific legal acts}

Decree No. 2011/2584/PM of 23 August 2011 on the modalities of protection of soils and sub-soils is the one and only Cameroonian text focusing specifically on the protection of soils and sub-soils. This can be verified in Article 3, which stipulates that "any activity relating to the exploitation of the soil must be done in a manner as to avoid or reduce erosion of soils and desertification". In addition, this decree specifically takes into account lands suitable for agricultural activities. Thus, the protection of arable land is envisaged in Article 5 in the following words: "is forbidden any activity which degrades or modifies the quality and/or the structure of arable lands or contributes to the loss of such lands". Decree No. 2011/2584/PM is an enabling instrument to Law No. 96/12 of 5 August 1996 on framework law on environmental management. The administration in charge of environment is tasked with overseeing the implementation of this legal text. It therefore has to ensure the respect of this piece of legislation, as need be, and to impose administrative sanctions in cases of violation of the text. The decree is even more specific regarding the protection of soils and subsoils to the extent that it particularly preserves risk zones. This is the purport of Article 4(1) which prohibits the exploitation of zones with high risk of erosion. Article 4(2) prohibits any activity that degrades or modifies the quality and/or structure of arable lands or which contributes to the loss of these lands. On the issue of environmental 
impact assessment (EIA), it is important to note that although the realisation of all development projects is conditional upon the carrying out of EIA, this prescription has already been envisaged in the Framework Law on Environmental Management. The decree has retaken the provisions in order to make this prescription emphatic and to ensure further sensitisation to a better protection regime for soils and sub-soils. This is what seems to be the purport of Article 9, which provides that:

all physical or moral persons, private or public who undertake agricultural exploitation and practice intensive use of fertilizers and/or pesticides or apparatuses that condition the soil, are obliged to carry out in a regular manner an evaluation of their impacts on the environment in accordance with regulations in force

and Article 10 which provides that:

all physical or moral persons desirous to manufacture or condition fertilizers and/or pesticides on the national territory are obliged to carry out environmental and social impact assessment in conformity with regulations in force.

There is no gainsaying from the foregoing provisions that environmental and social impact assessments (ESIA) are mandatory under Cameroonian law for any project likely to have deleterious effects on the use of soils. The question remains that of effective implementation of the rules on ESIA. Are the rules strictly respected by the stakeholders? To this question, the answer may be in the negative. Again, does the administration in charge of the environment control project implementation in order to ensure compliance with the undertakings by project promoters (commonly referred to in Cameroon as cahier de charge)? We will say that the administration does carry out control, but such a control is usually tainted with corrupt practices as the promoter may grease the palms of the environmental inspectors or controllers, thereby making them biased in their report. This, as a matter of fact, does not augur well for sustainable soil management. Furthermore, where a report identifies violators anyway, the question is whether such violators are sanctioned? Sanctions for violations are administrative and judicial. From an administrative point of view, there is ample evidence that, once identified, the administration sanctions the violators of soil and soil-related legislation. Another disturbing issue has turned on whether the sanctions are sufficient to have a deterrent effect on violators. Most of the cases that go to court are protracted and generally the sanction is not in favour of the administration for at least two reasons. The one is that judges are not sufficiently schooled in this relatively grey area of the law and, second, even when they are, some will give in to corrupt practices. Even when the violators are sanctioned, it has been argued that the sanctions are not heavy enough to deter violators. Again, the provisions above aimed at users practising intensive use of fertilizers and pesticides or apparatus that condition the soil seem impractical because, if read as they stand, any user of pesticides would have to conduct an ESIA. This seems unrealistic. However, the decree specifically mentions 'intensive use' of fertilizers and/or pesticides or apparatus that condition the soil. This may be interpreted to mean that users who do not practise intensive use are not required to carry out ESIA. Nevertheless, their activities may still lead to soil degradation if the sum total of their 
small-scale projects are taken into account. In the absence of a comprehensive and coherent soil law, the relevant provisions of environmental law, as supplemented by other subsidiary regulations on environmental thresholds and environmental quality, govern soils in Cameroon.

\subsubsection{Environmental law, relevant provisions concerning soils}

In Cameroon, protection of the soil and subsoil is envisaged in Law No. 96/12 of 5 August 1996 relating to the framework law on environmental management and its enabling instrument which is Decree No. 2011/2584/PM of 23 August 2011 Establishing the Modalities for the Protection of the Soil and Subsoil as discussed above. The direct provision of the 1996 Framework Law on Environmental Management is Article 36 which provides that:

(1) the soil and subsoil, as well as the limited renewable or non-renewable resources contained therein, shall be protected against any form of degradation and jointly managed rationally by the competent Administrations; and

(2) an enabling decree of this law, prepared in collaboration with the Administrative units concerned, shall lay down:

- the specific conditions for the protection and fight against desertification, erosion, loss of arable land and pollution of the soil and its resources by chemicals, pesticides and fertilizers;

- the list of fertilizers, pesticides and other chemical substances whose use shall be authorised or encouraged in agriculture;

- the authorised quantities and the terms and conditions for their use so that the substances do not endanger soil quality or other receptor environments.

With respect to this specific provision of the law, we can praise the fact that the enabling instruments are in force and the only regret is that, like many other instruments, its effective implementation is still doubtful as some unauthorised chemicals and pesticides are still used for agricultural activities thereby degrading the soils and subsoils by way of pollution and other means. There is therefore the need to enhance the implementation of legislation in order to ensure that soils are properly protected.

According to Article 37 of the 1996 Framework Law on Environmental Management, holders of mining or quarrying permits are required to rehabilitate the exploited sites. With regard to this provision, there is good reason to commend the intentions of the legislator for the simple reason that, as one of the mineral destinations in Africa, Cameroon hosts many multinational companies carrying out exploration and exploitation in the extractive sector, especially in the domain of hard minerals. Consequently, the soils are exposed after these activities have taken place and therefore there is the need to rehabilitate. Unfortunately, subsidiary/delegated legislators have not moved the legislative crafting agenda forward as the enabling instruments to the application of this provision relating to soils have not yet seen the light of day in spite of the fact that mining activities have taken place and are still taking place and the soils are 
exposed to erosion to the same extent as they pollute. The regret is even greater because the law is 23 years old, having entered into force in 1996, and some of its enabling instruments have not yet come into force.

It is important at this point to say a few words regarding the critical issue of enabling instruments in the particular context of Cameroon. The legislative crafting process in Cameroon is one that is significantly inspired by the Continental legal system. Such a legal tradition practices a law-making process where parliament, or any other organ of state entrusted with powers to make laws, crafts a piece of legislation by setting out the main issues of the law and allows subsidiary or delegated legislators to lay down details to complete such a legislation. These details have the following ingredients, namely: clarifying/defining of concepts, phrases and words contained in the main legal instrument; creating institutions for the implementation of the law; outlining the procedure that may be necessary for the effective implementation of the law; and taking any other measures that may be necessary for a complete understanding of the law. The obvious merits of such a legislative crafting process is that: the main piece of legislation itself is not overloaded; it eases understanding and avoids ambiguity in the understanding and interpretation of the legislative piece; it makes for sufficient flexibility in the law-making process as delegated legislators are involved especially from a technical perspective; it saves parliamentary time and obviates boredom; and makes allowance for some urgent matters to be addressed without necessarily convening parliament for the purpose. Despite these advantages, the ugly side of such a process is that legislative implementation is unnecessarily delayed because an enabling instrument has not seen the light of day. The executive power which is usually in charge of putting in place an enabling instrument may deliberately delay the implementation of a law requiring the former probably because that law was not the brainchild of the government, for instance, where a funding institution from which funds are sourced, such as the World Bank or the International Monetary Fund, imposes a conditionality for the grant of a loan. In fact, the absence of an enabling instrument makes the implementation of a piece of legislation practically difficult, if not impossible. It is therefore recommended that enabling instruments should be crafted at the same time as the main law.

Relevant provisions of the 1996 Framework Law on Environmental Management for the conservation of nature, which by extension protects the soil, include: Article 38 regarding the allotment and management of land for agricultural, industrial, urban or other uses, as well as prospecting, research or exploitation of subsoil resources likely to endanger the environment; Article 62 regarding the protection of nature, the preservation of animals and plant species and their habitats, the maintenance of biological balances and ecosystems, and the conservation of biodiversity and genetic diversity against all causes of degradation; Article 63 regarding the rational management of natural resources; Article 64 regarding the sustainable use of biodiversity; Article 65 regarding the exploitation of biological and genetic resources; Article 66 on the 
recognition and protection of historic, archaeological and scientific sites, as well as sites that are of special panoramic beauty; Article 67 regarding the rational and ecological exploitation of mining resources and quarries in line with environmental considerations; Article 68 regarding protection of land against erosion and prevention and fighting against desertification; and Article 69 requiring states to use shared resources in a sustainable manner and in accordance with international conventions signed between the states sharing such resources.

Natural resources, nature and biodiversity conservation are properly addressed in environmental texts relating thereto as seen in the provisions above. This is not surprising given the fact that the legislation in question is a framework law. Soils form the bedrock of natural resources and nature, including biodiversity. A reading of the environmental legislation above relating to these aspects reveals that sufficient measures are in place to protect soils and soil-related elements which are the habitats of nature and biodiversity resources. Furthermore, while there is ample evidence of national policies on the subject of soil protection, the environmental legislation has gone a step further to put an assent on the application of international conventions duly ratified by Cameroon in keeping with Article 45 of the Constitution given earlier. Cameroon has ratified most, if not all, of the relevant international conventions on soil and soil-related issues. What's more, the country is in the implementation phase of national legislation and international conventions, but with obvious challenges which we think could be addressed in model legislation.

MINEPDED, which is the administration that spearheads the application of this law, encounters many difficulties in its mission of ensuring the protection of the soil and subsoil. In effect, in the organisational structures of many other public administrations, we find some internal services that are specifically in charge of environmental concerns. These services carry out their missions without necessarily seeking the opinion of the ministry in charge of the environment. It is this state of affairs that generally leads to soil degradation in our country. For example, in matters of mineral exploitation or any other industrial activity that affects the soil, MINEPDED requires that all such sites should be returned to their initial state or be restored. This requirement is seldom respected by industrial operators and MINEPDED is handicapped in taking any effective measures against the recalcitrant operators because the industrial activities carried out on these sites do not fall within the area of competence of MINEPDED. The attitudes of these ministries do constitute, in most of the cases, the root causes of the conflicts between the local populations and the industrial operators. This justifies the need for collaboration and coordination among centralised and decentralised territorial collectives. In addition to the aforementioned legal texts, one still finds provisions relating to the protection of soil and subsoil in other legal instruments. 


\subsubsection{Nature conservation}

In Cameroon, there is not specific legislation with the direct objective of protecting nature apart from the Framework Law on Environmental Management discussed above. However, there are other sectoral legal texts that deal with the conservation of nature and, by extension, soil protection.

\subsection{Law No. 98/005 of 14 April 1998 (Water Code)}

With regard to the protection of soil, the following provisions are relevant. Article 2(1) requires the state to ensure the protection of water. Article 4(1) prohibits the emptying, shattering, disposal, infiltration, leakage, direct or indirect deposit into waters of any solid material, liquid or gas, and, in particular, industrial, agricultural and atomic wastes if these are susceptible to: altering the quality of the surface or underground water or the high seas within territorial confines; endangering public health or aquatic or submarine flora and fauna; or compromising the economic and tourism developments of the regions. Under Article 4(2), the minister in charge of water may, after inquiry and opinions of other ministries concerned, authorise and regulate the forms of disposal indicated above, with the possibility of modifying or withdrawing such an authorisation. Article 7, in an attempt to protect the quality of water destined for use, sets a perimeter of protection around the capture points, treatment and stocking points of the water and declares lands found within the perimeters of protection to be of public utility.

The Water Code, which is also a sectoral law, does not ignore soil and soil-related concerns which are addressed not directly but by implication. What matters here is that the water legislator has demonstrated the importance of soil in the water management regime given that water has its source from the soils. Therefore, the soils must be protected if the goal is to ensure access by everyone to water resources either for domestic or industrial uses. In relation to effective water management, we submit that, as a matter of principle, the Water Code and its enabling instruments seem to have captured all the stakes that the exploitation of water may have on soil protection. Since water has its source from the soils, the sustainable exploitation of water by implication means the protection of soils.

\subsection{Law No. 94/01 of 20 January 1994 on Forests, Fauna and Fisheries Regulation}

Law No. 94/01 is the basic law governing forest exploitation in Cameroon. Desertification and deforestation constitute some of the phenomena that contribute to soil 
degradation. In effect, when trees are cut without being replaced, the space left behind becomes a stretch of desert. The soils become exposed with attendant consequences. It is in this light that this law makes provision for reforestation and reinstatement of the exploited species. Unfortunately, this requirement is hardly respected especially by clandestine forest exploiters. The state, civil society organisations and partners in development have embarked on a mission to combat this ill through the introduction of licensing and certification procedures in forest exploitation.

3.3.3.4 Subsidiary regulations on environmental thresholds, environmental quality standards, and more

A document relating to the norms of environmental protection has been elaborated upon and is in the process of homologation at the Norms and Quality Agency.

Apart from the Framework Law on Environmental Management, there are other subsidiary regulations on environmental thresholds and environmental quality standards that are equally relevant for soil protection in Cameroon. These include: Law No. 89/027 of 29 December 1989 on toxic and hazardous waste that binds local industries, which by their activities generate toxic and/or dangerous waste, to declare the volume and the nature of their production and to ensure their safe disposal for man and his environment; Law No. 98/015 of 14 July 1998 and its implementing regulations notably Order No. 013/MINMEN/DMG/SL of 19 April 1977 on the nomenclature of establishments classified as dangerous, unhealthy or uncomfortable, as modified and completed by Order No. 02/MINMEE/DMG/SDAMIC of 14 January 1999; Decree No. 99/818/PM of 9 November 1999 laying down the procedures for the establishment and operation of establishments classified as dangerous, unhealthy or uncomfortable; Decree No. 2011/2581/PM of 23 August 2011 regulating harmful and/or dangerous chemical substances; and Decree No. 2012/2809/PM of 26 September 2012 laying down provisions for the sorting, collection, storage, transport, recycling, treatment and disposal of waste. The purpose of these texts is to guarantee environmental and public health protection by establishments considered dangerous, unhealthy or uncomfortable; and Decree No. 2000/092/PM of 27 March 2000, amending Decree No. 95/531/PM of 23 August 1995 setting the terms and conditions of application of the forest regime; Decree No. 95/466/PM of 20 July 1995 to set the terms and conditions of applying the wildlife regime; Decree No. 95/531/PM on the role of ministry of forestry staff to determine modalities for safe and controlled fire, and ministry of territorial administration and decentralisation to issue permits to start fires after consultation with local forestry staff; Decree No. 95/678/PM of 18 December 1995 establishing an incentive framework for the use of Southern Forest Areas and Circular Letter No. 92/LC/MINFOF/SG/DF of 23 September 2009 on procedures for the issuance and monitoring of recuperation of timber permits and selected logging. 
The aforementioned legal texts all seek to prevent deforestation and wildlife extinction or the destruction of wildlife habitats. The protection of these ecosystems indirectly also protects their soils.

\subsubsection{Environmental monitoring}

Environmental monitoring is of fundamental importance to effective environmental management, ${ }^{170}$ especially soil protection. With regard to soil, environmental monitoring may be referred to as the systematic sampling of soil in order to establish the ecological state of the soil; to assess the effects of dangerous activities on soils; to ensure compliance with environmental regulations; and to inform policy design and decisionmaking. Environmental monitoring and compliance is carried out through EIA, which is defined as a way of tracking and addressing changes in the biophysical and social environment during project implementation. ${ }^{171}$ In its organisational framework, the ministry in charge of the environment has a service dealing with environmental monitoring. In effect, this service in respect of ecological monitoring and follow-up of climate has the mission to conceive and put in place an ecological survey and alert system; elaborate on, establish and follow-up on programmes relating to climate change; develop strategies of environmental surveys; formulate and put in place the policy for information concerning the environment, nature protection and sustainable development; manage the systems of geographic information on the environment, nature protection and sustainable development; serve as liaison between the networks and information systems existing in the environmental sector, nature protection and sustainable development, both at the national and international level; put in place and animate a platform for information-sharing between the focal points of international agreements and conventions in matters of environment, nature protection and sustainable development; centralise data relating to information and documentation in all sectors of the environment; and participate in the prevention and management of natural or anthropic disasters.

See, generally, Article 45 of Decree No. 2012/431 of 1 October 2012 relating to the Organization of the Ministry of Environment, Protection of Nature and Sustainable Development. Environmental monitoring is contained in Law No. 96/12 of 5 August 1996 relating to the Framework Law on Environmental Management, notably through one of its enabling instruments being Decree No. 2013/0171/PM of 14 February 2013 establishing the conditions for environmental and social impact assessment. Under Cameroonian EIA regulations, Environmental Management Plans (EMP) formullated during the impact assessment (IA) process are subject to administrative and technical 
surveillance as defined by Article 27 of the 2013 decree on ESIA. This decree not only requires EMP implementation, but demands the production of semester reports by bodies or companies for projects whose implementation has been subjected to IA. These are all relevant for sustainable soil management and protection. This text in Articles 27,28 and 29 makes provision for environmental monitoring of projects which implicitly protect the soil. Article 29 gives the latitude to the administration in charge of the environment to make use of recourse to any expertise in order to ensure the effectiveness of the environmental assessment. Thus, environmental monitoring can be conducted by stewardship organisations, concerned individuals, non-governmental environmental organisations, private consulting firms, and government agencies.

\subsubsection{Execution of the law}

The executive arm of government executes or implements the law at the various central and decentralised levels of the administration with the help of law enforcement agents. Government departments ${ }^{172}$ are in charge of executing the law at the central level, while regional entities, ${ }^{173}$ local councils ${ }^{174}$ and traditional authorities ${ }^{175}$ oversee the executing of the law at the decentralised level. It should be noted that the decentralised entities referred to above operate within institutional arrangements created by the law, and the question is: Do such arrangements ensure effective collaboration and cooperation that can enhance sustainable management of resources, including soils? This does not seem to be the case as the transfer of competence and management of resources is not total. The government departments overseeing territorial administration continue to control the activities of decentralised entities, rendering the implementation or execution of projects a difficult task.

\subsubsection{Enforcement issues}

One of the difficulties in matters of soil protection is the issue of enforcement of existing legislation. In effect, without prejudice to the prerogatives of the public prosecutor and the judicial police vested with general enforcement competence, the officials under oath in every administration, especially those of the cadastral survey, town planning, public works, forests, merchant, mines, industry, labour and tourism services, are responsible for the application of all the regulations in force in every sector of activity

172 Article 57(2).

173 Law No. 2004/019 of 22 July 2004 fixing the rules applicable to regions.

174 Law No. 2004/018 of 22 July 2004 fixing the rules applicable to councils.

175 Decree No. 77/245 of 15 July 1977 to organise Chiefdoms. See articles 19, 20(1) and (2) and 21. 
to which they are party or are connected. In this respect, they oversee the research and establishment of infringements in view of implementing the legal framework governing their domain of interest. This is contained in Article 88 of the 1996 Framework Law on Environmental Management. Similar provisions can be found in Article 202(1) of the Mining Code. ${ }^{176}$

\subsubsection{Competences of enforcement entities}

As stated above, each administration controls its domain of competence. Every administration has a control service. In the administration overseeing the environment, there is an environmental inspection brigade. This unit is in charge of identifying acts that violate the environment. The organ is made up of a body of environmental inspectors and controllers. The environmental brigade is not in charge of administrative monitoring but may be solicited after administrative monitoring where public agents discovered serious environmental violations.

\subsubsection{Available and accessible data}

The ministry in charge of the environment in Cameroon possesses in its organigram a Centre for Information and Environmental Documentation (Centre d'Information et Documentation sur l'Environnement). The centre oversees the collection, stocking and dissemination of information relating to the environment. The centre is also equipped with many clearing house mechanisms (CHMs). The number of these CHMs depends on the number of multilateral environmental agreements ratified by the State of Cameroon and whose implementation requires the use of a CHM. The ministry in charge of the environment also has a website which publishes important information relating to its domain of competence. As a matter of principle, information and data relating to the environment in Cameroon is transparently available to everyone. But information on soil is not available on the website.

\subsubsection{Sufficient expertise and support by research institutions}

For a good number of years now, many research institutions have created study centres in various branches of the environment. It is in this light that we see both state universities and private institutions providing training in matters relating to the environment.

176 Law No. 2016/017 of 14 December 2016 repealing Law No. 001 of 16 April 2001 establishing the Mining Code and its modification by Law No. 2010/011 of 29 July 2010. 
Despite the availability of persons trained in matters relating to the environment, the administration in charge of the environment is unable to employ all these persons with good skills in the job market. It is true that the private sector increasingly searches for experts in this domain, but unfortunately the number of experts recruited by this sector still remains modest. In research, state universities are leading in matters of environmental research. The administration in charge of the environment sometimes makes use of recourse to the expertise of these institutions or to their research centres.

\subsubsection{Staff and technical equipment}

MINEPDED was created in 2004 and, since 2012, had a new organigram. To date, many of the offices created within that organigram have still not been occupied. This situation is explained by an insufficiency of personnel. This relatively new field or domain thus faces the challenge of limited personnel. Many explanations may be advanced for this state of affairs, such as MINEPDED does not have a legal framework relating to the professional corps on the environment; training institutions in the various branches of the environment were created in the distant past, and the public service at some point temporarily halted recruitments.

As concerns the technical teams, MINEPDED is lagging behind. This administration which was only recently created was primarily preoccupied with the establishment of its institutional framework, the sensitisation of citizens on matters relating to the environment, and the stakes involved. A whole team was constituted for the realisation of environmental inspections and control, but because they were not renewed, these teams are today obsolete. The administration in charge of the environment is in deep need of technical equipment, as well as training of personnel to use the equipment.

\subsubsection{Science-policy interface of soil data/information}

Scientific data and information are the basis for sustainable soil management and are critical in informing policymaking, but such scientific data on sustainable soil management in Cameroon are not known to the general public. In addition, scientific data on soil status and actual soil degradation or potential degradation threats in the country are limited and not publicly available. Regarding agriculture in particular, scientific information on sustainable soil management is not made available to farmers, especially small-scale farmers who continue to indulge in unsustainable agricultural practices which are detrimental to soil health. Improved and sustainable soil management therefore needs data that speaks of soil degradation and the involvement of scientific institutions through the data they generate from research, which could inform options for model legislation. Within the framework of the science-policy interface, quantified 
and qualitative soil data and information should be scientifically verified, requiring data collection (generation), analysis, validation, reporting, monitoring and integration with other disciplines.

Generally, the legal requirements and institutional structures for environmental monitoring exist in Cameroon, but their implementation is limited because of weak capacities and conflicts with other sectors owing to poor coordination. Other associated reasons are the lack of EMP implementation follow-up on the part of the administration due to constraints in financial resources allocated to monitoring missions and the unavailability of validated environmental monitoring and compliance methodology for the different industry sectors. ${ }^{177}$ Limiting soil degradation requires constant monitoring and regular environment audits, but a robust monitoring system to monitor soil degradation is absent and there is little research or information available about soils. Scientific information is the basis of sustainable soil management, but such scientific information on sustainable soil management in Cameroon is not known to the general public, especially not to small-scale farmers. Environmental monitoring is weak and therefore sustainable soil protection is not promoted. Another major weakness is that different ministerial departments are working from different land-use maps with many hectares of land having more than one land-use status, which is an incentive for soil degradation. In a sustainable context, licences for land use should only be allocated within the appropriate land-use category, but at present this is weakly monitored and enforced, partly as a result of the fact that land-use planning and zoning is inadequately designed. There is also no appropriate body with the power to exercise monitoring and enforcement prerogatives. This could put areas of highly vulnerable soil at risk of degradation.

Furthermore, environmental monitoring in Cameroon is weak and therefore does so far not enhance sustainable soil protection. The current land planning regulatory framework makes it challenging to protect soils, and there is therefore a need for regulatory reforms that would make it easier for project implementers to engage in sustainable activities that protect soils. The main requirements for the monitoring arrangements are that they should be independent, accountable, sustainable, and performed to a reasonably high scientific standard. International NGOs and research institutions have an important role to play in setting up such a monitoring system, including building the capacities of the different stakeholders in monitoring. This is critical in putting any sound management in place. A crucial monitoring criterion with respect to soil protection is the establishment of an appropriate body with the power to exercise monitoring and enforcement prerogatives. 


\subsubsection{Cross-cutting issues}

The need for EIAs, provisions of public participation, access to environmental information, and rights to appeal administrative decisions (access to courts) are some of the cross-cutting issues that underpin soil protection in Cameroon. Their poor implementation is also an incentive for unsustainable soil management that can drive soil degradation.

\subsubsection{Need for environmental impact assessments}

Prescribed by many international legal instruments both of soft and hard law characters ${ }^{178}$ Environmental impact assessment is the systematic review of whether or not a project has adverse effects on the environment. The Framework Law on Environmental Management enforces the prescriptions in Article 17(1) - which requires the promoter or owner of any development, labour equipment or project which may endanger the environment owing to its dimensions, nature or the impacts of its activities on the natural environment - to carry out an EIA in order to determine the direct or indirect effects of the project on the ecology of the zone where the plant is located or other region, the physical environment and quality of life of the populations, and the impact on the environment in general. Under Article 18, an EIA that does not comply with the prescriptions of the specifications will be null and void.

To facilitate the understanding and application of the abovementioned provisions of the law, Decree No. 2013/0171/PM of 2013 lays down rules for conducting ESIA. We notice an innovation in this enabling instrument which introduces a social dimension to the impact assessment process. Another development in this regard came in 2016 with two Ministerial Orders: one to elaborate on the categories of operations subject to ESIA and strategic environmental assessment and the other to define the contents for modelled terms of reference. Given that this is a cross-cutting issue, the grant of a Certificate of Environmental Conformity by the minister in charge of the environment is informed and opined by an Inter-ministerial Committee on the study of the application files for ESIA.

We do not hesitate to state that the effective implementation of the abovementioned legal instruments is fraught with challenges ranging from ineffective public participation, to inadequate personnel and over-centralisation, corruption, and inadequate monitoring by the administration in charge of the environment. Of course, this does not augur well for effective soil protection and the environment in general. Some researchers have highlighted that the conduct of most EIAs is usually on demand by

178 Such as the Rio Declaration on Environment and Development, 1992; the Convention on Biological Diversity, 1992; etc. 
development assistance agencies on a project-by-project basis, not as a response to a widespread domestic demand for better environmental protection. ${ }^{179}$ The law on ESIA in Cameroon falls short of effective implementation as is evidenced through the numerous environmental and social conflicts arising from projects implemented across the country. It is therefore crucial that the implementation of ESIA should be improved in order to enhance soil protection and the environment in general.

Other impediments to an effective ESIA process include inadequate baseline data, procedural flaws in scoping, exorbitant administrative fees, absence of an appeal procedure, incompetent personnel and over-centralisation of EIA powers. ${ }^{180}$ Furthermore, one of the inherent weaknesses of the ESIA law in relation to soil protection is that small-scale agriculture is passing through the sieve of the law on ESIA with serious soil impacts. Although this type of agriculture is usually practised on small scales, the total land surface areas of these activities when summed up for all the farmers is enormous and can produce serious ecological or soil degradation. Small-scale farmers have little or no motivation or incentive to adopt sustainable soil management measures or practices as their immediate concern is feeding their families. ${ }^{181}$ It has been estimated that the agricultural sector in general employs more than $70 \%$ of Cameroonians. ${ }^{182}$ This is enough reason for the inclusion of small-scale agriculture among the categories of agricultural projects which are subject to ESIA. For the purpose of soil protection, all agricultural projects, whether practised on a small or large-scale, need or ought to comply with the law on ESIA. Theoretically, this may make sense, but the critical question is: who should pay for the cost of ESIA given that small-scale farmers cannot afford to pay for such assessment? This is probably what can render such a prescription a non-starter. Another salient question is: who should control the ESIA, given that small-scale farms amount to millions of them, scattered all over the country? One way of resolving this is to provide extension services at local levels to sensitise local famers on the importance of practising sustainable farming and to monitor and control their activities.

\subsubsection{Provisions of public participation and access to environmental information}

Public participation is a key principle of international environmental and sustainable development law, ${ }^{183}$ which was enshrined in the 1992 Rio Declaration with reference to three interrelated pillars consisting of 1) the right to participate in environmental

179 Dashaco \& Tarh (2018: 196).

180 Alemagi et al. (2007).

181 See Ginzky et al. (2019: 4).

182 Tchoffo (2009: 3).

183 It is reflected in the Rio Declaration 1992; the Non-Legally Binding Instrument on All Types of Forests; the Convention on Biological Diversity, among others. 
decision-making, 2) the right for citizens affected by environmental decisions to receive pertinent information, and 3) the right to access judicial and administrative proceedings, including redress or remedy, to enforce these rights. ${ }^{184}$ These may loosely be referred to as Environmental Democracy (ED) rights. ${ }^{185}$ Public participation has become an indispensable approach to creating a sense of ownership among participating stakeholders, and ultimately to facilitate law enforcement. ${ }^{186}$ In line with international guidance, access to environmental information and public participation in Cameroon is guaranteed by the 1996 Framework Law on Environmental Management, ${ }^{187}$ the 1994 Forestry Law, ${ }^{188}$ and the 2013 ESIA Decree, which also makes public consultation and hearings mandatory during ESIA processes. In fact, consultation with the public is a key feature of EISA procedures. ${ }^{189}$ Consultation ensures public participation in decision-making and thereby strengthens the quality of decisions. ${ }^{190}$ The Preamble of Cameroon's Constitution similarly provides for public participation in environmental matters by mandating that it is the duty of all citizens to work for the protection of the environment. Information, decision-making and participation are supposed to involve all concerned stakeholders, but, sadly, sometimes there are no consultations when granting concessions over lands. ${ }^{191}$ Given that freedom of information laws exists in Cameroon, the government should provide the necessary institutional support for implementation. ${ }^{192}$

Access to information is indispensable for effective public participation in decisionmaking, which is vital for conservation. ${ }^{193}$ Access to information is guaranteed under the Convention on Access to Information, Public Participation in Decision-Making and Access to Justice in Environmental Matters (Aarhus Convention) ${ }^{194}$ and in the International Convention on Civil and Political Rights. ${ }^{195}$ Under Principle 10 of the 1992 Rio Declaration, access to environmental information is seen as vital to environmental and natural resource management. National legislation would therefore do well to ensure that responsibility for providing information to concerned stakeholders is clearly required from public authorities and all actors who are charged with

184 Report of the UN Conference on Environment and Development: Annex 1. Rio Declaration on Environment and Development, UN Doc A/CONF.151/26 (Vol.I), 12 August 1992, Principle 10 .

185 See Ngwome (2018: 257).

186 See Costenbader (2009: 36).

187 See generally Articles 6, 7, 9, 72, 73 and 74.

188 See Articles 51(2), 61 and 142(3).

189 See Ngwome (2018: 130).

190 Ibid.: 131.

191 Tamasang \& Ngwome (2018: 951).

192 Ibid.

193 See Ngwome (2018: 297).

194 Adopted on 25 June 1998.

195 Adopted on 16 December 1966. See Article 14 on access to justice. 
implementing policies, as well as from economic operators (investors). ${ }^{196}$ Information needs to be provided in an effective manner, that is it should be given in forms that are accessible to a variety of actors and allow enough time for consultations. ${ }^{197}$ Public access to information is also required so that civil society can effectively carry out its watchdog function in all sectors prone to soil degradation. Access to information is linked with the right of access to justice in environmental matters. ${ }^{198}$ The government is required to provide the public with information about the rights they possess and the judicial resources available to protect them.

With regard to sustainable soil management, public participation and access to information is not sufficiently implemented in Cameroon. Information on soil is often inadequate, out-dated, not available in digital format, and not referenced geographically. The danger of soil degradation in the country is little known to the general public or it is underestimated by those who are informed and therefore does not constitute an immediate concern. Information on the status of soil and appropriate measures to achieve sustainable soil management are critical. Adequate information on sustainable soil management is crucial and should be integrated into curricula at all levels of education.

The 1996 Framework Law on Environmental Management prescribes public participation and access to environmental information in Articles 9,73 and 74, which call for the participation of populations in environmental management, especially through consultation mechanisms to take stock of the opinion and contributions of the populations; free access to environmental information; sensitisation, training, research and education on the environment at all levels, using the media and other means of information; representation of the populations within environmental advisory bodies; and production of environmental information.

Although commendable, the 1996 legislative prescriptions are not exhaustive and require further insights into the understanding and then application of the law by way of an enabling instrument. Again, such an instrument has not been crafted and so this renders the application of these provisions difficult.

There is relevant case law of the African Commission on Human and Peoples' Rights (the African Commission) establishing a procedural aspect of Article 24 of the African Charter on Human and Peoples' Rights (ACHPR) dealing with the obligation to consult and obtain free and prior informed consent - the principles of environmental democracy. In fact, the African Commission has dealt with this on many occasions in the context of land-grabbing, recognising indigenous peoples' rights over ancestral or traditionally owned land. In Centre for Minority Rights Development \& Minority Rights Group International (MRG) on behalf of the Endorois Community $v$ The

196 See Costenbader (2009: 49).

197 Nhantumbo \& Marisa (2015: 70).

198 Ngwome (2018: 296). 
Republic of Kenya ${ }^{199}$ the Endorois indigenous community in Kenya successfully contested, among other rights, the violation of their land and natural resource rights, and, above all, their expulsion from their ancestral land by the Kenyan Government under the ACHPR, the Constitution of Kenya and international law. In a landmark decision approved by the African Union on 2 February 2010, the African Commission found and ruled that the Kenyan Government had violated the Endorois' rights to religious practice, to property, to culture, to the free disposition of natural resources, and to development, under the ACHPR (Articles 8, 14, 17, 21 and 22, respectively). The Commission declared the eviction of Endorois from their ancestral lands illegal. The summary, the enforcement of the decision, and the significance of the case are stated by the Centre for Minority Rights Development Kenya on their website. ${ }^{200}$

In Social and Economic Rights Action Centre (SERAC) v Nigeria (Ogoni case) (2001), SERAC's communication contained, among others, the forced mass eviction of residents of the Maroko community of Lagos State and failure to provide alternative housing in violation of their rights to housing and property, alleging violations of $\mathrm{Ar}$ ticles 2, 4, 5, 6, 7, 14, 15, 16, 17, 18, 22, and 24 of the ACHPR and Article 16 of the Protocol to the ACHPR on the Rights of Women in Africa in addition to violations of corresponding provisions of the Universal Declaration of Human Rights (UDHR), the International Covenant on Economic, Social and Cultural Rights (ICESCR), the International Convention on the Rights of the Child, and the International Covenant on Civil and Political Rights (ICCPR). ${ }^{201}$ The African Commission, in its ruling in 2001, found the Federal Republic of Nigeria in violation of Articles 2, 4, 14, 16, 18(1), 21 and 24 of the ACHPR and appealed to the government to ensure the protection of the environment, health and livelihood of the people of Ogoni land by stopping all attacks on Ongoni communities and leaders and permitting citizens free access to the territory; undertaking a comprehensive clean-up of lands and rivers damaged by oil operations; ensuring that appropriate ESIAs were prepared for any future oil development; and that the safe operation of any further oil development was guaranteed through effective and independent oversight bodies for the petroleum industry; and providing information on health and environmental risks and meaningful access to regulatory and decision-making bodies to communities likely to be affected by oil operations, etc.

199 See 276/2003 - Centre for Minority Rights Development (Kenya) and Minority Rights Group International on behalf of Endorois Welfare Council v Kenya, at https://www.hrw.org/sites/default/files/related_material/2010_africa_commission_ruling_0.pdf, accessed 17 October 2019.

200 See the website of the Centre for Minority Rights Development (Kenya) at https://www.escrnet.org/caselaw/2010/centre-minority-rights-development-kenya-and-minority-rights-groupinternational-behalf, accessed on 17 October 2019.

201 See the Secretary African Commission on Human and Peoples' Rights, Banjul, Communication, Social and Economic Rights Action Center v Nigeria, at http://www.hlrn.org/img/documents/SERAC\%20v\%20\%20Nigeria\%20Communication.pdf, accessed 17 October 2019. 


\subsubsection{Right to appeal administrative decisions - access to courts}

The right to appeal administrative decisions or the right of access to justice is crucial for sustainable environmental and natural resource management and, therefore, soil protection. Environmental and natural resource management, including land and soil, usually create conflicts between the various actors involved. Adequate access to justice is a critical component of effective environmental, natural resources and especially land and soil management, without which stakeholders will be unable to enforce and protect their rights, rendering natural resources governance ineffective. In fact, the ability to enforce rights is one of the critical pillars of any governance system. Poor dispute settlement mechanisms can undermine efforts to ensure accountability, which may weaken the chance of effective participation, especially for vulnerable groups. Generally, environmental justice is not well institutionalised in Cameroon and, therefore, less developed. In fact, an environmental law court in Cameroon is absent. Judges and other court officials are not well-informed about the importance of soil protection. There is therefore the need for strong, independent dispute resolution mechanisms with the capacity to identify and deal with grievances.

Access to courts or justice answers the following concerns: Is there a system for identifying, preventing and resolving conflict between stakeholders such as litigation, alternative dispute resolution, or administrative review? Has awareness of the system's existence been raised? Is it cheap and accessible? Does it provide timely results? ${ }^{202}$ Access to courts forms an integral part of a country's governance system and can be understood as the availability of recourses that citizens can make use of in the event of violations of their substantive and procedural rights. ${ }^{203}$ Avenues, such as administrative procedures, judicial forums, traditional authorities, and arbitration guaranteed under relevant environmental, natural resources and related laws, ${ }^{204}$ are all available for settling disputes. These avenues, however, need to be strengthened in order to guarantee sustainable soil protection. There is therefore the need to organise workshops or other platforms to help develop the requisite capacity among court officials and judges. Under international law, ${ }^{205}$ governments have a number of duties and obligations to

202 See Costenbader (2009: 112); Chapman et al. (2014: 28).

203 Ngwome (2018: 318).

204 The 1996 Framework Law on Environmental Management; the 1994 Forestry Law; the 1998 Water Law; the 2003 Biosafety Law; and the 1974 Land Tenure law.

205 Reference to the right of access to justice under international law includes: Principle 10 of the Rio Declaration on Environment and Development; Articles 2, 9, 14, 26 and 50 of the International Convention on Civil and Political Rights and its First Protocol; Articles 8, 11, 13, 20, 28, 32 and 40 of the UN Declaration on the Rights of Indigenous Peoples; Article 15 of the Convention for the Elimination of All Forms of Discrimination Against Women; Articles 9,12 and 14 of the ILO Convention No. 169; Articles 7, 8 and 10 of the Universal Declaration of Human Rights; Article XVI of the 2003 African Convention on the Conservation of Nature and Natural Resources. 
ensure adequate access to the essential components of justice. These are access to effective judicial proceedings, and freedom from economic obstacles preventing citizens from accessing the courts, which include free legal services and the strengthening of community support programmes to ensure that marginalised groups that would generally be excluded from accessing the courts, owing to lack of technical or financial means, are able to benefit from the protection of judicial bodies. ${ }^{206}$

Access to an appropriate mechanism for settling disputes is crucial for enforcing rights to participate, access to information, etc. Access to justice also increases the accountability of authorities and project implementers and protects the rights of affected stakeholders as it provides an opportunity to challenge acts and omissions by public authorities and project developers. ${ }^{207}$ Dispute settlement mechanisms need to be equitable, transparent, accountable and independent. The government is required to provide the public with information about the rights they possess and the judicial resources available to protect them, such as the right to a fair trial, which includes the right to legal assistance; the right of defence; and the right to reasonable time for the preparation and formalisation of arguments; the right to an effective remedy, which should be "simple, urgent and accessible". ${ }^{208}$ Because it can be difficult for vulnerable groups, such as local communities, to enforce their rights, owing to lack of education and capacity, increasing community-level legal awareness is crucial in helping them to demand their rights. ${ }^{209}$ Measures that can be taken by government to ensure that the legal frameworks support and enable access to justice regarding soil protection and beyond have been suggested, among others, to include the existence of clear rules to enable citizens as well as communities to initiate litigation or be parties to a dispute (i.e. legal standing); ensuring that the recognition of the right to judicial review of administrative actions is enshrined in the Constitution; developing programmes to raise awareness among the population of their right to access courts and of any initiatives that can facilitate this access; providing legal aid, i.e. legal support and services for vulnerable and marginalised persons, which could include measures to reduce the costs of accessing the judicial system or the provision of judicial proceedings in local languages; and ensuring that tribunals do not have any substantial interest in the outcome of the matter they are presiding over. ${ }^{210}$

Procedural rights such as full and effective public participation, access to information and access to justice are key to ensuring and enhancing sustainable soil management and protection. 
3.3.5.4 Specific instruments to control the behaviour of foreign investors

\subsection{Compliance with public law}

Every administration must make sure that any investor who is interested in its domain of competence should meet the provisions of the regulation in force in that sector. In effect, the institutional dispositions of Cameroon give latitude to every public administration to control and monitor all investments/investors operating within their respective areas of competence. For instance, the administration in charge of hydrocarbons ensures the respect of the regulation in force in that sector such that every investor must conform to the provisions of the petroleum code. This is the same in the case of soil and subsoil wherein the administration in charge of water makes sure that investors in this domain respect the provisions of the water regulation in force. The administration in charge of mines ensures that investors comply with the provisions of the regulation in force in this sector. This is the same principle applicable in the domains of forestry and environmental protection.

Despite the power given to each administration to ensure the respect of the regulations of the different sectors by investors, it is also common to see clandestine operators who do not conform to these texts in the respective sectors. This is why there are mining exploiters who do not carry out their activities in conformity with the regulation in force in that sector. This situation may be explained through the lack of mastery of the mining cartography as well as the deplorable attitudes of some administrative and traditional authorities. These are some of the situations that cause degradation of soils and environment because once these clandestine operators exploit a given site, they simply abandon it without reinstating or rehabilitating the site in question.

Finally, Cameroon has a law that encourages private investment. The law in question is Law No. 2017/015 of 12 July 2017 to modify and complete some of the provisions of Law No. 2013/004 of 18 April 2013 on the encouragement of private investment in the Republic of Cameroon. This law treats all foreign investors equally without considering their respective countries of origin. Within the prism of this law, there is a unique organ ${ }^{211}$ put in place to provide information to any investor with respect to his type of activity. The investor may comply with all the necessary formalities for the creation of an enterprise without having to go from one administration to another.

211 The Cameroon National Investment Corporation. 


\subsection{No unfair or illegal land acquisition}

Access to land for foreign investors is governed by texts that we have already cited sufficiently above - Ordinance No. 47/01 of 6 July 1974 to establish the land tenure regime. Article 10 provides that:

(1) natural persons and corporate bodies of foreign nationality or incorporated bodies wishing to invest in Cameroon may conclude lease agreements or purchase landed property except in the border areas.

(2) deeds drawn up for this purpose must bear the prior approval of the minister in charge of lands or bear the penalty of being declared null and void. As concerns diplomatic and consular missions as well as international organisations, the visa of the minister of external relations and the minister in charge of lands is required.

(3) the state, in the event of a resale, has a pre-emptive right of purchase over the property, taking account of the initial price, developments carried out and amortisation.

The Mining Code similarly provides in Article 106 that upon the signing of the mining agreement, the state will, after consultation with the affected populations, grant to the mining operator the lands necessary for the mining of the discovered mineral substances, in accordance with the laws and regulations in force.

\subsection{Fair taxation}

Looking at Law No. 2018/012 of 11 July 2018 relating to the financial regime of the state and other public entities, the domain of taxation is regulated by a single administration in Cameroon, being the ministry in charge of finance. In effect, even though it is provided in many legal texts, the financial provisions of these texts are formulated by the ministry in charge of finance, otherwise all the other ministries will have to seek the opinion of the said ministry regarding the financial provisions to be inserted in any legal document. However, at the start of every budgetary exercise, the ministry in charge of finances elaborates upon and prepares the adoption of a finance law. This law is applied by means of a circular providing instructions for the execution of the finance law, the follow-up and control of the budget of the state, public administrative establishments, territorially decentralised entities, and the other organs under subvention. It is these two texts that determine the financial gains expected in the public treasury and in all sectors of activity.

\subsection{Relevant ministries and state institutions and their responsibilities}

The relevance of discussing ministries and state institutions lies in the fact that they are responsible for the implementation of the law and their absence from this report will definitely paint an incomplete picture. The laws have their gaps, so too do the 
institutions. Even when laws appear to be complete, it has been established in this report that institutions are critically important for the effective implementation of the law.

\subsubsection{Ministry of Agriculture and Rural Development}

According to Decree No. 2005/118 of 15 April 2005, the Ministry of Agriculture and Rural Development (MINADER) is in charge of elaborating, implementing and evaluating government policies in the domains of agriculture and rural development. The ministry also has the mandate of developing standards and rules applicable to agriculture. It is the responsibility of the ministry to identify and prepare projects and programmes for investments in the agricultural sector. Since agriculture is associated with soil degradation, the role of this ministerial department is critical for soil protection.

\subsubsection{Ministry of State Property, Surveys and Land Tenure}

According to Article 1 of Decree No. 2012/390 of 18 September 2012, the Ministry of State Property, Surveys and Land Tenure (MINDCAF) is responsible for elaborating and implementing government policy related to land tenure, land registration and land surveying. This includes the elaboration of legislative and regulatory texts in its different areas of competence; management of government's private and public property; making proposals for the attribution of state lands; and elaboration and conservation of cadastral plans. Since soil degradation-related activities such as mining and agricultural projects begin with the acquisition of land, the role of this ministerial department is crucial for soil protection.

\subsubsection{Ministry of Environment, Protection of Nature and Sustainable Development}

According to Decree No. 2012/431 of 1 October 2012, the Ministry of Environment, Protection of Nature and Sustainable Development (MINEPDED) has as principal missions: the definition of modalities and principles for the sustainable management of natural resources; the definition of environmental management measures in collaboration with other ministries and concerned specialised institutions; the elaboration of sectoral master plans for the protection of the environment in liaison with other interested ministries; coordination and monitoring of all interventions by regional and international organisations in the areas of environmental and natural resources in liaison with the Ministry of External Relations and concerned administrative bodies; 
monitoring of environmental compliance in the implementation of large projects; information and sensitisation of the public to encourage their participation in the management, protection and restoration of the environment and nature; negotiation and implementation of international conventions and treaties related to the protection of environment and nature in liaison with the Ministry of External Relations. Since soil degradation is a subset of environmental degradation, MINEPDED ensures that ESIA, strategic environmental evaluation and other actions are properly conducted. MINEPDED is the overseer ministerial department for monitoring the respect of environmental and social commitments and meting out of administrative sanctions to project implementers violating environmental standards.

\subsubsection{Ministry of Forests and Wildlife}

The Ministry of Forests and Wildlife (MINFOF) is responsible for elaborating and implementing national policies in matters of forestry and wildlife and is thus charged with the management of protected areas and conservation concessions in the national domain. ${ }^{212}$ MINFOF also undertakes regeneration, reforestation, forest inventories, monitoring and application of logging standards, which makes this ministry a crucial stakeholders in issues of soil protection, as sustainable and unsustainable forest management has implications for soil protection and soil degradation, respectively.

\subsubsection{Ministry of Economy, Planning and Regional Development}

According to Article 1(2) of Decree No 2008/220 of 4 July 2008 relating to the organisation and functioning of the Ministry of Economy, Planning and Regional Development (MINEPAT), the ministry is in charge of developing, monitoring and coordinating government's economic policy; elaborating norms and rules of regional planning, and controlling their application. Poor land-use planning is a driver of soil degradation. MINEPAT's role is therefore relevant for general environmental protection and soil protection, in particular, in the context of establishing and running investments and economic activities likely to contribute to soil degradation.

212 See Decree No. 2005/099 of 6 April 2005 to organise the Ministry of Forest and Wildlife. See also Republic of Cameroon (2012: 48). 


\subsubsection{Ministry of Urban Development and Housing}

Created by Presidential Decree No. 2004/320 of 8 December 2004, the Ministry of Urban Development and Housing (MINDUH) works in collaboration with decentralised territorial entities (urban and rural councils) in redressing urban challenges in order to build well-planned and convenient cities. It is the supervisory ministry to its sub-organisation, the Cameroon Real Estate Company (Société Immobilière du Cameroun). MINDUH and its subordinate bodies are the backbone of urban policy in Cameroon. According to Decree No. 2005/190 of 3 June 2005, MINDUH is in charge of, among others, the elaborating, implementation and evaluation of government policy on urban development and housing; planning and control of the development of cities; development and monitoring of the implementation of urban development strategies and restructuring; definition and monitoring compliance of standards for sanitation and drainage; the beautification of urban centres; and the implementation of the social housing policy. The role of MINDUH is therefore crucial in ensuring that urban development projects do not lead to soil degradation.

\subsubsection{Ministry of Trade}

By Decree No. 2011/408 of 9 December 2011 on the organisation of the government, the Ministry of Trade is responsible for the development and implementation of government policy in the field of trade. With respect to soil degradation or protection, this ministry is responsible for the promotion and defence of a quality label for products for the local market; monitoring the application of import standards, in liaison with the administrations concerned; monitoring the conservation and distribution circuits of consumer products; monitoring the development and application of the standards of measuring and quality control instruments in conjunction with the administrations concerned; monitoring the development or approval of standards for the presentation, storage and distribution of consumer products and compliance with these standards by economic operators in relation with the administrations concerned; application of administrative sanctions in the event of fraud or non-compliance with the standards set; etc. The role of the Ministry of Trade is therefore relevant for preventing the importation and transportation of products likely to affect the quality of the soils.

\subsubsection{Ministry of Mines, Industry and Technological Development}

The Ministry of Mines, Industry and Technological Development (MINMIDT) is in charge of the elaboration and implementation of mining and industrial policy and the development of strategies for technological development in the different sectors of the 
national economy. The activities promoted by this ministry are drivers of soil degradation. The role of MINMIDT is therefore crucial in the context of this discussion and should be given due consideration.

\subsubsection{Ministry of Scientific Research and Innovation}

The Ministry of Scientific Research and Innovation (MINRESI) is responsible for the elaboration and implementation of national policies in matters of scientific research and innovation and is thus charged, among others, with coordination and control of scientific research activities in collaboration with all sectoral ministerial departments and organisations. ${ }^{213}$ Since scientific research has implications for soil protection or degradation, MINRESI's role is also crucial in the context of this assessment and should be strengthened.

\subsubsection{Ministry of Livestock, Fisheries and Animal Industries}

The relevance of the Ministry of Livestock, Fisheries and Animal Industries (MINEPIA) is in implementing policies aimed at reducing soil degradation caused by animal husbandry practices.

\subsubsection{Institute of Research for Agricultural Development}

The mandate of the Institute of Research for Agricultural Development (IRAD) ${ }^{214}$ is to elaborate and implement high-level scientific research based on the country's key priority axes and needs, taking into consideration agricultural development in the country's five agro-ecological zones. IRAD also ensures the sustainable management of natural resources and conservation of the environment. It therefore plays a relevant role in ensuring that agricultural development does not lead to soil degradation in the country.

213 Republic of Cameroon (2012: 48).

214 IRAD was created by Presidential Decree No. 96/050 of 12 March 1996 as modified by Decree No. 2002/230 of 6 September 2002. 


\subsubsection{Inter-Ministerial Committee for the Environment}

Hosted by MINEPDED, the Inter-Ministerial Committee for the Environment consists of 14 key ministerial departments and is responsible for assisting the government in its mission of elaborating, coordinating, executing and controlling environmental policies. Since soil is an integral part of the environment, this committee's role is crucial in guarding against negative soil impacts of sectoral policies and projects.

\subsubsection{National Consultative Commission for the Environment and Sustainable Development}

The National Consultative Commission for the Environment and Sustainable Development was created by the environmental framework law with the mission of ensuring a wide participation of all stakeholders ${ }^{215}$ in the development and implementation of environmental management policies and strategies. In line with its mission, this commission's role is also critical for soil protection.

\subsubsection{Regional and local authorities}

Regarding the implementation of the existing environmental provisions relevant to soil protection, the regional and local authorities in Cameroon - within the framework of the missions devolved upon them by central government - ensure, through monitoring and inspection, that all activities carried out by individuals and enterprises do not cause environmental damage. They exercise this role concurrently with the relevant central administrative departments, under terms and conditions provided for by law.

\subsubsection{National Council for Planning and Sustainable Development of the Territory}

The National Council for Planning and Sustainable Development of the Territory is one of the institutions provided for by Law No. 2011/008 of 6 May 2011 laying down guidelines for the planning and sustainable development of the territory of Cameroon. ${ }^{216}$ When this is set up, it will be responsible for issuing opinions and suggestions on the orientations and the conditions of implementation of the policy on planning and

215 Such stakeholders include NGOs, associations, the private sector, professional associations, common initiatives groups.

216 See Article 27. 
sustainable development of the territory by the state and the decentralised territorial authorities. It also issues opinions, at the request of the government, on major draft laws or regulations relating to spatial planning and sustainable development. In line with its functions, this council's role is equally critical for soil protection.

Generally, the institutional framework lends indirect and minimal support to the protection of soils. The relevant ministries also exercise their functions through regional, divisional and subdivisional delegations. In the framework of the implementation of decentralisation, the relevant ministries are by law required to transfers part of their competencies and resources to decentralised entities for proper regional and local-level development.

\subsection{Conclusion}

The assessment of Cameroon's environmental and related natural resources policy and legal instruments reveals that there is no comprehensive and coherent soil policy or soil legislation which can inform sectoral laws and legislation incentivising soil degradation in Cameroon. However, the existing environmental and related natural resources laws and policy instruments contain provisions which are relevant to soil protection to an extent. Soil protection-relevant provisions are therefore fragmented and scattered across national legislations which are most often poorly implemented. Consequently, soil protection-related provisions are not effectively implemented and enforced in Cameroon. Soil as a natural resource is thus not sufficiently integrated and protected under the Cameroonian law. The analysis also shows that sustainable soil management is not an immediate concern in Cameroon, especially as it has not been directly addressed by a specific legal instrument and also because the majority of sectoral legal and policy instruments driving soil degradation do not directly refer to the need to protect soils. Furthermore, the institutional framework which is responsible for the effective implementation of the scattered legislative provisions on soil protection operates, in most cases, in isolation. Consequently, there is a veritable problem of collaboration, cooperation and coordination of actions that could improve the health of soils.

While some soils in Cameroon are naturally of poor quality, with natural factors accounting for their degradation, such as climatic factors, the degradation of some of the soils is attributed to human or anthropogenic drivers, incentivised by sectoral legislation. Thus, soil degradation in Cameroon is linked to a combination of drivers. This chapter considers all drivers of soil degradation in Cameroon, but from a legal 
perspective. Legislation on the main drivers of soil degradation in Cameroon are those dealing with agriculture; mining; industrial development; demographic growth, urban sprawl and land planning regulatory framework; climate change; land tenure insecurity; wildfires in farming, hunting, and cattle rearing. Legislation and policies governing these sectors drive or incentivise soil degradation, but also contain relevant provisions for soil protection, demonstrating the strengths and weaknesses of such legislation in terms of soil protection.

\subsection{Agriculture}

Most agricultural projects are associated with soil degradation, caused either by the misuse of chemical products (pesticides and fertilizers) or unsustainable farming methods such as the slash-and-burn method and bushfire practised by most local communities across the country and the ankara system practised in the Western Highlands of Cameroon.

\subsubsection{Relevant legal provisions}

The matter of soil degradation may be scantly referred to in some legal texts, whereas these texts are expected to protect the soil. Problems arise when it comes to the implementation of these texts. The relevant legal texts and provisions include:

\subsubsection{Law No. 2003/003 of 21 April 2003 on phytosanitary protection}

This law which lays down the principles and rules governing phytosanitary protection specifically relates to matters of agriculture. Section 21(1) provides that only phytosanitary products that have been homologated or wholesales which have been temporarily authorised may be imported, distributed, packaged or used in Cameroon. Also of relevance is Section 19(1) which provides that chemical treatments must be performed in compliance with good agricultural practices with a view to preserving the health of humans and animals and protecting the environment from the hazards caused by the presence or the accumulation of residue of phytosanitary products. Section 2 is also relevant in the context of this discussion. It sets out the various measures to be undertaken by the administration in charge of agriculture to achieve phytosanitary protection such as the setting, adoption and adaptation of norms in the domain; the prevention and control of plant and plant product pests; the use of sanitary products which are safe for humans, animals and the environment; the dissemination and publication of appropriate phytosanitary protection techniques; the control of importation and 
exportation of phytosanitary products, plants and plant products and other regulated items that may lead to the release of plant pests, and the control, throughout the national territory of phytosanitary products, plants and plant products that may serve as vectors of harmful organisms. Under Sections 5 and 6, the administration in charge of agriculture may request support from relevant ministries and other services in the context of the implementation of phytosanitary legislation and, in this respect, may delegate its powers regarding phytosanitary protection to any natural person or corporate body under the conditions fixed by law.

The implementation of the 2003 law on phytosanitary protection is enabled by a series of decrees. ${ }^{217}$ One of the enabling texts or complementary decrees to the law is Decree No. 2005/0770/PM of 6 April 2005 establishing the terms and conditions of the fight against phytosanitary products with the following relevant provisions. Article 9 states that the fight against harmful organisms should be done with respect to the principle of integrated protection with the aim of reducing the reliance on and exercising effective control over the use of phytosanitary products, and to minimise the risks involved with the abusive and inappropriate use of phytosanitary products. Article 10 calls for the implementation of an integrated approach to fight against the use of phytosanitary products as a priority involving the participation of farmers through the provision of assistance and resources necessary to promote initiatives that aim at the adoption and implementation of the integrated fight; support of research activities that involve farmers; support of the organisation of training programmes that bring together farmers, researchers and those who spread the information; sensitisation of consumers on the quality of agricultural products; and training of farmers on the techniques of integrated protection.

In effect, the failure to implement, or poor implementation of these texts may contribute to soil degradation. This is the case with the law on phytosanitary protection, ${ }^{218}$ and the sectorial law in the domain of agriculture which is aimed at protection of vegetation and its attendant products through the use of phytosanitary products. The stakeholders in the implementation of this law, that is farmers and economic operators (in phytosanitary products), do not always comply with the regulation in force in this domain. The commercialisation and use of phytosanitary products that are not homologated contributes to soil degradation. The control of phytosanitary products used in the national territory appears to be less efficient because the borders are porous. This situation enables the traffic of all sorts of dangerous phytosanitary products.

The law in this domain aims at effectively regulating phytosanitary products, but still falls short of effective implementation and monitoring. Thus, from a phytosanitary

217 See Decree No. 2005/0771/PM of 06 April 2005 on modalities for plant quarantine operations; Decree No. 2005/0772/PM of 06 April 2005 on the control and registration of phytosanitary products; Decree No. 2005/0770/PM of 06 April 2005 on modalities for phytosanitary control operations; Decree No. 2005/0769/PM of 06 April 2005 Creation of a Phytosanitary Council.

218 Law No. 2003/003 of 21 April 2003 on plant protection. 
perspective, the law seems to have covered all the activities that use phytosanitary products, which we have reason to commend, but we must also remark that implementation has remained a problem. In the first place, farmers do not respect existing prescriptions on the use of phytosanitary products because of inadequate monitoring. In the second place, inadequate cooperation or communication between sister administrations renders implementation difficult. Thus, there is an absence of a coordinated approach to sustainable land management as many different ministerial departments are involved with the management of environmental pollution such as causes soil degradation, with poor collaboration. There is therefore a need for government to urge users of phytosanitary products to comply with the relevant regulations, and government institutions responsible for law implementation and enforcement to implement and enforce the relevant regulations in close collaboration.

4.1.1.2 Law No. 2003/007 of 10 July 2003 governing the activities of the fertilizer subsector

This law aims to "increase the productivity of farms and increase agricultural production and the sustainable management of natural resources" in Cameroon through the regulation of the following activities: the production, import, export, packaging, distribution and use of fertilizers. ${ }^{219}$ Although this law seeks to avoid the harmful effects of fertilizers, it falls short of halting soil degradation in that the production, import, export, packaging, distribution and use of fertilizers do not always conform to its provisions in Cameroon. Unfortunately, the enabling instrument of this law has not been enacted, making its implementation difficult. This also makes the monitoring and control of fertilizers in the country difficult and opened to corrupt practices. One can find fertilizers that are not homologated being used by farmers. This smacks of illegal practices in the sector regarding the use of these fertilizers. There is therefore a need for the government to urge users of fertilizers to comply with the relevant regulations and government institutions responsible for law implementation and enforcement to implement and enforce the relevant regulations.

\subsubsection{Decree No. 2011/2584/PM of 23 August 2011 laying down soil and sub- soil protection modalities}

Most agricultural projects are associated with soil degradation caused either by the misuse of chemical products (pesticides and fertilizers) or by unsustainable farming methods such as slash-and-burn, bushfire or ankara methods practised by most local

219 See Article 1. 
communities across the country. Decree No. 2011/2584/PM of 23 August 2011, which lays down the soil and subsoil protection modalities, regulates activities related to land use, in order to avoid erosion, desertification, and the loss of arable land. It requires any natural or legal person, public or private, who uses fertilizers and/or pesticides to ensure that these products correspond in quality and quantity to the standards set by national and international legislation. On the one hand, the decree prescribes a preliminary evaluation of the physical and chemical state of the soil and, on the other, a regular evaluation of the impact of these products on the environment. The provisions of this decree are not properly respected by most local farmers who by the misuse of chemical products (pesticides and fertilizers) or unsustainable farming methods, cause soil degradation. In fact, slash-and-burn, bushfire and the ankara agricultural practices are detrimental for soils. Consequently, there is the need for policy measures to ensure that the provisions of the decree are complied with by small-scale farmers. This can be done by developing policies that are geared toward the sensitisation of farmers on the danger of using non-homologated chemicals and pesticides and other unsustainable farming practices.

\subsubsection{Common Provisions on the Homologation of Pesticides in the Economic and Monetary Community of Central Africa Zone}

The use of pesticides in Cameroon is governed by a community regulation, namely the Common Provisions on the Homologation of Pesticides in the Economic and Monetary Community of Central Africa (CEMAC) Zone. The aim of this text can be found in its Article 1, which is:

to bring together experiences and expertise of the member States for the evaluation and homologation of pesticides in order to ensure their rational and judicious use, as well as the protection of human health and the environment.

The scope of application of this regulation can be found in Article 3(1) which includes the:

experimenting, authorization, importation, exportation, transportation, transit, stocking, marketing, use, control and elimination of active materials and formulated products of pesticides within the States of the CEMAC zone, within the directives adopted by the FAO.

Unfortunately, this community regulation is not always complied with owing to many insufficiencies and difficulties encountered on the ground. In effect, the loose nature of the borders of the CEMAC countries facilitates the entry of contraband pesticides into states. Such products do not pass through the Homologation Committee and, as such, neither the quality nor the efficiency of these products can be asserted. These products find their way into the hands of farmers, notably the local farmers who use them either through ignorance or because of their hugely affordable costs. The second difficulty in the application of this community regulation has to do with the importation 
of unauthorised products by certain delinquent traders. Chemical products that are toxic to the soil also find their way into the hands of citizens who use them in ignorance or because of their affordable prices. There is therefore a need for the secretariat of CEMAC to urge member states, for instance Cameroon, to comply with and enforce the regulation.

Regarding the legal status of CEMAC regulations and their relationship to national law, it should be noted that in the contemporary world, countries with common boundaries are coming together through regional cooperation and integration to respond to the exigencies of globalisation. In this regard, a supranational structure, the Economic and Monetary Community of Central Africa - known by its French acronym as CEMAC - to replace the Economic and Customs Union of Central Africa was established in 1994. CEMAC aims to promote subregional integration within the framework of economic and monetary union through common political, financial, legal and economic structures and policies. Because of these, community laws have been encouraged and, at times, imposed. The gradual application of CEMAC community laws has led to sovereignty decline of member states. Since CEMAC member states apply legal monism, the treaty instituting CEMAC as superior to all national laws. This implies the subordination of the national law-making bodies to the community. Thus, after the Constitution, CEMAC laws are at the apex of the pyramid of laws in Cameroon as per Article 45 of the Cameroonian Constitution. Thus, by opting for the monist approach in meeting its international commitments, which asserts the supremacy of international law over national law, this constitutional provision implies a direct reception of the CEMAC community laws by member states. The CEMAC treaty goes further, stating that the community regulations are directly applicable. They, therefore, have a supraconstitutional value. By implication, the CEMAC treaty and regulations override any national laws. The superiority of CEMAC laws is guaranteed by the possibility of sanctioning their violation as per Articles 14 and 17 of the additives to the CEMAC treaty. Thus, this implies that the member states are bound to observe them.

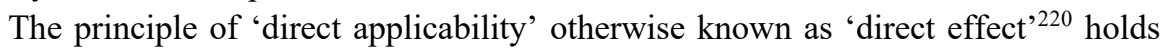
that CEMAC regulations are directly applicable as they are mainstreamed into the national legal order without the need of any national measures of transposition or reception. Community laws therefore create rights and obligations for individuals, which national authorities must uphold. The basis of direct applicability is the specificity of the community legal order; it is in the objective of integration that this principle is applied. The CEMAC treaty is silent regarding the principle of 'primacy' according to which, in case of any conflicting or contradictory provisions or incompatibility between community law and national law, the former prevails. However, this issue is settled by Article 45 of the Cameroonian Constitution and therefore by the direct

220 Article 21 of the Additive to the CEMAC treaty. This principle has as its basis the integration of the community legal order. 
application of the community regulation on the common provisions on the homologation of pesticides with relevance to soil protection.

Now that the Constitution enables the direct application of this piece of legislation and, of course, its supremacy over national laws, this enhances the available legal arsenal for the protection of soils in Cameroon. It is therefore incumbent on the concerned administrations to ensure its effective implementation to achieve best results in terms of soil protection.

\subsubsection{Enforcement issues}

Apart from the prerogatives of the public prosecutor, and the judicial police vested with general enforcement competence, the officials under oath in every administration in charge of the environment and other administrative units concerned are in charge of the research and establishment of infringements in view of implementing the legal framework governing their domain of interest. They must ensure the implementation, control and sanction of any defaulter of the regulations in force. For instance, the administration in charge of the environment must ensure the implementation of the laws and texts that are destined for environmental protection. In this light, they must be able to identify and prosecute infringers of these legal norms. This same responsibility must be shouldered by the administration in charge of water, energy resources, and mines, for instance, when it comes to the implementation of the laws in those sectors. Nevertheless, every administration is responsible for the application of all the regulations in force in every sector of activity to which it is party or is connected. This is contained in Article 88 of the 1996 Framework Law on Environmental Management which provides that: (1) without prejudice to the prerogatives of the public prosecutor, and the judicial police vested with general competence, the officials under oath in the administration in charge of the environment and other administrative units concerned, especially those of the cadastral survey, town planning, public works, forests, the merchant, mines, industry, labour and tourism services will be in charge of the research and establishment of infringements in keeping with the provisions of this law and its enabling instruments; and (2) the officials mentioned in subparagraph (1) above will take an oath before the competent court, upon the request of the administration concerned. Similar provisions can be found in Article 202(1) of the Mining Code. ${ }^{221}$

One of the difficulties in matters of soil protection is the issue of enforcing the implementation of the texts in force owing to inadequate monitoring and poor communication between concerned ministries. In addition to these implementation challenges, the law enforcement agents are engaged in corrupt practices that make the enforcement

221 Law No. 2016/017 of 14 December 2016 repealing Law No. 001 of 16 April 2001 establishing the Mining Code and its modification by Law No. 2010/011 of 29 July 2010. 
of the relevant provisions of the agricultural regulations and other legislation difficult, and by extension, onerous to achieve sustainability in the agricultural sector.

\subsubsection{Monitoring}

In its organisational framework, the ministry in charge of environment carries out services in respect of environmental monitoring. In effect, the services relating to ecological monitoring and follow-up of climate in this ministerial department have the mission to conceive and put in place an ecological survey and alert system; elaborate, establish and follow-up on programmes relating to climate change; elaborate strategies for environmental surveys; elaborate and put in place the policy for information concerning the environment, nature protection and sustainable development; manage the systems of geographic information on the environment, nature protection and sustainable development; serve as liaison between the networks and information systems existing in the environmental sector, nature protection and sustainable development, both at national and international level; put in place and animate a platform for informationsharing between the focal points of international agreements and conventions in matters of environment, nature protection and sustainable development; centralise data relating to information and documentation in all sectors of the environment; and participate in the prevention and management of natural or anthropic disasters.

See generally, Article 45 of Decree No. 2012/431 of 1 October 2012 relating to the organisation of the ministry of environment, nature protection and sustainable development. Again, corruption, lack of information and available data, as well as poor communication between concerned institutions, render monitoring very difficult, with serious implications for soil degradation.

\subsubsection{And what's more?}

There is also the National Agriculture Investment Plan (PNIA) for the period 20142020, which is the agricultural subsector of the National Rural Sector Development Strategy. ${ }^{222}$ PNIA targets second-generation agriculture to increase the growth rate by at least $10 \%$ by 2020 , at an estimated cost of CFA F3,351 billion. ${ }^{223}$ Four thematic areas are involved: (1) develop the production sector and improve food safety and nutrition; (2) modernise production infrastructure in rural areas and improve access to

222 See Ministry of Environment, Protection of Nature and Sustainable Development, 2018, The national strategy for reducing emissions from deforestation and forest degradation, sustainable management of forests, conservation of forest and enhancement of carbon stocks, (National REDD+ Strategy), Final Version. Ibid. 
finance; (3) manage sustainably and use natural resources; (4) practise good governance and institutional development. A series of incentives, particularly tax exemptions, have also been initiated to improve the agricultural sector. ${ }^{224}$ These will have positive impacts on soil protection. The problem here is that second-generation agriculture targeted by PNIA may be carried out on an unsustainable basis by the use of non-homologated fertilizers, chemicals and phytosanitary plant products which are harmful to soils. Corruption, inadequate monitoring and inadequate communication between concerned institutions must therefore be addressed in order to ensure the protection of soils in the implementation of the PNIA.

The strength of these legal and policy instruments lies in the fact they all envisage and seek to protect soils against chemical inputs and also to ensure the sustainable management and use of soil as a natural resource. Notwithstanding their strength regarding soil protection, these instruments also have some weaknesses that lead to soil degradation. For instance, in order to realise the objectives of increasing agricultural productivity, these laws and policy instruments promote actions that put more pressure on soils through forest clearance and encroachment on other natural ecosystems that protect soil, and also by way of more chemical inputs with soil degradation as the direct consequence. Another critical challenge is the problem of implementation and enforcement of the legal texts in the domain of agriculture.

\subsection{Mining}

Cameroon is one of Africa's most attractive new destinations for mining. In this respect, the government has developed a minerals policy to ensure the continuous development of the mining industry in the quest to diversify the economy and harness the natural resources for the development of the country. Mining operations take place in the natural environment, with serious threats to soil quality. Although legislation ${ }^{225}$ governing mining activities in Cameroon addresses environmental problems, such as soil degradation, and provides for soil protection, it also contains some weaknesses that incentivise soil degradation. The Mining Law regulates the search, discovery, exploitation, detention, transportation, transformation and commercialisation of mineral substances. ${ }^{226}$

224 Ibid.

225 Law No. 2016/017 of 14 December 2016 repealing Law No. 001 of 16 April 2001 establishing the Mining Code and its modification by Law No. 2010/011 of 29 July 2010.

226 See Article 1. 


\subsubsection{Relevant legal provisions}

In connection with the protection of soils, the relevant provisions of the Mining Law ${ }^{227}$ seem to be the following: Article 69 institutes the requirement for a mining licence or permit to be obtained by any miner or by a landowner mining quarries for purely domestic use. Quarrying for domestic use is obligatorily subject to regulations governing health, safety, labour and the environment. Under Article 123, landowners are entitled to compensation stemming from, among others, damage caused to the natural surface of the land. Article 126 provides for the establishment of protected zones and closed zones aimed to protect buildings, agglomerations, cultural sites, burial grounds, places of endemism, tourist sites, water points, communication routes, civil engineering works, public utility works, archaeological sites, agricultural concerns, and protected areas, by the minister in charge of mines in conjunction with the relevant government services and prohibits mining or quarry activities within such zones. Similarly, Article 127 prohibits prospection, exploration or mining without authorisation from the competent authorities around built property, villages, houses, protected areas, wells, religious buildings, burial grounds and places considered sacred, without the consent of the owner, and also around communication routes, water pipes, energy and sundry substance carrier systems and, generally, around all public utility sites and civil engineering works. Article 135(1) provides that any mining and quarry operation undertaken (1) must comply with the laws and regulations in force relating to sustainable environmental protection and management; and (2) is subject to the granting of all mining and quarry permits and titles apart from the nonindustrial mining licence, and to the prior conduct of an ESIA and a hazard and risk assessment, and the provision of an environmental management plan as provided for by the laws and regulations in force in matters relating to the protection and sustainable management of the environment.

Article 136 provides for the restoration, rehabilitation and closure of mining and quarry sites, including removal of any mining or quarry plant found on the land. In order to ensure the rational use of mineral and quarry resources in line with environmental protection, Article 137 requires holders of mining and quarry titles to prevent geo-hazards and geo-disasters; prevent or minimise the discharge of waste in the open; protect fauna and flora; promote or maintain the general health of the population; reduce waste; dispose of non-recycled waste in such a manner as to ensure the safety of the environment, after informing and receiving the approval of the authorities in charge of mining and the environment; and manage waste in accordance with the laws and regulations in force. Article 138 requires mining companies to ensure the rehabilitation and closure of mining and quarry sites and proper management of waste to ensure safety of the environment; reduce waste; prevent geo-hazards and geo-disasters; and

227 Law No. 2016/17 of 14 December 2016 relating to the Mining Code. 
also requires holders of mining or quarry permits to dismantle, in accordance with standard rules, any mining plant liable to payment of duties and taxes. Article 140 requires buildings, outbuildings, wells, galleries and all structures, in general, built and used for the mining or quarry activities to be secured, in accordance with conditions set out in the ESMP and the rehabilitation programme of the mining sites at the end of mining or quarry activities.

We have selected these articles to demonstrate how the legislator intends to maintain the environment through the protection of people and the environment itself.

\subsubsection{Monitoring}

With regard to the supervision, control and inspection of mining activities, Article 196 provides that sworn civil servants, inspectors and assistant inspectors of the ministry in charge of mines and other relevant authorities or any duly authorised body will supervise and control mining activities within the limit of their prerogatives. Be these provisions as they may in relation to soil protection and related issues, the same regret as was expressed earlier also applies here, namely that this piece of legislation is not being applied for want of an enabling instrument. For example, Article 199 provides that the conditions for supervising and controlling mining, quarries, and spring, mineral and thermo-mineral water tapping activities, as well as the mining of geothermal deposits, and appointing inspectors and assistant inspectors of the ministry in charge of mines will be laid down by regulation. The enabling instruments of this law are still to be signed and published. These instruments are aimed at enhancing the effective implementation of this law. This is one of the difficulties in the legislative crafting process in Cameroon.

\subsubsection{The role of foreign investors}

The role of foreign investors in the mining sector is significant. In effect, Cameroon does not possess the technical equipment and the necessary technology for mineral exploration and exploitation. Consequently, the country always solicits the intervention of foreign investors. These investors have to comply with the regulations in force relating to their line of activity. The government encourages national investors to collaborate with the foreigners in a bid to ensure transfer of technology and know-how. Unfortunately, these foreign investors are not usually very concerned about environmental protection. It has been noticed that these investors are usually in no hurry to obtain environmental authorisation before launching their activities. This is why, once a site has been exploited, the investors care little about reinstating or rehabilitating the exploited site. These dilapidated sites constitute a threat to the host populations and 
lead to soil degradation. Moreover, foreign investors - as well as national investors use chemical products that are unhealthy for people and the environment, such as mercury. This substance, used illegally on sites, is dangerous for the host and local populations. It pollutes the water used by people and also destroys the attendant biodiversity in soils.

From the forgoing, we realise that the responsibility for environmental degradation, notably soil degradation, is shared between the state and the other stakeholders, being the explorers and exploiters. Regarding the strength of mining legislation with respect to soil protection, the numerous Mining Code articles, as stated above, require mining and quarry operations to comply with the laws and regulations in force relating to sustainable environmental protection and management. The essence of these environmental and social management practices for mining and quarry activities is to ensure soil safety, fertility and the physical prospects of the mining site. In general, these provisions require holders of mining and quarry permits to ensure that mineral resources are exploited rationally and in harmony with environmental protection. The provisions cited above are therefore relevant for soil protection.

Notwithstanding the strength of the Mining Code regarding soil protections, it also has some weaknesses that act as a potential driver of soil degradation. The weaknesses lie in the fact that the code is not being applied owing to the lack of an enabling instrument. As pointed out, this is one of the shortcomings in the legislative crafting process in Cameroon, at least as it concerns natural resources and environmental management in general and soil protection in particular. The question is: What accounts for this very disturbing situation? One may be tempted to think that the government which is in charge of the subsidiary legislation (regulatory instruments) deliberately delays the process in order to frustrate the implementation of laws passed by Parliament, as some provisions may be seen as working against the government agenda or the usual government inertia may be at play. Again, the question is: Was the making of the law conditionality from international monetary institutions, like the World Bank or the International Monetary Fund, for an application/negotiation of a loan for development plans in this area? We must, however, be quick to appreciate the fact that, unlike the previous legislation on the subject, this one has considered governance benchmarks in terms of disclosure principles and this, of course, could render greater service to soil protection than was previously the case. That notwithstanding, the question raised regarding the non-application of the Mining Code due to the absence of an enabling instrument is: What can be done to make good the situation? This may be remedied by either enacting complete and detailed legislation that does not require an enabling instrument, or the law and its enabling instrument could be crafted at the same time so as to facilitate the understanding and the immediate implementation of the law. 


\subsection{Industrial development}

Generally, Cameroon is characterised by a very low level of industrialisation. However, the government has committed itself to becoming an emerging economy by 2035 , and industrial development has a major role to play in achieving this goal, as outlined in Vision 2035 and the GESP that serve as the country's compass for emergence by 2035. The GESP with a strong focus on making Cameroon an industrialised nation thus becomes a key driver of this vision. Cameroon is also endowed with rich natural resources that will provide industries with raw materials. This government ambition may mean increased pressure on the environment, especially the soil. At present, there is no specific legislation governing the industrial sector in Cameroon. The sector today is regulated through a plethora of laws and regulatory instruments governing other sectors. Concerning the treatment of industrial and other wastes that are dangerous to the soil, the following legislative provisions are relevant in the context of this assessment.

Article 47(3) of the 1996 Framework Law on Environmental Management regulates the treatment of special industrial waste which, by reason of its properties, is dangerous, and may not be deposited in storage facilities receiving other categories of waste. Article 54 of the same law provides for the regulation of classified establishments, factories, workshops, depots, building sites and, in a general way, the industrial, craft or commercial installations that may be dangerous to health, safety, public health, agriculture, nature and the environment in general, or disadvantages for the convenience of the neighbourhood. In the same spirit, the 1994 Forestry Law in Article 18 forbids the dumping of any toxic product or industrial waste in national forests, public waterways, lakes or sea without obtaining the prior permit of the government, and without their proper treatment. Article 4(1) of the Water Code prohibits spills, discharges, jets, infiltrations, landfills, spreading, direct or indirect deposits in the waters of any solid, liquid or gaseous material and, in particular, industrial, agricultural and atomic wastes that are liable to alter the quality of surface or groundwater or seawater within territorial boundaries; harm public health and aquatic and submarine fauna and flora; and jeopardise the economic and tourist development of the regions.

Article 2(1) of Order No. 002/MINEPDED 228 calls on every generator and/or operator in the field of industrial waste (toxic and/or dangerous) to provide at the end of the semester to the administrations in charge of the environment a declaration containing a summary of the information of different manifestos. Article 3 requires any operator of an installation that annually generates more than two tons of such waste to provide the administration responsible for the environment with a management plan for the waste. Article 4 obliges every carrier of such waste to use a manifest of

228 Order No. 002/MINEPDED of 15 October 2012 fixing the specific conditions for the management of industrial waste (toxic or hazardous). 
traceability of the waste according to the form in force. Article 5 requires sworn agents of the administration in charge of the environment to prescribe samples and analyses to check the conformity of the loading to the manifest. Articles 6 to 9 provide for the requirements to be met by the generator or shipper of such waste before and during transportation and the conditions under which such waste is transported. Under Article 10 , any breach of one or more of the obligations incurs the responsibility of the operator involved.

The Prime Ministerial Order fixing the conditions for the sorting, collection, transport, recovery, recycling, treatment and final disposal of waste ${ }^{229}$ also applies to industrial waste. The relevant provisions include: Article 9 subjects those involved in the collection, transport and storage of industrial waste (toxic and/or dangerous) to obtaining an environmental permit issued by the administration in charge of the environment. Article 10 requires the transport of such waste to be accompanied by a manifest of traceability of the waste delivered by the administration in charge of the environment. Article 11 requires every generator, collector, transporter or destroyer of industrial waste (toxic and/or dangerous) to keep a register in which it records the type, nature, quantity, characteristics of danger, and origin of the hazardous waste which it has produced, collected, stored, transported, recovered or disposed of. This register is subject to the control of the administration in charge of the environment.

The Prime Ministerial Order specifying the modalities of protection of surface water and underground water against pollution ${ }^{230}$ similarly prohibits in Article 3(1) the spills, discharges, seeps, landfills, spreading, direct or indirect deposits in water of any solid, liquid or gaseous material and, in particular, any industrial, agricultural or atomic waste likely to alter the quality of surface or groundwater or seawater within the territorial limits; to harm public health, aquatic, submarine and land fauna and flora; to jeopardise the economic and tourist development of the regions; and to harm the quality of life and the comfort of residents. Subsection 2 of this article prohibits the discharge, dumping or depositing in surface water, in public sewers or in artificial waterways any solid waste, even if previously subjected to mechanical grinding, any water or other fluids containing such materials or substances, any oils, lubricants and other substances resulting from the cleaning and maintenance of motor vehicles, combustion engines and similar machinery, and any slushes and pesticides.

The concerns relating to soil protection and landownership are also taken on board in the new Petroleum Code ${ }^{231}$ in Articles 4, 57 to 77, 91 and 92. The most relevant provisions are: Article 4(1) and (2) requiring any physical or corporate persons, including landowners wishing to carry out petroleum operations, to obtain prior

229 Decree No. 2012/2809/PM of 26 September 2012 fixing the conditions for the sorting, collection, transport, recovery, recycling, treatment and final disposal of waste.

230 Order No. 2001/165/PM of 8 May 2001 specifying the modalities for the protection of surface water and underground water against pollution.

231 Law No. 2019/008 of 25 April 2019 establishing the Petroleum Code. 
authorisation from the state and to conform to the legislation on land tenure and state lands in force with respect to the attribution of land for exploitation. In view of attributing lands for exploitation, Article 57 requires the holder of a petroleum authorisation to submit a file for land inquiry, the aim being to identify the status of the parcels of land covered by the authorisation; to carry out a census of those who have rights on the parcel of land in question, and to inform them of the modalities for payment of indemnities as a result of loss of their rights; and to sensitise the surrounding population about the petroleum activity. Article 91 requires holders of petroleum permits to carry out petroleum operations in such a manner as to ensure, under all circumstances, the conservation of natural resources, in particular hydrocarbon deposits, and due protection of essential features of the environment. In this respect, holders are required to take all the necessary measures to preserve the safety of persons and property, and to protect the environment, natural surroundings and ecosystems. Article 92(1) requires holders of petroleum contract to carry out ESIAs with respect to the laws and regulations applicable in matters of environmental protection in order to evaluate the direct or indirect impacts of petroleum operations on the ecological balance of the surrounding areas, the people's living environment and quality of life, and the environment in general. Under subsection 2, the ESIA is to be submitted for public inquiry, where such a procedure is required. Subsection 3 provides that the terms and conditions for implementing the provisions of this Section, in particular the list of petroleum operations, the performance of which is subject to an impact assessment, the contents of the assessment, as well as the conditions under which it is made public, is laid down by regulation.

The legislation described above is the most recent piece of legislation touching on soil protection by implication. Compared to the 1999 Petroleum Code, ${ }^{232}$ the present code does not contain innovations in terms of the soil protection paradigm as its provisions have no direct reference to soil apart from general environmental protection provisions. The importance of soil is therefore neglected by this code. Another main shortcoming is, as with other legislation, the lack of enabling instruments needed to complete and implement the law, especially the provisions relevant to soil protection. Furthermore, in the context of environmental protection, Article 30 of Law No. 2012/006 of 19 April 2012 to institute the gas code indirectly protects the soil from all related gas activities, which obliges the operator to comply with environmental protection and safety regulations in force, as well as with internationally accepted environmental protection and safety standards. Law No. 2011/25 of 14 December 2011 on the valorisation of associated gases equally provides indirect protection to soil in the context of environmental and ecosystem protection under Article 11.

Despite the existence of these regulatory instruments which indirectly govern the industrial sector, we still find effluent or liquid and gaseous discharge of industrial

232 Law No. 99/013 of 22 December 1999 to institute the Petroleum Code. See Articles 82 and 83. 
origin, treated or untreated, discharged directly or indirectly into the environment in some major cities such as Douala, which may be harmful to soil health. In the absence of appropriate policies and regulations that balance industrial development with environmental exigencies, such development may have negative impacts on the ecosystem resulting in increased deforestation, and emission of harmful gases and industrial spillage leading to soil degradation. There is therefore the need to develop a legal instrument that will govern industrial development in Cameroon. The government should mainstream environmental concerns especially the protection of soils in such an instrument. Cameroon has elaborated and validated its National Industrialisation Plan aiming at translating into practical terms Cameroon's ambition of becoming an emerging economy by 2035 . The Plan focuses on three key areas referred to as 'industrial sanctuaries' consisting of agro-industry; energy and digital and five industrial pillars consisting of forest and timber; textile/confection/leather; mining/metallurgy/iron and steel industry; hydrocarbons/petrochemicals/refining; and chemical/pharmacy. These targets all have implications for soil degradation. This therefore requires strong regulation with a particular objective to protect the soil.

\subsection{Demographic growth, urban sprawl and land-planning regulatory frameworks}

Population increase manifested in the form of urban sprawl is one of the major drivers of environmental degradation, including soil degradation. In fact, demographic growth is putting enormous pressure on the environment through different human activities that are causing soil degradation. Rapid increase in the population coupled with rapid urbanisation has led to significant transformation of natural ecosystems such as forests and wetlands into habitable spaces as well as for industrialisation and agricultural purposes to meet up with food production. These are exerting enormous pressure on natural ecosystems, exposing the soil to various forms of degradation. Urban and spatial planning laws and policies in Cameroon, at least in theory, guarantee sustainable management of natural resources, the environment and the soil in particular. Such planning laws and policies ought to help direct certain activities away from ecosystems that need special protection. The development policy of Cameroon establishes a decentralised approach to natural resources and environmental management. The 1996 Constitution introduces decentralised authorities, whose role is to promote the economic, environmental, social and cultural development of their peoples in line with the principle of sustainability. Thus, in the general framework of decentralisation in Cameroon, one may cite Law No. 2011/008 of 6 May 2011 on the orientation of planning and the sustainable development of the territory of Cameroon. Article 1 of this law sets out its objectives in terms of defining the general legal framework for national spatial planning from the perspective of sustainable development and coverage of all operations relating to the occupation of space, the allocation or balanced distribution of activities, 
infrastructures, equipment and services in the national territory. To achieve these objectives, the law prescribes concerted and participative development and the implementation of strategic planning and sustainable development tools, based on the needs and available resources, strategic choices and options for coherent regional or subregional development across sectors. ${ }^{233}$

The implementation of regional development policy is also guaranteed by specific regulations, including: Decree No. 77/193 of 23 June 1977 establishing the urban and rural land development and equipment administration; Decree No. 79/189 of 17 May 1979 establishing the rules and regulations governing the demarcation of urban boundaries; Decree No. 79/194 of 19 May 1979 establishing the rules governing the creation of schemes; Decree No. 81/185 of 4 May 1931 establishing rules governing the creation of special layouts by the development of urban and rural land; and Decree No. 79/PM of 10 July 1981 allocating parcels of special provisions.

Upon adoption, the National Land Use Planning for Sustainable Development Scheme (Schéma National d'Aménagement et de Développement durable du Territoire - SNADDT) will also be instrumental with respect to the protection of soils as it has an impact on soil. The first phase of the SNADDT identified and zoned the entire territory according to resources and development potential. The second phase is in the process of producing a national indicative land-use plan. Currently, regional land-use plans are being prepared. In addition, the current investment plan to enhance municipal council land-use plans promoted by the National Participative Development Programme is an important planning policy with direct implications for soil and therefore, should align with soil protection objectives. Furthermore, Articles 16 and 17 of Law No. 2004/018 of 22 July 2004, fixing the rules applicable to councils, make provision for the protection of the soil by councils. In the same manner, Article 19 of Law No. $2004 / 019$ of 22 July 2004, fixing the rules applicable to regions, makes provision for the protection of the soil by regions in the framework of environmental and natural resources management. Thus, the urban and spatial planning laws and policies influence land use and natural resource management policies with direct implications for soil protection.

Notwithstanding the foregoing, the current land planning regulatory framework is not being felt on the ground and makes it difficult to protect soils, partly owing to lack of direct references to soil and also because of implementation challenges. The implementation challenges stem from poor coordination between the concerned ministerial departments. There is therefore the need for regulatory reforms that would make it easier for project implementers to engage in sustainable activities that protect soils. One way to do this is to develop and implement a strategy, to formulate legal and institutional frameworks for spatial planning in a participatory manner, taking into account sectoral objectives, and to enhance the capacities of stakeholders.

233 See Article 3(1). 


\subsection{Climate change law and soil degradation}

As discussed in Chapter two, climate change is one of the major causes of soil degradation and soil is one of the natural solutions to mitigate climate change through its carbon sequestration and storage functions. Unfortunately, Cameroon presently has no specific climate change legislation that addresses these issues. Thus, despite the symbiotic relationship between soil and climate change, both international and national politics on climate change have paid little attention to the importance of soil as a natural means of combating climate change and the corresponding negative effects of climate change on soil. The lack of a specific reference to soil as both a sink and source of GHGs in the UNFCCC, the Kyoto Protocol, ${ }^{234}$ the PCCA and any other related international and national instrument demonstrates the lack of political will to give more attention to the impact of climate change on soil and also the relevance of soils in fighting climate change.

However, in the absence of a specific climate change law, Cameroon has developed a good number of policy documents to prepare for and implement the REDD+ initiative that was developed and implemented since 2005. Relevant national policy documents and progress in this respect are the 2008 R-PIN and the 2013 R-PP, the NDCs submitted in 2015 to the secretariat of the UNFCCC, and the 2018 National REDD+ Strategy that were prepared in view of the national implementation of the REDD+ initiative. Although there is no direct reference to soil in the R-PIN and the R-PP, the documents clearly identify slash-and-burn agriculture in the context of fighting climate change as one of the main sources of deforestation and GHG emissions in Cameroon - which is also a main driver of soil degradation. The R-PP further identifies bushfire as a driver of soil degradation. The two policy documents are therefore relevant for soil protection in Cameroon. Further, the NDCs spell out the actions Cameroon intends taking to address climate change - both in terms of adaptation and mitigation. Originally submitted as INDCs, they became binding NDCs upon the ratification of the PCCA. Via its NDCs, Cameroon has pledged a 32\% reduction in its GHG emissions by 2035 compared to business-as-usual levels, taking 2010 as the reference year and conditional upon international support in the form of financing, capacity-building and transfer of technology. Through its NDCs, Cameroon intends to reduce its development carbon footprint without slowing its growth, identifying the soil as a critical component in meeting its $32 \%$ carbon emission reduction pledge. The NDCs therefore provide for good soil management practices through, for instance, restoration. ${ }^{235}$

In terms of soil protection, the National REDD+ Strategy clearly identifies the implementation of a programme on landscape restoration and management for climate

234 Adopted in Kyoto, 11 December 1997, UN Doc FCCC/CP/1997/L.7/add.1, entered into force in 2005 .

235 See Republic of Cameroon $(2015: 4,5)$. 
change resilience in the Northern Regions through the restoration of degraded soils by setting up private plantations for the production of wood energy; and regaining soil fertility and water catchment protection through agroforestry techniques. In the framework of promoting sustainable agricultural systems, the National REDD+ Strategy makes recommendations for regaining soil fertility and water catchment protection through agroforestry techniques; promoting food crops with low deforestation and forest degradation effects; allowing carbon conservation and sequestration (cocoa and coffee growing, etc.); promoting certification of agricultural products; promoting biofertilization through the recovery of agricultural residues; restoring and enhancing village hedges around agricultural land; recovering of fallow land; and, for agro-sylvopastoral landscape management, supporting of pastoral landscape management (securing and improving pastures to reduce the incidence of bushfires). ${ }^{236}$ As of now, one may say that the only challenge with the implementation of the National REDD+ Strategy is securing international support in the form of adequate financing, capacity-building and transfer of technology.

Cameroon has a national climate change observatory. This structure has the mission to, among others, follow up the evolution of the climate and alert the government of ecological, sanitary and environmental threats that may be caused by climate change. To this effect, the organ collects information relating to climate and then elaborates and publishes a bulletin of alerts on climate. Despite the relevance of these initiatives for the protection of soil, the importance of soil especially as a carbon sink needs special and specific legal protection. A key message is that climate change is a major threat to soil degradation and soil is also critical for climate change mitigation - which requires that the policy on climate change and soils be appropriately designed to address these challenges.

\subsection{Land tenure insecurity: Relevant legal provisions and associated problems}

Land tenure insecurity is an important underlying factor of land and soil degradation. The following points constitute the relevant legal provisions and associated challenges in terms of soil protection.

236 Cameroon's National Strategy for reducing emissions from deforestation and forest degradation, sustainable management of forests, conservation of forest and enhancement of carbon stocks, 2018. 
4.6.1 Ordinance No. 74/2 of 6 July 1974 establishing the rules governing state lands

Ordinance No. 74/2 governs the public and private property of the state as well as those of other public bodies as contained in its Article 1. This ordinance also enables us to make a distinction between the different types of public properties - i.e., natural and artificial public properties. Natural public property comprises coastlands, waterways, subsoil and airspace. Our interest in this exercise is on the maritime property, landed public property and fluvial public property. In effect, the maritime public property comprises, among others, the soil and subsoil of territorial waters. Even though such property is not exploited by the ordinary population, there is some human presence associated with it, which can be seen through offshore petroleum exploitation and through the disposal of different types of waste, notably plastic waste and any other pollutant affecting this type of property. Landed public property comprises the subsoil. This text therefore showcases the principle of devolution of the subsoil for purposes of its exploitation or its valorisation. The expression 'devolution' here is employed to mean the legal transfer of property from one owner to another. Waterways or fluvial property comprises, among others, marshland. Ordinary populations are usually forbidden from putting such property into use. Such land is considered by Cameroonian law as non aedificandi zones, which means lands on which activities such as the construction of buildings are forbidden.

\subsubsection{Ordinance No. 74/1 of 6 July 1974 establishing the rules governing land tenure}

Just like the previous ordinance on state lands, Ordinance No. 74/1 establishing the land tenure regime lays down the basic principles on the basis of which one can acquire ownership of land. In effect, Article 1(1) of this piece of legislation provides that: "the State guarantees to all-natural persons and corporate bodies having landed property the right to freely enjoy and dispose of such lands". Article 1(2) further makes the state the guardian of all lands and may in this capacity intervene to ensure rational use of land or use of land in the imperative interest of defence or in accord with the economic policies of the nation. This text makes it possible for every physical or corporate body whether of Cameroonian or foreign nationality to acquire land in Cameroon. Unfortunately, it is the application of this provision through the procedure for acquisition of land title over pieces of land that causes some trouble to the populations. These troubles, for instance, include the onerous cost of obtaining land title as well as the formalism associated with it.

In addition, such a general provision has eased the path and procedure for what is now a disturbing situation of 'land grab'. Land-grabbing is the controversial issue of 
large-scale land acquisitions involving the government leasing large parcels of land to big corporations, mostly of foreign origin, or influential national elites buying and registering large expanses of land in local communities. ${ }^{237}$ Tafon and Saunders note that: ${ }^{238}$

the widespread leasing or sale of lands in the developing world to foreign Governments and companies and to locally owned companies, or the appropriation of such lands by national or local Governments commonly known as land grab has intensified in recent years.

It has also been asserted by Amin and Jaha that this mode of land acquisition constitutes a pattern of economic dispossession throughout the global South. ${ }^{239}$ There are numerous cases of land grabs, dispossession and evictions of communities across the country with implications for soil degradation.

The Herakles Farms plantation in the South West Region of Cameroon is one of the well-documented examples involving massive land grabs and environmental problems such as soil degradation. In 2009, the Cameroonian subsidiary of Herakles Farms SITHE Global Sustainable Oil Cameroon (SGSOC) - signed a convention with the Government of Cameroon to develop a large-scale palm consisting of a 99-year lease for 73,086 hectares of land in the Ndian and Kupe-Manenguba Divisions. Local civil society organisations such as the Upper Balung Cultural and Development Association group representing seven villages mobilised to oppose the project, but with stiff resistance from state institutions. It is reported that SGSOC cleared more than 882 hectares of forest, with serious soil degradation and other environmental problems. The company was further accused of manipulating the content of its EIA to hide the plantation's true impacts and that the company's high conservation value assessment was forged by a panel of experts. SGSOC has also been accused of violating communities' rights to free and prior informed consent by engaging in corrupt land negotiation processes and demarcating its plantation boundaries without consent from locals in Nguti and, in the process, clearing farmlands belonging to communities. The actions of a coalition of over 20 Cameroonian and international NGOs opposing SGSOC's unethical and illegal behaviour were abortive. In fact, it is reported by some researchers ${ }^{240}$ that two Cameroonian NGOs - the Struggle to Economise Future Environment and Nature Cameroon, based in the plantation area, suffered administrative and judicial harassment by SGSOC and the Cameroonian Government.

Another case is the Bakweri Land Problem and the Privatization of the CDC. As highlighted by Tande, in reaction to the ministerial visit in early 1999 to consider the planned privatisation of the $\mathrm{CDC}$ which had not addressed most of the key concerns of the local population, the Bakweri Land Claim Committee addressed a memorandum to the Cameroonian President in March 1999, in which it reiterated the 50-year-old

239 Amin \& Jaha (2016: 19).

240 See Fraser \& Mousseau (2016: 3); Tafon \& Saunders (2019: 50); Ndi (2017). 
Bakweri claims to the lands on which the $\mathrm{CDC}$ had established its agro-industrial complex after the Second World War. ${ }^{241}$ The committee demanded, among other things, official recognition that the CDC lands historically and legally belonged to the natives of the Fako Division. ${ }^{242}$ In the course of the debates a general agreement was arrived at that the CDC should not be privatised without addressing the long-standing grievances of the Bakweri people, and that being an integral part of their lives, the CDC should not be sold to third parties without taking into account their interests for which the corporation had been established by the British Government. ${ }^{243}$ In 2007, some indigenes from 19 villages of the Bakweri tribe in the Fako Division attempted to uproot banana plants on 15 hectares of a CDC plantation at Liongo, claiming that the health hazards of CDC's economic activities on their children, together with its expansionist and expropriationist tendency towards their ancestral lands provoked their hostility. ${ }^{244}$ This long conflict was over the ownership, control and use of over 250,000 hectares of ancestral lands from which they had been evicted and relocated to a strange land, where they were deprived of their old hunting grounds and fishing rights. ${ }^{245}$ While the Bakweri indigenes had been struggling for decades to have their land rights restituted, the government consistently exerted its authority by invoking the land law of 1974 which declares, among others, that "the State shall be the guardian of all lands". Thus, as highlighted by Tande and Ngwoh, while the Bakweri Land Claim Committee members continued to cite this same law as a confirmation of their customary ownership, the state remained adamant. ${ }^{246}$

According to Lang, religious groups in the country are also associated with the phenomenon of land-grabbing, which has been blamed on the generosity of the land tenure legislation. ${ }^{247}$ We beg to differ with this researcher and take the view that the acquisition of lands by the church during the colonial era cannot actually be considered as land grab in the contemporary understanding of the concept. Moreover, unlike the socalled land-grabbers and actors in land and soil degradation, churches are not involved in activities that degrade the soil. Therefore, one may convincingly argue that the church is not a land-grabber and certainly not an actor in soil degradation in Cameroon. That said, land acquisition by churches can be blamed on the generosity of early traditional rulers who carved out large portions of their chiefdoms and fondoms and allocated them to the missionaries. An important goal of the church's mission in Africa was the acquisition of land required for the provision of public services, such as schools, health facilities and cemeteries, which made the church owner of relatively

241 See Tande (1999).

242 Ibid.

243 See generally Tande (1999) and Ngwoh (2019).

244 Ibid.

245 Ibid.

246 Ibid.

247 See Lang (2017: 120). 
large parcels of land in communities across Africa. The most implicated of these churches is the Roman Catholic Church, which enjoys a nationwide presence and occupies land in most communities for its numerous evangelical, economic and social engagements. The church has acquired large expanses of land across the country for its huge holistic mission, with associated disputes, most of them over boundaries. According to Lang, a contributing factor to land boundary disputes in Weh was the expansion of the Catholic Church in the Weh community, whose theology went beyond worship, manifesting huge interest in land acquisition. ${ }^{248}$ Other instances of land conflicts involving the church have been noted in villages such as Esu, Njinikom, Nkwen, Nso and Baseng. Former President of Kenya, Jomo Kenyatta, is well known for his assertion that:

When the missionaries came to Africa, they had the Bible, and we had the land. They said let us pray. We closed our eyes. When we opened them, we had the Bible, and they had the land.

The interpretation of this quotation is that the missionaries came to Africa under false pretences. Their real purpose was not to teach the Bible but to lull the people into piety while pursuing their real objective of taking and owning their lands.

The high economic value presently placed on land and its appurtenant resources ${ }^{249}$ has invariably increased the tendency of the most powerful to engage in land-grabbing in Cameroon and beyond, to the detriment of the vulnerable groups. ${ }^{250}$ These vulnerable groups are increasingly being displaced from their lands, stirring disputes and sometimes bloody conflicts, with devastating effect on all parties involved. In fact, it has been observed by Lang that customary land tenure systems offer weak security, and the modern land law provides huge opportunities for land-grabbing. ${ }^{251}$ Land-grabbing and dispossession are serious cause of hardship in vulnerable groups. It has been reported that in the North West Region of Cameroon, such as Bui, Wum and Mezam, to name a few, elites, bureaucrats, and cattle graziers use their positions and wealth to amass large tracts of land, on which they establish cattle ranches and plantations. ${ }^{252}$ In many cases, such land grabs deprive the vulnerable groups of land on which they depend for their subsistence.

248 Ibid.

249 Minerals, timber and non-forest timber resources and other related activities such as agricultural development.

250 Local communities and the poor.

251 Lang (2017: 116).

252 Sone (2012). 
4.6.3 Decree No. 76/166 of 27 April 1976 establishing the terms and conditions for the management of national lands

Decree No. $76 / 166$ is the enabling instrument for the application of Ordinance No. $74 / 2$ of 6 July 1974 to establish the rules governing state lands. The decree determines the modalities for the attribution of parts of state lands. The text in Article 1 enables individuals and physical or corporate persons to obtain parts of unoccupied or unexploited national lands for developmental projects by means of a temporary grant of rights, which may become a lease or an absolute grant depending on the circumstances and subject to the provisions of the present decree. Article 2 provides that: "temporary rights shall be granted for development projects in line with the economic, social or cultural policies of the nation". A reading of the provisions above may lead one to the conclusion that national lands may be subject to a temporary grant of rights, which could be a lease or absolute grant, depending on the provisions of the decree. A condition for this to happen as per the decree is that such lands are either unoccupied or unexploited. Article 2 is even more emphatic that temporary rights accruing from the grant must be for development projects that respond to economic, social or cultural policies of the country.

But what does this mean for soil management? These pieces of legislation do not place any limit to the amount of land that can be acquired under the temporary grant and the fear is that such lands, once acquired, may be over-exploited to maximise returns, to the extent that they degrade, since land is granted for a limited period of time. However, the law has placed this limit on the number of years rights arising from such grants could last. This seems to suggest that any renewal could be conditioned on the manner in which the uses answer to economic, social or cultural policies, including soil management dimensions. This is the spirit, in our view, behind Article 3 of the decree, namely that: "the duration of the temporary grant may not exceed five years. In exceptional cases it may be extended on reasoned application by the grantee". In addition, the exploitation of lands under this heading for development projects must be done in accordance with conditions laid down in the environmental and social impact assessment (ESIA), which checks negative impact on the environment including soil conservation.

\subsubsection{Circular No. 001/CAB/PM of 1 April 2014 relating to measures applicable} to investors on access to land

In the hierarchy of norms, circulars are generally not taken into consideration because they do not possess an efficient and evident binding force. In Administrative Law, circulars are of two types, namely interpretative and imperative circulars. The former is a non-Administrative Act and consequently does not create rights and obligations, 
but its legal value lies in the fact that it gives further meaning to the law in terms of a better understanding and therefore eases the implementation of the main Administrative Act. It resembles an enabling instrument to an Administrative Act only from an interpretative perspective. The latter, on the contrary, is imperative/mandatory because it creates rights and obligations for the parties concerned. Such circulars appear to be veritable legal texts based on their contents and the persons to whom they are addressed. This is the situation with the circular in question, which re-establishes the modalities for allocation of lands to investors. The circular is applicable to all the administrations that are involved in the process of allocation of lands for the purpose of a development project. In effect, this 2014 Prime Ministerial Circular comes as a consequence of a number of irregularities and also malfunctioning in the process of allocating lands to investors for the realisation of their projects. The Prime Minister and Head of Government noticed that:

certain administration took engagements in matters relating to land contrary to the legislation and regulations in force (...) while investors requested for the allocation of lands with immature projects, that is to say without prior assessment of the feasibility of the projects and their financing meanwhile it is clear that the evaluation of the first pieces of land is strictly dependent on the technical parameters of the project. He further noticed that huge stretches of land demanded by certain investors are generally used for the mobilisation of important financing, which seriously truncates the role that lands play in matters of development.

On the basis of the foregoing, this circular has been useful in redefining rights and obligations, roles and procedure for the allocation of land to investors and consequently has reduced the land-grabbing phenomenon and the illegal occupation of land by investors. This has undoubtedly had an effect on access to and exploitation of soils.

\subsubsection{Law No. 85/009 of 4 July 1985 relating to expropriation on grounds of public utility and the modalities for the payment of indemnities}

Law No. 85/009 is the most important text in Cameroon relating to the loss of ownership of land. The text enables the state to enter into possession of any piece of land regardless of who the owner is, provided it is for the purpose of a development project that will serve general interest. Article 1(1) provides that: "for the realisation of objectives of general interest, the State may make recourse to the procedure of expropriation on grounds of public utility". This expropriation cannot be done without something in exchange. Article 3(1) in this respect provides that: "expropriation entitles the owner to receive indemnity, be it financial or in kind, in accordance with the conditions laid down by the present law". However, this indemnity will not be paid if the owner is occupied in some illegality in the wording of Article 10(3), such the destruction of buildings that are dilapidated or threatened by ruin or constructing buildings in violation of the urbanisation plan or against legislative or regulatory dispositions on the land tenure regime. 
This text appears to be a framework document in that every act of expropriation on grounds of public utility must be preceded by a specific decree from the President of the Republic or the Prime Minister, Head of Government. While this piece of legislation has been applauded by many as it envisages compensation in cases of loss of ownership on the ground already expressed above, we must not lose sight of the fact that litigations abound and are usually articulated around the modalities governed by these specific decrees for calculating dues and the length of time it takes to pay the dues to the victims. The implication of this legal position for the soil is that the length of time it takes to pay compensation to victims is a factor that may incentivise activities that degrade the soil by disgruntled victims.

\subsubsection{Traditional law}

Traditional law here should be understood as customary law relating to land tenure. We need to state immediately that there is a rich but very slippery debate around customary land tenure in Cameroon, as is probably the case elsewhere on the continent. ${ }^{253}$ That Cameroon is Africa in miniature is as true in the domain of customary or traditional law as it is in other domains. The country has more than 250 ethnic groups, each with its own customs. ${ }^{254}$ The country is therefore very rich in customary or traditional law. In the area of land tenure, customs hold that there is customary ownership of land. It is important to mention that such customary tenure was recognised by law up to 5 August 1974 where the land tenure legislation so provided, but the same legislation stated that, after this date, all lands under customary ownership should be registered or cease to exist under customary tenure. ${ }^{255}$ Of course, this provision could be understood as a transitional measure because before the land tenure legislation was enacted which gives exclusive ownership of land to the state, ownership was purely customary. Therefore, since the coming into force of this legislation, customary landownership ceased to exist. The only rights over such lands now are access and use rights in terms of hunting and fruit-picking, ${ }^{256}$ which can have very insignificant negative impacts on the soils. In fact, this has not been a healthy situation as local communities have continued to claim ownership of lands situated within their localities - the so-called rural lands. The result is a continuous conflict, especially when such lands have to be exploited for public purposes and no compensation is to be paid out to communities as they have no ownership over such lands or when the land is allocated to foreign investors for investment purposes. In very few cases are the inhabitants of such lands

253 Elias (1971).

254 Ngwafor (1996).

255 Article 17(2) of the Land Tenure Ordinance, 1974 read in conjunction with Article 15 classifying land into two categories.

256 Article 17(3). 
resettled. The attempt to ease land registration through the 2005 legislation has provided only meagre satisfactory results.

Completely ignoring traditional undocumented systems, statutory law makes land titles and leases the only legal means of holding property rights to land. In this regard, most lands in Cameroon are classified as national and state-owned, despite centuryold claims by communities. Indeed, there is a general conception that local communities' land tenure rights were established even before the state came into existence. Unfortunately, rural land is hijacked from local communities, making them tenants of the state and subject to state regulation. Formally, most land today, including untitled lands occupied by rural communities, is considered National Land, administered by the state for the public interest. The state can evict communities from these lands and relocate them to guarantee the lands' 'effective exploitation'. Rural communities can title their customary land, and titles are the only protection against such evictions. But communities can only title land that was used and occupied prior to 1974. Neither land occupied after 1974 nor unoccupied non-farmland can be titled, even if it is vital to the community. Land reform in 2005 simplified land titling by reducing the number of steps and departments involved, and cut the time needed to obtain a land title from several years to less than one. Yet, it failed to address significant hurdles, including contradictory legal provisions and poor record-keeping. Sometimes, more than one land title is issued over the same parcel of land, creating conflicts. This can be frustrating and is a potential incentive for unsustainable activities which do not favour soil protection. It is critical that customary ownership by local communities be officially recognised, otherwise they will have little incentive to manage lands sustainably and protect soils. There is a need to strengthen customary landownership. Strengthening customary tenure rights here means the process by which the government legally and unequivocally cedes landownership and management rights to local communities that have historically used and occupied such lands. However, the strengthening of land rights, especially for local communities, should go in tandem with the enforcement and monitoring of the legal reforms.

A new and rampant tendency consists of elites moving to village communities to propose financing the registration of their land. In return, the communities or family members compensate the elites with many hectares of their land. This at least provides some tenure security, compared to customary 'ownership'. However, this has not laid to rest disputes over landownership and use. Today, as the government, elites, agroindustrial companies, and powerful traditional leaders acquire more lands, neither legal processes nor customary tenure systems provide people with adequate security over their land. This can incentivise unsustainable land management by occupiers of land who feel unsecured, which is not healthy for soil protection. 


\subsubsection{Conflicts and means of resolution}

As discussed in Chapter three, there is a variety of land tenure types, giving rise to conflict and unsustainable land and soil management. For instance, there is evidence of customary rules prescribing acceptable claims to lands among members of communities, but where such claims are contradicted or nullified by legislation. Communally owned lands are insecure as such lands can easily be converted into national lands for development purposes. This insufficiency of the law leaves communities vulnerable, which, in turn, may incentivise land and soil degradation by communities who do not feel secured. Lang observed that "this situation of dual co-existing rules causes confusion and difficulties of understanding rules regulating people's rights to land". ${ }^{257} \mathrm{We}$ believe that apart from the customary argument of giving more land rights to groups who depend directly on the lands for their livelihood, it is also likely that if their rights to land are not legally strengthened, they may thwart soil protection and conservation efforts. We also believe that strengthening customary land tenure rights can guarantee legitimacy and local support for soil protection with positive economic, social and environmental derivatives.

In the land dispute involving Nkamgang Mingeu Joseph $v$ The State of Cameroon $(M I N D C A F),{ }^{258}$ the petitioner applied and obtained from the Minister of Lands a parcel of 40 hectares of national land for agricultural purposes. The petitioner claimed that having received a land certificate for the parcel of land, the same Provincial Service of Lands at Buea issued a second land certificate for the same piece of land to another party. The petitioner requested the Administrative Court of the South West Region, among other things, to cancel the latter land certificate, which was fraudulently issued, citing case law ${ }^{259}$ to show that the only remedy for the fraudulent act was to withdraw the second land certificate. The court in its judgment declared the petition unfounded on its merits. This was because the Tiko Court of First Instance had visited the area in dispute in an earlier action for trespass on land by the petitioner against the defendant and in its reasoned judgment found that "the tort of trespass has not been proven against the defendant and third parties on the balance of probabilities". The Tiko court referred the plaintiff and the third parties to the competent Ministry which issued the land certificates for regularisation and dismissed the claim. The petitioner then applied to the Minister of Town Planning and Housing to apply Section 2(3) and (4) of Decree No. 76/165 of 27 April 1976 and withdraw the second land certificate issued on the land, but the Minister did not respond to the pre-litigation complaint. The fact that the Administrative Court of the South West Region did not find either at the site of the

257 See Lang (2017: 118-119).

258 Suit No. SWAC/LPM/006/2014.

259 See CS/CA Judgment No. 10/91-92 of 26/12/1999 Aff. BOLLO ETOGO v Etat du Cameroun (MINUH); -cs/ca Judgment No. 01/87-88 of 29/10/1988 Aff. BASSO Theodore et MAKON Daniel $v$ Etat du Cameroun (MINUH). 
encroachment or in both land certificates any point where both pieces of land overlap, and the petitioner's absence during its visit to the scene of the alleged encroachment were proofs of irregularities that caused the court to declare the petition unfounded on its merits.

In Noumsi Jean Bosco v The State of Cameroon (MINDCAF), ${ }^{260}$ the plaintiff asked the Supreme Court to withdraw and cancel a land certificate obtained eight years after his on the same piece of property. The plaintiff in this case blamed the administration for having mapped out and issued two land certificates on the same property in violation of the principle of "bornage sur bornage revant" (which is the operation by which contiguous landowners agree to recognise the common boundary of their respective landed properties). In its reasoned judgment, the Supreme Court after declaring the petition acceptable in due and proper form ordered the immediate cancellation of the land certificate of the respondent which was obtained eight years after the plaintiff's certificate without the plaintiff's knowledge and under dubious and opaque circumstances.

In Yongo Marc v The State of Cameroon (MINUH) and Delangue Koloko Michel, ${ }^{261}$ the plaintiff asked the Supreme Court to cancel and nullify the land title obtained by the respondent under conditions that were illegal and attributable to the state's error or fault. The Supreme Court, in granting the plaintiff's request, noted the overlapping registration procedures undertaken on the same land as constituting a fault of the administration and the clandestine contract of fictitious demarcation constituting fraud by the beneficiary Delangue Koloko Michel and that the beneficiary's land title had to be withdrawn pursuant to Article 2, paragraphs 3 and 6 of Decree No. 76/165, fixing the conditions for obtaining the land title.

In another land dispute between Watson Mbua Maliva and Jakai Joan Limunga $v$ The State of Cameroon (MINDCAF), Tsamo Souna Christian Josue and Souna Edward ${ }^{262}$ the petitioner requested the court to nullify and cancel an irregular land certificate issued on 13 December 2016 to the respondents on a land surface area of $1,206 \mathrm{~m}^{2}$ covering portions of land allocated to the petitioners by Chief Kaka Daniel, the head of the Bokwai village land management committee, dated 6 August 2012, following the procedure of land surrendered by the CDC. It was also attested that the land certificate was issued amid a serious dispute over the land and contrary to the law in force. The court declared the claim inadmissible because the petitioners failed to mention in their pre-litigation complaint for the withdrawal of the land certificate to the MINDCAF the fact that the portions of land were allocated to the petitioners by Chief Kaka Daniel, following the procedure of land surrendered by the CDC. 
Other relevant decided cases involving land disputes in Cameroon include:

- Suit No. 01/RG/F/016 of 2 February 2016 Ousmanou Dairou v The State of Cameroon (MINDCAF), Judgment No. 08/AFD/ 2017, delivered by the Maroua Administrative Court;

- Suit No. SWAC/LSP/003/2017 The University of Buea (Repr. by the Vice Chancellor) v Bulu Village Traditional Council (Repr. by the Chairman Muambo Etonge Paul), Molinge Etonge Ruben, Ngowona Mba She Marie Benoite, Njume George Ndumbe, Fouejeu Tiogo Gabin, Nanfack Tsiguia Frank and Edembat Claude, Judgment No. 015/2018;

- Suit No. SWAC/PND/001/2016 Barrister Ebai Helen v The State of Cameroon (Repr. by the Ministry of State Property, Surveys and Land Tenure), The State of Cameroon (Repr. by the Ministry of Territorial Administration and Decentralization), the Governor of the south west region and Chief Kombe Simon, Judgment No. 006/2018;

- Suit No. SWAC/LPM/006/2014 Nkamgang Mingeu Joseph v The State of Cameroon (MINDCAF), Sone Ngenye Stephen, Robinson Ebeke Mondo, Ngenye Esoh, and Deutia Noumageu M. (Intervener), Judgment No. 018/2018;

- Suit No. 08/RG/F/016 of 15 November 2016 Ali Née Nkeck Géneviève v The State of Cameroon (MINDCAF) and Hamadou Bako, Judgment No. 03/AN of 6 February 2018;

- Suit No. 1780/03-04 of 8 October 2003 Douala Mouteng née Mbara Angandji Germaine $v$ The State of Cameroon (MINDCAF), Judgment No. 124/2016/TA-YDE of 19 April 2016;

- Suit No. 377/2013 of 11 October 2013 Efila Nnah Jean Gabriel v The State of Cameroon (MINDCAF), Judgment No. 133/2016/TA-YDE of 3 May 2016;

- Suit No. 352/2013 of 19 September 2013 Eya Ateba Sidoine v Etat du Cameroun (MINDCAF), Judgment No. 96/2016/TA-YDE of 5 April 2016;

- Suit No. 259/2013 of 6 June 2013 Mengue Barbare $v$ The State of Cameroon (MINDCAF), Judgment No. 125/2016/TA-YDE of 19 April 2016;

- Suit No. 89/2013 of 5 March 2013 Syndic de la liquidation des Ets Paul Khoury (Ngoua Elembe) $v$ The State of Cameroon (MINDCAF), Judgment No. 131/2016/TA-YDE of 3 May 2016;

- Suit No. 05/2013 of 3 January 2013 Succession Eyenga Marie Gisèle Béatrice (NKIE Laurent Cyrille Martin) v The State of Cameroon (MINDCAF), Judgment No. 130/2016/TA-YDE of 3 May 2016;

- Suit No. 373/06-07 of 16 November 2007 Noah Soter Isidore and others v The State of Cameroon (MINDCAF), Judgment No. 121/2016/TAYDE/ADD of 19 April 2016; 
- Suit No. 41/2010 of 27 January 2010 Nyemb Jean Baptiste v The State of Cameroon (MINFOPRA), Judgment No. 128/2016/TA-YDE of 3 May 2016;

- Suit No. 32/2013 of 25 January 2013 Onana Onana Roger $v$ The State of Cameroon (MINDCAF), Judgment No. 122/2016/TA-YDE of 19 April 2016;

- Suit No. 1569/02-03 of 26 December 2002 Succession feu Amougou Ambroise $v$ The State of Cameroon (MINDCAF), Judgment No. 129/2016/TAYDE of 3 May 2016;

- Suit No. HCN/03/0S/2011 Struggle to Economise Future Environment (SEFE) v S.G. Sustainable Oils Cameroon LTD and Dr. Timti Isidore, Ruling CRNo. 90200251 of 19 March 2012;

- Suit No. 1346/00/01 of 7 August 2001 Dame Nga Etende Atangana Marie Dame Banga Blandine $v$ The State of Cameroon (MINUH) and Société Industrielle de Mbang S.A, Judgment No. 111/2016/TA-YDE of 12 April 2016; and

- Suit No. SWAC/PSE/001/2018 Livanda Village Community v The Minister of State Property, Surveys and Land Tenure, Ruling No. 005/RPSE/PC/2018 on an application for stay of execution.

The importance of resolving land tenure conflicts and ensuring fair ownership, access and use rights for all is critical for soil protection. Land tenure security guaranteed by land titling is crucial for soil protection, especially as the economic interest in land is constantly on the increase due to much pressure from large-scale investors in agroindustries and related activities. Without secure land tenure, users have no incentive to protect lands and soils. Land tenure security will provide a safeguard against risks of unsustainable land practices by unsecured users and will support more effective land and soil management. Land tenure security for communities, in particular, will support the exercise of traditional knowledge and practices that are good for soil protection.

There seems to be no case law regarding appeals on administrative decisions concerning the use or protection of soil other than land disputes. This is probably because the protection of soil is not a major concern in Cameroon, at least for now.

\subsubsection{Land tenure legislation and associated land-grabbing}

Land-grabbing is identified as a main driver of soil degradation. The general provision of the land law states that: ${ }^{263}$

the state shall be the guardian of all lands. It may in this capacity intervene to ensure rational use of land or in the imperative interest of defense or the economic policies of the nation 
has eased the path and procedure for what is now a disturbing situation of 'land-grabbing'. This provision is an enabler of land-grabbing in that it has eased the way for the most powerful (the state, large corporations, the church, influential national elites and the rich) to engage in acquisition of large expanses of land to the detriment of the vulnerable groups (local communities and their poor members). Thus, the generosity of the land tenure legislation may lead to more soil degradation in the country.

\subsubsection{Relationship of landownership and environmental responsibility}

All the regulatory texts on land tenure in Cameroon guarantee ownership, which gives landowners of the three land categories the right to exclusive possession and use of their land, the right to mortgage the land, and the right to transfer the land, but these texts are silent on the question of owners' responsibility to manage the lands they own sustainably. This is an inherent flaw of the Cameroonian land tenure system. Environmental concerns and, by extension, soil protection is thus not addressed by the Cameroonian legal framework on land tenure. One should expect to see clear and unambiguous provisions apportioning environmental responsibility to owners and users of the three land categories in Cameroon. However, the Preamble of Cameroon's Constitution indirectly imposes such environmental responsibility regarding land by providing that:

Every person shall have a right to a healthy environment. The protection of the environment shall be the duty of every citizen. The State shall ensure the protection and improvement of the environment.

Although these Constitutional pronouncements are relevant, their impact is less if compared to the direct provisions of specific legal texts on land. Given that land law contains no provision on the environmental responsibility of landowners, the land tenure law of Cameroon must be revised in order to impose such responsibility on landowners and users or to factor in or mainstream environmental protection concerns. This will go a long way to protect the soil.

In the absence of specific provisions establishing the environmental responsibility of landowners and users in the various regulatory and legislative texts governing land in Cameroon, Decree No. 2013/0171/PM of 14 February 2013 fixing modalities for carrying out ESIA seems to assign such environmental responsibility in connection with the use of land. This regulatory prescription ensures environmental responsibility of use of land by requiring the promoter of a project or an establishment to carry out an ESIA, under penalty of the laws and regulations in force. ${ }^{264}$

With respect to environmental protection, important elements of the assessment include the following: The presentation of the establishment, including the promoter, 
location, objectives, justification, facilities, operating processes, processing of raw materials, products, waste and effluents; the description and analysis of the environment of the establishment, including all the natural, human and sociocultural elements affected by the activities of the establishment; identification and analysis of environmental impacts; the field of intervention, including accounting with laws, regulations and policies, management, hygiene, health, safety and environment; the environmental and social management plan; and an information awareness programme, as well as the reports and minutes of public consultations held with the population, unions, opinion leaders and other organised groups concerned with the activities of the business. ${ }^{265}$

In fact, Article 5(1) provides that every promoter of a project subject to an ESIA must submit to the Minister of the Environment, in addition to the general file of the project a request for an ESIA including the sector of activity, and the terms of reference of the impact study accompanied by a project description and justification, with a focus on the preservation of the environment. Upon receipt of the request, the administration in charge of the environment will then give an opinion on the terms of reference of the impact assessment which include among others, the responsibilities and obligations of the promoter. ${ }^{266}$

Articles 5(6) and 15 further oblige every promoter of a project requiring ESIA to obtain a certificate of environmental compliance issued by the minister in charge of the environment to continue to operate, under penalty of the penalties prescribed by the legislation in force. Article 6 complements the provisions above by stipulating that no ESIA can be carried out without the approval of the terms of reference by the minister in charge of the environment. By the provisions of Article 13(1), the inter-ministerial committee of the environment must give its opinion on the ESIA files ${ }^{267}$ transmitted to it by the administration in charge of the environment. To ensure that the project promoter respects his environmental responsibility, the decree makes provision for monitoring and follow-up of the effective implementation of the environmental management by an administrative and technical supervision service of the competent administrations as per Article 16(1) and (2). The same Article in its (3) also requires the project promoter to produce a semi-annual report on the implementation of the environmental management plan at the Ministry of the Environment. Under Article 9, (1) the realisation of an ESIA must be done with the participation of the populations concerned through consultations and public hearings, in order to gather the opinions of the populations on the activity; (2) such public consultation consists of meetings during the impact assessment, in the localities affected by the activity; and (3) the

265 Article 4.

266 Article 5(3).

267 Containing the report of the environmental and social audit declared admissible; the assessment report of the environmental and social audit; and the evaluation report and the records of consultations and public hearings. 
public hearing is intended to publicise the impact assessment, record any opposition and allow the public to comment on the conclusions of the impact assessment. However, Article 12 excludes public consultation or hearings regarding the conduct of ESIA for activities of security or national defence. This exclusion constitutes a danger to both environment and people.

All the provisions above seek to establish and impute environmental responsibility on those carrying out projects which are likely to cause land degradation and, by extension, soil degradation. But we must be quick to add that such responsibility is for the promoters of large projects. What about those who carry out small projects or who acquire land to use for subsistence agriculture? Those who acquire land for human habitation whose projects have extremely negative impacts on the environment are not within the strict scrutiny of law in the same way as those carrying out subsistence agriculture such as the slash-and-burn and ankara systems that have been described above and which are proscribed by the 1994 Forestry Law.

In any event, the Arrête of $2016^{268}$ identifies and categorises those activities on land that require ESIA. The promoters of the activities mentioned above have the responsibility to ensure that such activities do not cause any environmental harm. An inherent weakness of this regulation concerns subsistence farming, such as slash-and-burn and ankara agricultural practices, which are mostly practised on small-scales. They are not taken into consideration by this regulation, which may be dangerous for soil health. Although these types of subsistence agriculture are usually practised on small scales, their total land surface area, when summed for all the farmers, is enormous and can lead to soil degradation. This is worsened by the fact that small-scale farmers have little or no incentive or motivation to practise sustainable soil management measures as their immediate concern is feeding their families. ${ }^{269}$ The livelihoods of almost all communities - if not all - depend on subsistence agriculture. This is enormous in terms of pressure on the soil and is enough reason for the inclusion of small-scale agriculture among the categories of agricultural projects which are subject to environmental impact assessment. For the purpose of soil protection, all agricultural projects whether practised on a small or large scale ought to comply with the law on environmental impact assessment. This may make sense from a theoretical angle but the critical question that must be answered is: Who should pay for the cost of the impact assessments given that small-scale farmers cannot afford to pay? Another important question is: Who should control the impact assessment process, given that small-scale farms add up to millions, dispersed all over the country? One way of resolving this is to make available extension administrative services at local levels to sensitise and educate local

268 See Arrêté No. 00001/MINEPDED of 8 February 2016 establishing the different categories of operations whose realisation is subject to a strategic environmental assessment or an environmental and social impact study.

269 See Ginzky et al. (2019: 4). 
famers on the importance of practising sustainable farming and to monitor and control their activities.

Moreover, it is not enough to establish the responsibility of landowners to manage their lands sustainably; incentives are critical tools that can encourage landowners to practise sustainable production methods on their lands. Furthermore, landowners can be educated on the linkages of their activities on land to soil degradation through sensitisation and capacity-building programmes, etc.

Legislation makes the state the primary landowner in Cameroon. ${ }^{270}$ While many of the communities occupying national lands claim customary rights or have some access rights to land and resources, these rights are poorly recognised in laws. Tenure insecurity encourages activities that offer more immediate returns from land rather than longterm returns from sustainable land management. The failure of public policies and land law to take into account traditional land rights constitutes a further source of land degradation. Deforestation sometimes is a means to secure land rights as clearance itself can establish proof of occupation and increase tenure security. The land tenure regime has not properly addressed tenure insecurity, especially on communities' lands that host much of the cultivable lands. Furthermore, most of the disjointed, segregated and scattered pieces of legislation were crafted without any consideration for environmental protection and, by extension, no soil protection provisions. The institutional framework for managing land and land-based resources such as minerals and forests is also weak. These challenges are worsened by improper land-use policy, which should instead guide the realisation of a balance between the many competing land uses. Poor land-use policies have led to continued degradation of land and soils.

Land tenure clarification, spatial planning, and mainstreaming of soil protection provisions are important elements of sustainable land use. If communities have undisturbed ownership rights to land, they will consider such rights not only as an economic commodity, but as a social and cultural resource that requires protection. In so doing, they will reduce unsustainable land practices, which are a great driver of soil degradation.

\subsection{Wildfires, hunting and cattle rearing}

As pointed out in Chapter two of this assessment, human-induced wildfires are another significant driver of soil degradation in Cameroon. Although there are fire management policies in Cameroon, strengthening capacities to prevent wildfires can help to protect soil. The 1994 Forestry Law proscribes fire. Article 14(1) forbids anyone from starting fire that is likely to cause damage to the vegetation of the national forest estate without prior authorisation. Article 80 prohibits hunting with the aid of fire. Article

270 See Section 1(2) of the Land Ordinance No. 74/1. 
154 punishes anyone who ignites a fire in a forest of the national domain, as provided for in Article 14 with a fine of CFA F5,000 to CFA F50,000 or imprisonment of 10 days, or both. Article 156 punishes with a fine of CFA F200,000 to CFA F1,000,000 or imprisonment of one month to six months, or both, anyone who makes a fire in a state forest, a protected or ecologically fragile area, in violation of Articles 14, 16(1) and (3), and 17(2) of the same law.

Furthermore, Decree No. 95/531/PM of 23 August 1995 to set the terms and conditions of applying the forest regime in Sections 6-8 recognises the role of the ministry of forestry staff to determine modalities for the safe control of fire, and the ministry of territorial administration and decentralisation to issue permits to start fires after consultation with local forestry staff. Joint MINFOF-community fire prevention and monitoring committees are supposed to be set up at local level, but they have hardly been effective owing to a lack of environmental concerns.

In the case of cattle rearing where the herders burn down both grassland and forests for fresh vegetation, there is a need for policies and strategies to address wildfires. Systems of intensive cattle rearing on ranches that have been successfully used in Indonesia are feasible options. ${ }^{271}$ Although such systems will need more financial inputs to enable adaptation with intensive livestock farming, they can greatly reduce pressure on soil.

\subsection{Conclusion}

An assessment of the sectoral legislations above reveals their strengths and weaknesses in terms of soil protection. Regarding their strengths, the sectoral legislations at least have some minimal soil protection relevance due to the fact that they make references to soil protection incidentally although, in most cases, indirectly. Notwithstanding the strengths of these legislations in terms of soil protection, this assessment also notes their weaknesses. For instance, sustainable land management in Cameroon seems challenging given that majority of the legal instruments for environmental and natural resources lack enabling instruments to complete and transpose the objective of the framework laws. Almost all legislation in Cameroon is incomplete regarding particular subject matter and this often provides that such issues are to be dealt with by decrees. These are the enabling instruments that further detail and complete the legislation. It usually takes months or years for such decrees to be established by the executive power. Such delays, which may be for political reasons, render the implementation of legislation difficult in practical terms. This is the case, for instance, with the current mining law. For the purpose of the effective implementation of a piece of legislation, parliament should always enact detailed and complete legislation like in common law

271 Epule et al. (2014: 412). 
countries where the enabling instruments do not exist. This way, the requirement of an enabling instrument can be bypassed. Better still, the text of law and its enabling instrument should be crafted at the same time, so as to facilitate the understanding and the immediate implementation of the law.

Our assessment of Cameroon's land tenure reveals that land access and land rights are a major determinant with regard to sustainable soil management. However, the plurality of land tenure - statutory and customary - is a major challenge that does not enhance soil protection. These drawbacks in the land law are a legacy of colonial history, which has been reinforced by modern post-colonial administration with the objective of exerting supremacy over vulnerable communities. After independence, the Government of Cameroon, like the colonial powers, continues to own most of the lands in Cameroon under the rubric of state lands and national lands. Colonisation has influenced and encouraged the following drawbacks: the non-legalisation of customary land titling; the fact that the state owns most of the land and the practice of land-grabbing and disposition of local communities' land by the state and its powerful allies (natural resource and agricultural investors, and the rich and influential elites); the challenges of land access and rights; and the high costs and cumbersome procedures involved with obtaining land titles. All these factors have serious implications for soil degradation. Furthermore, the various pieces of land legislation in Cameroon are completely devoid of soil protection provisions. On reading through the segregated and disjointed pieces of land legislation, one does not find any express references to the need to protect soil. Thus, land law in Cameroon is not only incoherent in terms of two systems co-existing and governed by segregated and ambiguous pieces of legislation; it is equally incomplete as it fails to address the need to protect soils.

Based on these revelations, our conclusion is that these legislations are devoid of any effective provisions for the protection of soils, especially as most of the legislations promote and encourage activities that drive soil degradation. There is therefore a need for legal reform to properly address soil protection. One way is the formulation of a comprehensive and authoritative framework legislation for land management as well as the establishment of a national environmental protection agency that will supervise all land-use related activities in the country. Furthermore, secured landownership rights can favour the adoption of sustainable soil management practices. In fact, security of tenure is important for the adoption of land conservation practices. A combination of short-term and long-term policy measures that offer incentives for sustainable soil management practices or land conservation, including enhanced security of tenure, government targeting programmes and other policies that reduce household poverty and improve access to education, both formal and informal, is critical. 


\subsection{Positive lessons learnt and opportunities for soil protection}

Regarding the existing enabling legal environment scattered provisions (express and implied) in various pieces of legislation such as the Constitution, Framework Law on Environmental Management, and sectoral laws in agriculture, mining, forestry, water, land tenure. Specific legislation on the protection of soils and subsoils (Decree No. 2011/2584/PM of 23 August 2011 on the modalities for the protection of soils and subsoils which requires any activity relating to the exploitation of the soil to be carried out in a manner that avoids or reduces erosion of soils and desertification), but with the limitation that it is not comprehensive enough. Information, public participation, education, policy advocacy and planning, as well as monitoring of trends and impact of interventions in sustainable soil management, are central to the success of efforts to foster protection of soils. Information and communication technologies, the media, networks and extension services are vital components of improved information systems to enhance sustainable soil management. There are scant policy and legal provisions on these interventions in the 1996 Framework Law on Environmental Management, the ESIA decree and other sectoral legislation and their implementation is weak.

Soil degradation interventions should be designed to ensure their sustainability. The effective involvement of small-scale famers and local communities should be required in land and soil degradation control activities. Their knowledge, skills and adaptive capacities are invaluable in ensuring sustainable land and soil management practices. This is well recognised in the 1996 Framework Law on Environmental Management, but the harnessing of local knowledge and skills and the empowerment of local communities through increased capacity-building that is linked to achieving tangible results is not a reality in Cameroon. Community regulation on pesticides and fertilizers - the Common Provisions on the Homologation of Pesticides in the CEMAC Zone aims to bring together experiences and expertise of the member states for the evaluation and homologation of pesticides. The objective is to ensure their rational and judicious use, as well as the protection of human health and the environment; and to oversee experimentation, authorisation, importation, exportation, transportation, transit, stocking, marketing, use, control and elimination of active materials and formulated products of pesticides within the states of the CEMAC zone. Regarding industrial development, in the absence of specific legislation governing the industrial sector in Cameroon, the sector today is regulated through a plethora of disjointed and dispersed pieces of regulatory instruments.

Given the cross-cutting nature of soils and the ever-present threat of degradation, it is pertinent that strong and well-functioning institutional frameworks are put in place to coordinate the formulation and implementation of related policies and programmes and to ensure that they are adequately mainstreamed into relevant national sectoral 
development plans, policies, strategies and legislation. A good number of government ministerial departments (MINADER, MINDCAF, MINEPDED, MINEPAT, MINDUH, Ministry of Trade, MINMIDT, MINRESI, MINEPIA, etc.), whose functions or roles are relevant to soil protection and which are supported by decentralised entities, are in place, albeit with weak powers. Government ministerial departments are supported by public and para-public institutions working in the area of soil protection, such as IRAD, ANAFOR (National Forestry Development Agency) ${ }^{272}$, MIDENO (North West Development Authority ${ }^{273}$ ), the Inter-Ministerial Committee for the Environment, the National Consultative Commission for the Environment and Sustainable Development, and the National Council for Planning and Sustainable Development of the Territory. Examples of further support bodies are development partners via project sponsorship, such as the GIZ (German Agency for International Cooperation) and the AFD (French Development Agency), backed by carefully drafted and signed project agreements.

Sustainable soil management and soil protection are complex issues that need an integrated approach to achieve meaningful and sustainable results. The Inter-Ministerial Committee for the Environment, the National Consultative Commission for the Environment and Sustainable Development, the National Council for Planning and Sustainable Development of the Territory are relevant in this respect, but the functioning of these initiatives are weak.

\subsection{Negative lessons learnt}

Although access to environmental information, public participation and access to justice in Cameroon is guaranteed by the 1996 Framework Law on Environmental Management and other relevant legislation with regard to sustainable soil management, public participation and access to information is not sufficiently implemented in Cameroon. In fact, information on soil is often inadequate, out-dated, not available in digital format and not referenced geographically. The danger of soil degradation in the country is little known to the general public and is underestimated by those who are

272 ANAFOR was created in 2002 following the restructuring of the former National Forestry Development Agency, ONADEF. It is in charge of supporting stakeholders (collectivities, but also private sectors and communities) in reforestation initiatives. Officially, ANAFOR is in charge of implementing the national programme for the development of private and community forestry plantations. See the REDD desk website, at https://theredddesk.org/countries/actors/nationalforestry-development-agency-cameroon, accessed 11 September 2019.

273 MIDENO acts on behalf of the Government of the Republic of Cameroon in the North-West Region as the supervisor of development policy and providing a budgetary, financial and technical mechanism for development projects. See the North-West Region's web portal, at http://www.all-about-cameroon.com/cameroon-north-west-development-authoritymideno.html, accessed 11 September 2019. 
informed, and therefore does not constitute an immediate concern. There is also weak implementation of the scant policy and legislative provisions in the 1996 Framework Law on Environmental Management, the ESIA decree and other sectoral legislation regarding environmental information, public participation and access to justice in Cameroon.

Sectoral activities such as agriculture, mining, demographic growth, industrial development are the main drivers of soil degradation. Sectoral pieces of legislation on these activities are devoid of any specific and effective provision for the protection of soils, especially as most of the legislation promotes and encourages activities that drive soil degradation. Legislation on mining contains provisions relevant to soil protection, but this law, like most pieces of legislation in Cameroon, is paralysed because of the lack of enabling instruments.

Regarding the role of foreign investors in the mining sector in Cameroon, we discovered that they are not usually attentive to the concerns of environmental protection as they care little about reinstating or rehabilitating exploited sites. The degraded sites lead to soil degradation. Such investors use chemical products such as mercury that are unhealthy for the environment in general and soils in particular as it pollutes the water used by the local people and destroys the attendant biodiversity, including soils. Regarding industrial development, Cameroon presently has no specific legislation governing the industrial sector. One finds effluent or liquid and gaseous discharge of industrial origin, treated or untreated, discharged directly or indirectly into the environment in some major cities such as Douala. This is harmful to soil health. This sector constitutes a further danger to the soils given that industrialisation is one of the pillars and the growth engine which the government intends to rely on to achieve its Vision 2035. Despite the symbiotic relationship between soil and climate change, both international and national politics on climate change have paid little attention to the importance of soil as a natural solution when combating climate change. In fact, the symbiotic relationship between soil and climate change has not been captured by legislation. This is not surprising since Cameroon has no climate change legislation that recognises the impacts of climate change on soil and the critical role that soil plays in mitigating climate change. This is clear proof of the inadequate political will to give more attention to the relevance of soils in fighting climate change.

Most agricultural projects are associated with soil degradation caused either by the misuse of chemical products (pesticides and fertilizers) or unsustainable farming methods, such as the slash-and-burn, bushfire and ankara methods practised by most local communities across the country. Domestic legislation on water and soil protection and the CEMAC Community Regulation on pesticides and fertilizers are poorly implemented. In addition, legislation on ESIA does not address the slash-and-burn or the ankara agricultural methods. Legislation on bushfire also suffers from implementation problems. Agricultural scientific data and information on sustainable soil management are not made available to farmers, and more particularly not to small-scale farmers, who 
continue to indulge in unsustainable agricultural practices that are detrimental to soil health.

Regarding current land tenure in Cameroon, colonial legislation continues to influence and encourage the following drawbacks: the non-legalisation of customary land tenure; the fact that the state owns all lands and the practice of land grabs and dispossession of local communities' land by the state and its powerful allies (agricultural investors, and the rich and influential elites); the challenges of land access and rights and the high costs and cumbersome procedures involved in obtaining land titles or land registration. All these factors have serious implications for sustainable soil management.

One of the difficulties underpinning soil protection in Cameroon is the absence of a specific law applicable to this critical resource. This is not to say soil is unregulated, but the plethora of laws spread across a wide range of areas and sectors render implementation challenging. This becomes even more intricate because of contradictions in sectoral laws, especially concerning land use and the authority of the state; and duplication of institutional roles, especially for the ministries and community involvement. Such duplication seems to promote conflict between sectoral ministries rather than achieve a coordinated approach to protect the soil. Other core impediments for effective sustainable soil management in Cameroon are institutional and organisational deficiencies. National institutions both at the level of central administration and decentralised entities are charged with the responsibility of law implementation in general and the implementation of laws relating to soil protection in particular. One big challenge, however, is the organisational deficiencies stemming from the challenges of the decentralisation process wherein the central administrative units are reluctant to transfer the necessary resources and competencies to the decentralised entities (regions and councils) to enable them to carry out their functions, including the soil management function, properly. Even where resources and competencies are transferred, the institutional arrangements for such transfers are unclear. Unlike other countries in Africa, for instance, those with decentralised entities having legislative powers, decentralised entities such as regions and councils in Cameroon do not have powers or competence to make laws. Rather, the central administration, which is also slow to act, delegates only law implementation powers to the decentralised entities. Thus, while comprehensive soil legislation is absent, the limited legislation on a matter that is central is only poorly implemented in the country, thus rendering soil protection difficult within the entire administrative set up of the country.

\subsection{Recommendations}

Given the potential of doubling production in terms of agriculture and natural resources exploitation, there will be increased pressure on soils, necessitating effective 
soil protection legislation. Throughout this assessment, it has been established that soil is the bedrock of all-natural resources. For this reason, the following recommendations are proffered: Although the Constitution implicitly mentions soil when it speaks of natural resources, a specific constitutional provision addressing soil protection should be enacted. Thereafter, parliament should proceed to craft a comprehensive and coherent piece of legislation that encapsulates all the specific provisions in framework and sectoral laws that relate to or have implications for sustainable soil management.

In order to craft overarching legislation for soils, the following aspects should be considered: Crafting a detailed and comprehensive soil protection law to facilitate understanding and an informed, immediate and effective implementation of such law; including soil management in the academic curricula at the elementary level up to university stage, or at least mainstream soil management issues in teaching at all levels; passing on soil information to small-scale farmers and the part of the population that does not have access to academic education, which should be done through sensitisation and carefully thought-out capacity-building programmes; considering, and mainstreaming soil legislation to all important soil and soil-related governance benchmarks such as contracting processes for soil exploitation activities, corruption, transparency, accountability in soil exploitation arrangements and contracts; involving relevant stakeholders who have fervent concerns about soil protection, such as non-governmental organisations, civil society organisations and environmental protection institutions, in the crafting of soil legislation; improving institutional arrangements through more effective decentralisation consisting of the actual transfer of power and competencies and the necessary resources from the central to decentralised territorial entities, in order to overcome the challenge of 'no one being in charge'. This requires strong political will from the powers-that-be.

Moreover, obtaining clarity from the existing sectoral legal and institutional dispensation is important. A specific soil protection law will provide certainty and clarity on measures of applicability of such provisions. A first step in this direction will be to consolidate all applicable laws to soil. The revision of the different laws on the institutional organisation of the different ministries - mainly the provisions that are at the origin of conflict - is critical. Ensuring legal and institutional certainty and clarity may require the creation at the level of the prime ministry of an inter-ministerial committee in charge of coordinating decision-making related to land-use to ensure effective compliance to the different sectoral laws or simply reinforce the role of coordination of government actions already being ensured by the prime minister, but with particular emphasis on soils as this resource is critical for human survival. Given that Cameroon is characterised by different soil types, it should consider viewing legislation as zonal, addressing specifically the different types of soils, while increasing the sanctions for violators of environmental and soil legislation, which have hitherto been minimal and do not have strong deterrent effects. 
Soil protection can be enhanced in the following ways: By adopting a forest strategy including afforestation and reforestation programmes; by formulating an integrated multi-use landscape strategy for restoration of degraded landscapes with a specific focus on soil. This entails taking into consideration all land uses that ensure the participation of all land users; by developing a strategy that engages development partners and funding organisations for projects on sustainable soil protection; by developing a programme of compensation through soil restoration projects; by developing programmes that are geared towards the sensitisation of farmers on the danger of using non-homologated phytosanitary products, chemicals and pesticides and implementing other unsustainable farming practices such as slash-and-burn, bushfires and the ankara system; by updating the National Environment Management Plan (NEMP) and rethinking the setting of standards for restoring degraded lands, as a matter of urgency. NEMP has no standards to be achieved for restoration of degraded sites and this is probably a huge weakness because one can never ascertain whether restoration has been effectively achieved to reduce soil degradation.

In terms of improvement of enforcement, monitoring, and access to environmental information it remains key to foster collaboration, cooperation and synergies among centralised and decentralised territorial entities for more effective enforcement of laws and policies through a multi-level committee of representatives of central and decentralised administrative entities. Enhancing access to environmental information and public participation in decision-making are crucial ingredients for environmental and soil enforcement mechanisms. This can be done by elaborating an access to information law that gives everyone the right of access to information held by public bodies and relevant private bodies expeditiously and gratuitously. Public bodies and relevant private bodies must proactively publish information and any refusal to disclose information should be subject to appeal. Of course, disclosure should be subject to security and strategic restrictions. The improvement of government structures charged with monitoring and enforcement of environmental and soil laws and policies is necessary, just as the enhancement of the implementation of existing ESIA measures by engaging independent environmental assessors.

In terms of the improvement of land rights it is important to reduce the multiplicity of legal instruments and requirements on access to land by means of harmonisation and consolidation of the scattered and disjointed pieces of legislation on land tenure in a single land act. Moreover, the recognition of customary laws relating to land tenure must be reflected in modern legislation, or at least modern legislation should ensure that procedures for access to land are comprehensible and accessible to all social groups. Preferably, a land act that harmonises and consolidates the segregated and scattered pieces of legislation on land tenure should be enacted in Cameroon. Such a land act should recognise customary land rights and accord such rights legal protection, and such rights should be considered as a category of private property. This may be accommodated in the ongoing land tenure reform process. 
Regarding the control of foreign investors it may be advisable to enact laws imposing an environmental degradation tax, such as a pollution tax; to legalise the certification of commodities whose production or importation are likely to lead to soil degradation; to put in place reforms that limit the amount of land acquired by foreign investors; to commit foreign investors to social responsibility, responsible business or corporate citizenship so as to avoid social conflicts with communities. This is a self-regulating paradigm that helps companies or investors to be socially accountable to the public and commits to corporate environmental responsibility so as to avoid environmental degradation generally and soil degradation specifically.

Incentive mechanisms should be developed that encourage farmers to invest in degraded lands in order to avoid further pressure on such lands by providing them with manure free of charge and granting interest-free loans. Governance and institutional capacity should be enhanced with adequately trained and equipped human resources, especially at decentralised level to ensure effective implementation of monitoring and control activities. Alternative income-generating activities should be provided to small-scale farmers in order to reduce pressure on soil.

The Sub Regional Community Secretariat should urge governments to observe and implement community regulations on soil protection, for instance, the pesticide regulation. Given that climate change is a main driver of soil degradation and that there is a corresponding crucial role of soil in combating climate change through its carbon storage function, both climate change and soil legislation should recognise this symbiosis and mainstream it in climate change and soil legislation.

The detrimental impacts of the misuse of chemical products (pesticides and fertilizers) and unsustainable farming methods (slash-and-burn, bushfire and the ankara method) can be averted by developing policies that are geared towards the sensitisation of farmers about the danger of using non- homologated chemicals, phytosanitary products, pesticides and unsustainable farming practices. Thus, it may be advisable to put a moratorium on lands in place, in order to prevent activities that degrade the soil. There is a need for data on soil degradation to be made available to the general public, especially small-scale farmers and for the involvement of science institutions in the model legislation. Information on the status of soil and appropriate measures to achieve sustainable soil management are critical and should be integrated into curricula at all levels of education.

Through a mix of soil conservation techniques such as better tree and pasture management, simple and low-cost farmer-led innovations and technologies can help to achieve sustainable land management and farming systems needed to combat land and soil degradation. Building on and reinforcing these innovations and technologies with expertise and resource support can enhance achievement of better results.

One important challenge to deal with regarding soil protection is obtaining the buy-in of politicians. Soil degradation and its effects need continuous urgent attention, carefully backed up by appropriate, comprehensive and coherent policy, and a legal and 
institutional framework. A policy and legal framework that defines the activities to be taken and those not to be taken, as well as the institutions and actors and their respective roles, is the foundation of any meaningful step towards sustainable soil management. However, a strong political will is also required to enable the crafting and implementation of such a framework. Any effective measure to manage soils sustainably is contingent on the government's political will to facilitate the measure. It is crucial that politicians buy into and address the political, social and economic importance of soils. The political and socioeconomic exigencies of the population, as highlighted in the country's GESP, National Rural Sector Development Strategy and related documents, are critical factors that can trigger the political will of the government to initiate policy and the legal and institutional changes necessary to enhance sustainable soil management; and to implement good governance for the success of such a policy, as well as legal and institutional changes. There is thus the need for a strong political will to fast track the revision of sectoral legislation, policies and institutional frameworks to include specific soil protection provisions. However, the availability of a comprehensive and coherent policy and a legal and institutional framework does not guarantee successful implementation unless there is also a corresponding political will to ensure the enforcement of the laws and policies. In the absence of political will, the initiative would remain a paper-based idea. The single most important prerequisite for sustainable soil management is thus the political ambition of the state to initiate policies and implement actions on the ground. The political, social and economic relevance of soils are critical levers that can secure the buy-in of politics.

Entrenched vested interests often favour activities that drive soil degradation. To respond effectively to this challenge, a strong political commitment is critical. Buy-in of politics can be ensured by resorting to legislative lobbying and advocacy by identifying politicians, legislators and decision-makers who are sympathetic to soil protection concerns, and who are willing to collaborate, but also by identifying those officials who have opposing views. Sympathetic individuals will then be able to assist advocates in widening the network of policy supporters by recommending others to call, to write to and to lobby. Such contacts can be secured through group or individual meetings or briefings designed to present facts and analysis of proposed legislation. Such facts and proposed legislation should clearly and unambiguously present and demonstrate the political, social and economic importance of soils. Whether advocates meet, call or write to those who support or oppose the advocacy goal, they need to be courteous and respectful towards parliamentarians, government officials and policymakers and consider the importance of long-term relationships.

Public hearings, discussions and forums may also be explored by those leading the advocacy efforts. Since there is strength in numbers, forming alliances with other stakeholders advocating for soil protection can bring more pressure to bear on government officials, legislators and policymakers - which may produce positive outcomes. Network alliances can be formed with the following categories of stakeholders: 
legislators, government officials and policymakers who are already in favour of the project; recognised experts in the field; credible celebrities who are sympathetic to the issue; professionals or other organisations concerned with the issue or with the population; supportive community members and investors, as well as others who understand the issue; people who work in organisations offering services aimed at promoting the policy; actual or potential beneficiaries of the policy; and even those who may disagree with the policy. Those advocating and conducting lobbies need to put in place a single coordinating body at the core of the advocacy and lobby effort and be specific and clear about the policy. A well-defined message is easier to pass on to allies, as it is easier for them to understand, and less likely to be misstated. Such a message is easier for government officials, legislators, policymakers and the public to understand, especially if they are unfamiliar with the issue; and it is more likely to be received favourably by government officials, legislators and policymakers, especially if it targets some specific action. The media is also a critical tool in the advocacy campaign to obtain the buy-in of politics.

\section{References}

Alemagi, D., V.A. Sondo \& J. Ertel, 2007, "Constraints to environmental impact assessment practice: A case study of Cameroon". Journal of Environmental Assessment Policy and Management 9 (3), 357, at https://www.worldscientific.com/doi/10.1142/S1464333207002809, accessed 9 May 2019.

Amin, G.F. \& I.R. Jaha, 2016, Land grabs in Africa: Economic imperialism? Critical contributions to a new paradigm. Saarbrücken: LAP LAMBERT Academic Publishing.

Ayonghe, S.N., 1999, "Statistical analysis of palaeo climatic changes in Cameroon and projections into the 21 st Century; causes of observed trends and predictable effects on biodiversity within the Central African Region". In: Nkwi P.N. \& D.A. Mbah (eds), Conserving and managing biodiversity in Central Africa: Global challenges and local solutions. Yaoundé: Cameroon Academy of Sciences.

Belaunde, S., M. Cortes, J. Hogstad, E. Ku, K. Nascimento \& L. Trzcinski, 2010, Land, legitimacy and governance in Cameroon. New York: Institute for Research and Debate on Governance \& Columbia University School of International and Public Affairs, at http://www.institut-gouvernance.org/docs/sipa_cameroon_land_legitimacy_governance-2010.pdf, accessed 23 January 2021.

Bella, N., 1993, “Cameroun: De L'encouragement des naissances a la maitrise de la fécondité causes et conséquences de l'evolution observée". African Population Studies, 20, at http://aps.journals.ac.za/pub/article/download/419/376, accessed 4 August 2019.

Boer, B.W., H. Ginzky \& I.L. Heuser, 2016, "International soil protection law: History, concepts and latest developments”. In: Ginzky, H., I.L. Heuser, T. Qin, O.C. Ruppel \& P. Wegerdt (eds), International yearbook of soil law and policy. Cham: Springer, 49.

Brevik, E.C., 2012, "Soils and climate change: Gas fluxes and soil processes". Soil Horizons 53 (4), 12.

BUCREP / Bureau Central des Recensements et des Études de Population, 2010, La population du Cameroun en 2010: Rapport de presentation des resultats definitive. Yaoundé: République du Cameroon. 
Chapman, S., M. Wilder \& I. Miller, 2014, "Defining the legal elements of benefit-sharing in the context of REDD+". Carbon \& Climate Law Review 8 (4), 270.

Costenbader, J. (ed.), 2009, Legal frameworks for REDD: Design and implementation at the national level. Gland: IUCN.

Cowie, L.A., B.J. Orr, V.M. Castillo Sanchez, P. Chasek, N.D. Crossman, A. Erlewein, G. Louwagie, M. Maron, G.I. Metternicht, S. Minelli, A.E. Tengberg, S. Walter \& S. Welton, 2017, "Land in balance: The scientific conceptual framework for land degradation neutrality". Environmental Science \& Policy 79, 25.

CPF / Collaborative Partnership on Forests, 2008, Strategic framework for forests and climate change: A proposal by the Collaborative Partnership on Forests for a coordinated forest-sector response to climate change, at https://bit.ly/3pzm6db, accessed 4 August 2019.

Dashaco, J.T. \& B.G.M. Tarh, 2018, "Understanding the blueprint of environmental impact assessment for developing countries: The headway and impediments in Cameroon". International Journal of Advanced Research 6 (5), 194.

Denier, L., S. Korwin, M. Leggett \& C. MacFarquhar, 2014, The little book of legal frameworks for $R E D D+$. Oxford: Global Canopy Programme.

Dobgima, A., 2008, Advanced regional geography for Cameroon schools. Yaoundé: The Leader Print Publishers.

Ekane, D.N. \& P.M. Oben, 2001, "Biochemical indicators of marine pollution in the Douala Lagoon and Limbe Estuary". In: Lambi, C.M. (ed.), Environmental issues: Problems and prospects. Bamenda: Unique Printers, 119.

Elias, T.O., 1971, Nigerian land law. London: Sweet and Maxwell, London.

Epule, T.E., P. Changhui, L. Laurent \& C. Zhi, 2014, "Policy options towards deforestation reduction in Cameroon: An analysis based on a systematic approach". Land Use Policy 36, 405.

FAO / Food and Agriculture Organization of the United Nations, 2009, Environmental impact assessment and monitoring in aquaculture: Requirements, practice, effectiveness and improvements. FAO Fisheries and Aquaculture Technical Paper No. 527, Rome: FAO.

FAO / Food and Agriculture Organization of the United Nations, 2015, Soil degradation. Rome: FAO, at http://www.fao.org/soils-portal/soil-degradation-restoration/it/, accessed 21 January 2021.

FAO / Food and Agriculture Organization of the United Nations \& ITPS / Intergovernmental Technical Panel on Soils, 2015, Status of the world's soil resources (SWSR): Main report. Rome: FAO.

Fogwe, Z.N., F. Ndifor, C.M. Lambi \& R.M.E. Etame, 2001, "Industrial water pollution: the case of the Ndogbong Industrial District, Douala (Cameroon)". In: Lambi, C.M. (ed.), Environmental issues: Problems and prospects. Bamenda: Unique Printers, 7.

Forest Carbon Partnership Facility Cameroon, 2013, Readiness Preparation Proposal (R-PP). Yaoundé: Forest Carbon Partnership Facility Cameroon.

Fraser, E. \& F. Mousseau, 2016, Background bullying: The role of the US Government in the Herakles Farms' land grab in Cameroon. Oakland: Oakland Institute, at https://www.oaklandinstitute.org/sites/oaklandinstitute.org/files/backroom-bullying-final.pdf, accessed 13 May 2019.

Fru, V.N., undated, Land grabbing: The case of Herakles Farms in Cameroon. Buea: International Centre for Environmental Education and Community Development (ICENECDEV), at https://www.icenecdev.org/Land-Grabbing-in-Cameroon.pdf, accessed 24 January 2021.

GEF / The Global Environment Facility, 2007, Building Cameroon's capacity to ensure synergy between environmental conventions. Yaoundé: The National Coordination of the ANCR-NCSA process.

Ginzky, H., O.C. Ruppel, R. Kibugi \& W. Engelberg, 2019, Implementing land degradation neutrality in Africa: Means, legal instruments and institutional challenges. Outcome summary document of 
a workshop organised in coorperation between the German Environment Agency (UBA), the Konrad-Adenauer Foundation - Climate Policy and Energy Security Program for Sub-Saharan Africa, the GIZ and University of Nairobi, Nairobi, Kenya, 14 to 15 August 2018, at https://www.umweltbundesamt.de/sites/default/files/medien/2875/dokumente/nairobi_outcome_document.pdf, accessed 31 January 2021.

Hamidov, A., K. Helming, G. Bellocchi, W. Bojar, T. Dalgaard, B.B. Ghaley, C. Hoffmann, I. Holman, A. Holzkämper, D. Krzeminska, S.H. Kværnø, H. Lehtonen, G. Niedrist, L. Øygarden, P. Reidsma, P.P. Roggero, T. Rusu, C. Santos, G. Seddaiu, E. Skarbøvik, D. Ventrella, J. Żarski \& M. Schönhart, 2018, "Impact of climate change adaptation options on soil functions: A review of European case-studies". Land Degradation and Development 29 (8), 1.

Hannam, I. \& B. Boer, 2004, Drafting legislation for sustainable soils: A guide. Gland: IUCN.

IOM / International Organization for Migration \& UNCCD / United Nations Convention to Combat Desertification, 2019, Addressing the land degradation - migration nexus: The role of the United Nations Convention to Combat Desertification. Geneva: IOM.

Kang, A., 2013, Legal, institutional and technical framework for lake/wetland protection. Briefing Paper, New Delhi: Centre for Science and Environment.

Kwame, S.A., 2006, "Managing wetlands in Accra, Ghana”. African regional workshop: Cities, ecosystems and biodiversity. Nairobi, Side Event at the Africities Summit.

Lambi, C.M. (ed.), Environmental issues: Problems and prospects. Bamenda: Unique Printers.

Lang, M.K., 2017, "Land disputes between the catholic church and indigenes of Weh Fondom, 19571996”. Ghana Social Science Journal 14 (1), 109.

Lemmens, M., 2010, "Statutory versus customary land ownership conflicts in Cameroon”. GIM International 3 December 2010, at https:/www.gim-international.com/content/article/land-ownership-conflicts-in-cameroon, accessed 3 June 2019.

Mbu, A.P., 2014, Regional geography for Cameroon. Buea: Trinity Ventures Printing and Publishing.

McLeman, R., 2017, Migration and land degradation: Recent experience and future trends. Global Land Outlook Working Paper, at https://knowledge.unccd.int/sites/default/files/201806/8.\%20Migration\%2Band\%2BLand\%2BDegradation__R_McLeman.pdf, accessed on 9 April 2020 .

Ministry of the Environment and Nature Protection \& FCPF / The Forest Carbon Partnership Facility, 2008, Readiness Plan Idea Note (R-PIN), Cameroon. At https://www.forestcarbonpartnership.org/system/files/documents/Cameroon_R-PIN_07-31-08.pdf, accessed 31 January 2021.

Ministry of the Environment, Protection of Nature and Sustainable Development, 2018, The national strategy for reducing emissions from deforestation and forest degradation, sustainable management of forests, conservation of forest and enhancement of carbon stocks, (National REDD + Strategy). Final Version. Yaoundé: Government of Cameroon.

Munge, S.P., 2011, The concept of equality and access to land: The case of the anglophone regions of Cameroon. PhD Thesis, University of Buea.

Nchangvi, S.K., 2010, Systems analysis in biogeography for advanced learners. Yaoundé: Grassroot Publishers.

Ndi, F.A., 2017, "Land grabbing, local contestation, and the struggle for economic gain: Insights from Nguti Village, South West Cameroon". SAGE Open, 1, at https://journals.sagepub.com/doi/pdf/10.1177/2158244016682997, accessed 13 May 2019.

Ndzeidze, S.K., 2008, Detecting changes in a wetland: Using multi-spectral and temporal Landsat in the Upper Noun Valley Drainage Basin-Cameroon. Master of Science, Oregon State University.

Neba, A.S., 1987, Modern geography of the Republic of Cameroon. Second edition, Camden: Neba Publishers. 
Ngoh, V.J., 1996, History of Cameroon since 1800. Limbe: Pressbook.

Ngwafor, E.N., 1996, Family law in anglophone Cameroon. Regina: University of Regina Press.

Ngwoh, V.K., 2019, "Cameroon: State policy as grounds for indigenous rebellion. The Bakweri land problem, 1946-2014”. Conflict Studies Quarterly 27, 39.

Ngwome, G.F., 2018, The contribution of forest to climate change mitigation under the REDD+Initiative in Cameroon: The search for an appropriate legal framework. $\mathrm{PhD}$ Thesis, University of Yaoundé.

Nhantumbo, I. \& C. Marisa, 2015, REDD + for profit or for good? Review of private sector and NGO experience in REDD+ projects. Natural Resource Issues No. 30, London: IIED.

Njoh, D.B., T. Feldt, C. Seeger, N. Dittrich, H. Karg, E. Gawum, A. Witte \& R. van Veenhuizen, 2018, Urban and peri-urban agriculture in Bamenda: A policy narrative. For SHUMAS UrbanFoodPlus RUAF Foundation and the Bamenda Multi-Stakeholder Platform, at http:/www.urbanfoodplus.org/fileadmin/user_upload/Publications/Policy_Narrative_Bamenda_2018.pdf, accessed 3 July 2019.

Olimova, S. \& M. Olimov, 2012, Environmental degradation, migration, internal displacement, and rural vulnerabilities in Tajikistan. Grand-Saconnex: International Organization for Migration (IOM), at https://publications.iom.int/system/files/pdf/tajikistan2012envreport_eng.pdf, accessed 9 April 2020.

Orr, B.J., L.A. Cowie, V.M. Castillo Sanchez, P. Chasek, N.D. Crossman, A. Erlewein, G. Louwagie, M. Maron, G.I. Metternicht, S. Minelli, A.E. Tengberg, S. Walter, \& S. Welton, 2017, Scientific conceptual framework for land degradation neutrality. A report of the science-policy interface, Bonn: United Nations Convention to Combat Desertification (UNCCD).

Pareek, N., 2017, "Climate change impact on soils: adaptation and mitigation". MOJ Ecology \& Environmental Science 2 (3), 136.

Pollini J., 2015, Shifting cultivation, gender and REDD + in Cameroon and the Democratic Republic of Congo. Washington DC: USAID-supported Forest Carbon Markets and Communities (FCMC) Programme.

Republic of Cameroon, 2012, National biodiversity strategy and action plan. Version II. Yaoundé: MINEPDED.

Republic of Cameroon, 2013, Strategy paper of the education and training sector 2013-2020. Yaoundé: MINESEC.

Republic of Cammeroon, 2015, Intended nationally determined contribution (INDC). At https://www4.unfccc.int/sites/ndcstaging/PublishedDocuments/Cameroon\%20First/CPDN\%20CMR\%20Final.pdf, accessed 31 January 2021.

Sanz, M.J., J. de Vente, J.-L. Chotte, M. Bernoux, G. Kust, I. Ruiz, M. Almagro, J.-A. Alloza, R. Vallejo, V. Castillo, A. Hebel \& M. Akhtar-Schuster, 2017, Sustainable land management contribution to successful land-based climate change adaptation and mitigation. A report of the SciencePolicy Interface. Bonn: United Nations Convention to Combat Desertification (UNCCD).

Sone, P.M., 2012, "Conflict over landownership: The case of farmers and cattle graziers in the NorthWest Region of Cameroon". AJCR 2012, 1, at https://www.accord.org.za/ajcr-issues $/ \% \mathrm{EF} \% \mathrm{BF} \% \mathrm{BC}$ conflict-over-landownership/, accessed 25 July 2019.

Tafon, R. \& F. Saunders, 2019, "The politics of land grabbing: State and corporate power and the (trans)nationalization of resistance in Cameroon". Journal of Agrarian Change 19, 41.

Tajoche, T., 2008, Cameroon history in the 19th and 20th centuries. Buea: Education Book Centre.

Tamasang, C.F., 2014, "Constructing synergies for the conservation and wise use of wetlands in the central African sub-region: Legal and institutional pathways". Revue Africaine de Droit Public (RADP) $3(5), 25$. 
Tamasang, C.F. \& G.F. Ngwome, 2018, “REDD+ implementation in Cameroon's environmental law: The role of indigenous peoples and local communities". In: Ruppel, O.C. \& E.D. Kam Yogo (eds), 2018, Environmental law and policy in Cameroon - Towards making Africa the tree of life. BadenBaden: Nomos, 934.

Tande, D. (ed.), 1999, The Bakweri land problem and the privatization of the Cameroon Development Corporation (CDC): The Internet Debates (August-December 1999). At https://bit.ly/2Yu2ZFN, accessed 31 January 2021.

Tassah, I.T., 2019, Land cover dynamics and agricultural intensification in Momo Division, NorthWest Region of Cameroon. Unpublished PhD Thesis, University of Yaoundé I, Cameroon.

Taza-Asaba, J., 2013, Environmental monitoring and compliance methodology developed through lessons learnt from oil \& gas companies in Cameroon. Calgary: IAIA13 Conference Proceedings 33rd Annual Meeting of the International Association for Impact Assessment, 13-16 May 2013, at https://conferences.iaia.org/2013/pdf/Final\%20papers\%20review\%20process\%2013/Environmental\%20Monitoring\%20and\%20Compliance\%20Methodology.pdf, accessed 16 May 2019.

Tchoffo, B., 2009, "Shifting cultivation and climate change in Cameroon: What role environmental impact assessment play?". Presentation at the $29^{\text {th }}$ Annual Conference of the International Association for Impact Assessment, Accra International Conference Center, Accra.

UN Economic Commission for Africa, 2007, African review report on drought and desertification. Fifth Meeting of the Africa Committee on Sustainable Development (ACSD-5) Regional Implementation Meeting (RIM) for CSD-16 Addis Ababa, 22-25 October 2007.

Yahmed, B.D., N. Houstin \& C. Segnobos, 2007, Atlas of Cameroon. Yaoundé: Les Editions J.A.

Zomer, R.J., D.A. Bossio, R. Sommer \& L.V. Verchot, 2017, Global sequestration potential of increased organic carbon in cropland soils. Scientific Report 7, 15554, at www.nature.com/scientificreports/, accessed 4 June 2019. 